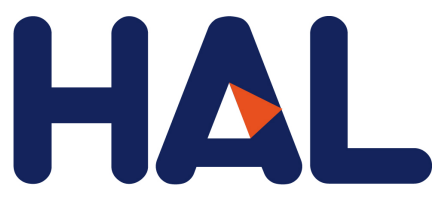

archives-ouvertes

\title{
A multi-scalar study of the long-term reactivity of uranium mill tailings from Bellezane site (France)
}

M. Ballini, C. Chautard, J. Nos, V. Phrommavanh, C. Beaucaire, C.

Besancon, A. Boizard, Michel Cathelineau, C. Peiffert, T. Vercouter, et al.

\section{- To cite this version:}

M. Ballini, C. Chautard, J. Nos, V. Phrommavanh, C. Beaucaire, et al.. A multi-scalar study of the long-term reactivity of uranium mill tailings from Bellezane site (France). Journal of Environmental Radioactivity, Elsevier, 2020, 218, pp.106223. 10.1016/j.jenvrad.2020.106223 . hal-02735745

\section{HAL Id: hal-02735745 \\ https://hal.univ-lorraine.fr/hal-02735745}

Submitted on 2 Jun 2020

HAL is a multi-disciplinary open access archive for the deposit and dissemination of scientific research documents, whether they are published or not. The documents may come from teaching and research institutions in France or abroad, or from public or private research centers.
L'archive ouverte pluridisciplinaire HAL, est destinée au dépôt et à la diffusion de documents scientifiques de niveau recherche, publiés ou non, émanant des établissements d'enseignement et de recherche français ou étrangers, des laboratoires publics ou privés. 


2

\title{
A MULTI-SCALAR STUDY OF THE LONG-TERM REACTIVITY OF URANIUM MILL TAILINGS FROM BELLEZANE SITE (FRANCE)
}

\author{
M. BALLINI ${ }^{1}$, C. CHAUTARD ${ }^{1}$, J. NOS ${ }^{1}$, V. PHROMMAVANH ${ }^{1}$, C. BEAUCAIRE ${ }^{2}$, C. BESANCON ${ }^{1,3}$, A. \\ BOIZARD $^{4}$, M. CATHELINEAU ${ }^{4}$, C. PEIFFERT ${ }^{4}$, T. VERCOUTER ${ }^{5}$, E. VORS $^{5}$, M. DESCOSTES $^{1, *}$
}

${ }^{1}$ : ORANO Mining, R\&D Dpt, 125 avenue de Paris, F-92330 Châtillon, France

32 : DEN, Service d'Etude du Comportement des Radionucléides (SECR), CEA, Université Paris-Saclay, F-91191 4 Gif-sur-Yvette, France

$5{ }^{3}$ : Institut de Minéralogie de Physique des Matériaux et de Cosmochimie (IMPMC), Sorbonne Université, F-75005

6 Paris, France.

$7{ }^{4}$ : Université de Lorraine, CNRS, CREGU, GeoRessources, F-54000 Nancy, France

${ }^{5}$ : DEN, Service d'Etudes Analytiques et de Réactivité des Surfaces (SEARS), CEA, Université Paris-Saclay, F91191 Gif sur Yvette, France

\section{(1)}

(1)

3

* : corresponding author, michael.descostes@ orano.group 


\section{Abstract}

34 The mill tailings from uranium mines constitute very low-level, long-lived, radioactive process waste. Their long35 term management therefore requires a good understanding of the geochemical mechanisms regulating the mobility of residual $\mathrm{U}$ and ${ }^{226} \mathrm{Ra}$. This article presents the results of the detailed characterization of the tailings resulting from the dynamic leaching processes used on the ore of the La Crouzille mining division and stored at the Bellezane site (Haute-Vienne, France) for over 25 years. A multi-scalar and multidisciplinary approach was developed based on a study of the site's history, on the chemical, radiological and mineralogical characterizations of the solid fraction of the tailings, and on porewater analyses. These were supplemented by thermodynamic equilibrium models to predict the long-term mobility of $\mathrm{U}$ and ${ }^{226} \mathrm{Ra}$. Weakly acidic $(\mathrm{pH}=6.35)$ and oxidizing $(\mathrm{Eh}=138 \mathrm{mV} / \mathrm{SHE})$ porewaters had a sulfated-magnesian facies $\left(\left[\mathrm{SO}_{4}\right]_{\mathrm{tot}}=43 \mathrm{mmol} / \mathrm{L} ;[\mathrm{Mg}]_{\mathrm{tot}}=33 \mathrm{mmol} / \mathrm{L}\right)$ with an accessory calcium bicarbonate component $\left(\mathrm{TIC}=25 \mathrm{mmol} / \mathrm{L} ;[\mathrm{Ca}]_{\mathrm{tot}}=13 \mathrm{mmol} / \mathrm{L}\right)$ and dissolved concentrations of uranium and ${ }^{226} \mathrm{Ra}$ of $12 \times 10^{-}$ ${ }^{6} \mathrm{~mol} / \mathrm{L}$ and $0.58 \mathrm{~Bq} / \mathrm{L}$ respectively. Ultra-filtration at $10 \mathrm{kDa}$ indicated the absence of colloidal phases. The characterization of the tailings confirmed their homogeneity from a radiological, chemical and mineralogical point of view. The residual $\mathrm{U}$ and ${ }^{226} \mathrm{Ra}$ concentrations measured in the solid were $160 \mathrm{ppm}$ and $25 \mathrm{~Bq} / \mathrm{g}$ respectively, in accordance with the initial ore grades and mill yields, or more than $99 \%$ of the total stock. In terms of chemical and mineralogical composition, the tailings were mainly composed of minerals from the granitic ore (quartz, potassium feldspar, plagioclases and micas) in association with their weathering products (smectite and ferric oxyhydroxides) and with neo-formed minerals following rapid diagenesis after neutralization of the tailings before their emplacement (gypsum and barite). All these minerals are effective traps for the retention of $U$ and ${ }^{226} \mathrm{Ra}$. The uranium is distributed 52 partly in micrometer scale uraninite and coffinite refractory phases embedded in grains of quartz, and partly sorbed 53 to smectite and ferric oxyhydroxides. The ${ }^{226} \mathrm{Ra}$ on the other hand is trapped mainly within the barite. The aqueous concentrations of $\mathrm{U}$ and ${ }^{226} \mathrm{Ra}$ could be described using a thermodynamic approach so that their long-term mobility can subsequently be assessed by modeling. The paragenesis of the tailings could be seen to be stable over time with the exception of neo-formed gypsum and calcite, which will gradually dissolve. The presence of retention traps offering surplus capacity, i.e. smectite, ferric oxyhydroxides and barite, will maintain the $\mathrm{U}$ and the ${ }^{226} \mathrm{Ra}$ at very low aqueous concentrations, even under oxidizing conditions. Moreover, the low permeability of the mill tailings leads, in the case of ${ }^{226} \mathrm{Ra}$, to behavior dictated only by the radioactive decay. 
61 Highlights (no more than 85 characters, including spaces)

- U mill tailings from Bellezane (France) were studied 25y after their deposition (81 characters)

- $\mathrm{U}$ and ${ }^{226} \mathrm{Ra}$ are immobile through retention process (50 characters)

- U mobility is constrained by sorption onto smectite and ferrihydrite (70 characters)

- ${ }^{226} \mathrm{Ra}$ mobility is governed by coprecipitation into barite and radioactive decay ( 81 characters) 
67 Keywords (maximum of 6 keywords)

68 Uranium, mill tailings, ${ }^{226} \mathrm{Ra}$, geochemical modeling, reactivity, retention 69 
71 Graphical abstract

72

73 


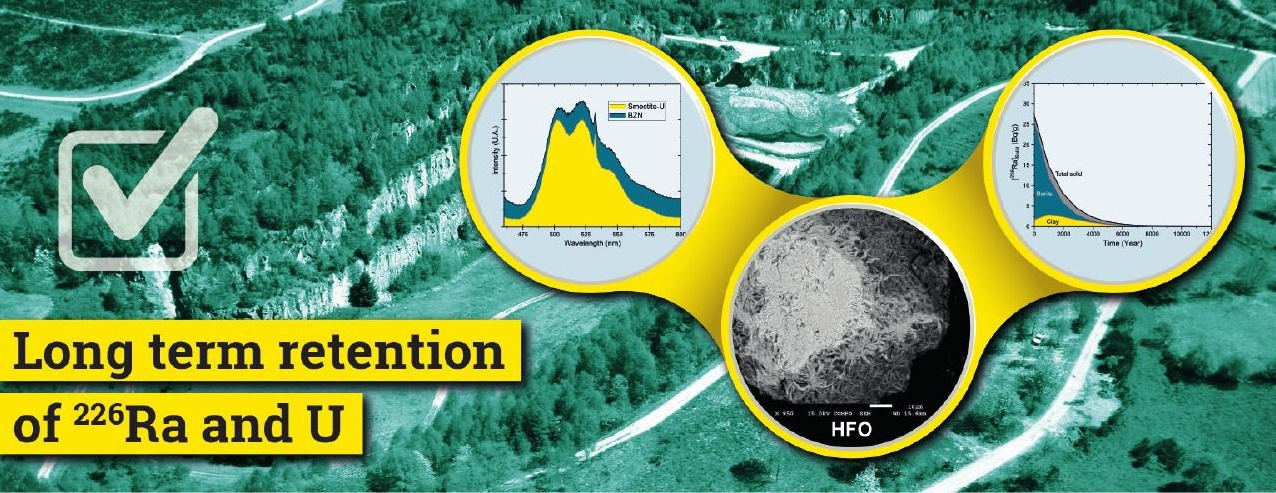


Uranium mining took place in France throughout the second half of the twentieth century (1948-2001) with some 250 mining sites of varying sizes being operated. This yielded aggregate production of $76,000 \mathrm{tU}$ at the national level, roughly the equivalent of a year's worldwide output today (WNA, 2019). At the same time, this activity generated nearly $160 \mathrm{Mt}$ of mine waste rock and $52 \mathrm{Mt}$ of mill tailings (AREVA, 2004).

During this period, the uranium mines were operated by conventional techniques, either as open-pit mines or underground mine workings. The ore was then milled either by heap leaching at the mining sites, or by dynamic leaching in eight processing plants or mills. The milling processes used were generally the same from case to case, consisting, after crushing the ore, in an acid extraction process in a sulfuric and oxidizing medium, involving a series of physico-chemical processes (mainly dissolution, oxidation, filtration, extraction, and concentration), leading to the formation of "yellowcake" on the one hand, and to the production of mill tailings on the other. The latter therefore corresponded to the fraction of the rock rejected after extracting most of the uranium through chemical processes. These mill tailings were then stored near the ore processing plants, as is the case for mines operating today overseas (see for instance Déjeant et al. (2016) for Niger and Robertson et al. (2019) for Canada).

Today, 17 storage facilities for mill tailings (referred to as Tailings Management Facilities or TMFs) are spread over 16 sites in France, generally located close to former production sites. Remediated in accordance with regulations on ICPE-classified environmentally regulated sites (ICPE - Installations Classées pour la Protection de l'Environnement), these TMFs are subject to environmental monitoring. Each TMF has a surface area of between one and a few dozen hectares. Depending on the mining method used, these sites may hold between a few thousand and several million tons of dynamic, static or combined process tailings (AREVA, 2004). This contrasts with current uranium extraction methods, as nearly $50 \%$ of the world's uranium production is now produced by In Situ Recovery, without production of mill tailings (WNA, 2019). The configuration chosen for these TMFs was determined according to the topography of each mining site. For example, the tailings could be stored "in-pit" by filling in the open pits of mined-out surface deposits, with or without a tailings dyke, or else in a thalweg dammed with a dyke. They are capped with a vegetated solid cover or water layer (see for example Chautard et al. (2017) for France and Robertson et al. (2019) for Canada). Finally, where tailings from dynamic leaching processes were cycloned, the coarser fraction was used to backfill old underground workings or to create dams, while the finer fraction was stored in tailings piles.

From a mineralogical and geochemical point of view, process tailings can be considered as milled ore that has undergone oxidative dissolution through a sulfuric medium and has a low residual uranium content. Chemical composition can sometimes be more complex because it depends on the nature of the ore undergoing the mill process, the mining process used, and the operating history of the TMF. The vast majority of the stored materials therefore consist of ore tailings, but may also contain a marginal proportion of slurry from water treatment stations. Indeed, there are three main elements of concern (or EOCs) - both from a chemical and radiological standpoint - generally associated with tailings: residual $\mathrm{U}$, radon $\left({ }^{222} \mathrm{Rn}\right)$ and radium $\left({ }^{226} \mathrm{Ra}\right)$. Despite the high extraction yields achieved by the mills, the residual $U$ is generally present in the tailings on average at concentrations in the order of 5 to $25 \%$ of that of the ore processed, i.e. in the order of $100 \mathrm{ppm}$, and may therefore present chemical toxicity in aqueous form. In addition, the mill tailings also contain the other non-extracted radionuclides belonging to the two families of natural 
uranium $\left({ }^{238} \mathrm{U}\right.$ and $\left.{ }^{235} \mathrm{U}\right)$ including radon $\left({ }^{222} \mathrm{Rn}\right)$ and radium $\left({ }^{226} \mathrm{Ra}\right)$. The installation of a solid cover or a water layer 113 limits the migration of radon in gaseous form. With its half-life $(\sim 1600$ years $)$ and high specific activity $\left(3.66 \times 10^{10}\right.$ $\left.114 \mathrm{~Bq} \cdot \mathrm{g}^{-1}\right)$, radium 226 is one of the main EOCs in the tailings solids. The tailings thus constitute very low-level, long115 lived, radioactive process waste.

116 Numerous studies have been conducted on the reactivity of U mill tailings (Fernandes et al., 1996; Abdelouas et al., 117 1998; Donahue et al., 2000; Martin et al., 2003; Moldovan et al., 2003; Landa, 2004; Scheinost et al., 2006; Essilfie118 Dughan et al., 2010; Déjeant et al., 2014; Yan and Luo, 2015; Chautard et al., 2017; Liu et al., 2017). However, these 119 studies are mostly specific to the sites considered and to the associated ores and processes. Indeed, apart from the uranium and radium, the reactivity of certain metals such as $\mathrm{Mo}, \mathrm{Ni}$, Se or As, which are sometimes present in 121 significant quantities in the ore and are still present in the tailings, mean that these are also EOCs, distinct from those 122 belonging to the ${ }^{238} \mathrm{U}$ radioactive decay chain.

123 Previous characterization work on ore tailings stored in France showed that they consist mainly of minerals inherited 124 from the original ore, as well as a smaller fraction of minerals (gypsum, clay minerals, metal hydroxides) that have 125 been neo-formed during rapid diagenesis after deposition (Somot et al., 1997, 2000; Nos et al., 2013; Ballini et al., 126 2017; Lestini et al., 2019). Consequently, mill tailings constitute a highly anthropized and complex reactive system 127 for investigation, wherein diagenesis and weathering phenomena are observed.

128 More generally, the mobility of uranium and radium in the environment has been the subject of considerable scientific 129 research (see Langmuir (1978) and Langmuir and Riese (1985)). Uranium has a complex chemistry mainly governed 130 in the natural environment by redox and $\mathrm{pH}$ conditions. Insoluble under reducing conditions, it has higher mobility 131 in an oxidizing environment, exacerbated under acid or alkaline conditions. Additionally, the presence of inorganic 132 (carbonate, sulfate, phosphate, silicate, etc.) or organic complexing agents can also increase the solubility of uranium 133 and hence its mobility in the environment. However, due to its concentration at trace level in the natural environment 134 (in the order of a few ppm), the mobility of uranium, even in hexavalent form, is strongly affected by sorption reactions at the surface of clay minerals (Catalano and Brown Jr, 2005; Schlegel and Descostes, 2009; Bachmaf and

Merkel, 2011; Tayal et al., 2019) or metal hydroxides (Ames et al., 1983a; Waite et al., 1994; Walter et al., 2003) frequently encountered in mining environments. Uranium can also in some cases be sorbed to organic matter (Cumberland et al., 2016; Bordelet et al., 2018), or else form very poorly soluble phosphate minerals (Murakami et al., 1997; Cretaz et al., 2013). Due to its very low elemental concentration $\left(1 \mathrm{~Bq} / \mathrm{L} \sim 1.21 \times 10^{-13} \mathrm{~mol} / \mathrm{L} \sim 27.3 \mathrm{pg} / \mathrm{L}\right)$, ${ }^{226} \mathrm{Ra}$ is regarded as an ultra-trace element with a fairly simple aqueous speciation (Molinari and Snodgrass, 1990). The geochemistry of ${ }^{226} \mathrm{Ra}$ in the natural environment is exclusively governed by interface reactions such as sorption on clay minerals (Ames et al., 1983b; Tachi et al., 2001; Reinoso-Maset and Ly, 2016; Robin et al., 2017), metal oxides and oxyhydroxides (Ames et al., 1983b; Nirdosh et al., 1984; Sajih et al., 2014), carbonates (Jones et al., 2011), organic matter (Bordelet et al. (2018) and references included), but also co-precipitation within sulfate-bearing minerals (Zhu, 2004; Curti et al., 2010; Zhang et al., 2014; Brandt et al., 2015; Lestini et al., 2019) such as gypsum $\left(\mathrm{CaSO}_{4} \cdot 2 \mathrm{H}_{2} \mathrm{O}\right)$, celestine $\left(\mathrm{SrSO}_{4}\right)$ and barite $\left(\mathrm{BaSO}_{4}\right)$. Unfortunately, it is still difficult to directly access the location of ${ }^{226} \mathrm{Ra}$ at the mineral scale, although recent work focusing on alpha autoradiography points to some promising possibilities with observations at the micrometer scale (Sardini et al., 2016; Angileri et al., 2018). Often the only approach put forward for identifying the ${ }^{226} \mathrm{Ra}$ carrier phases is the use of sequential leaching, a method which frequently leads to interpretation bias (Bacon and Davidson, 2008). 
This article presents the results of the long-term reactivity study on dynamic process tailings resulting from the milling of ore at the La Crouzille mining division and stored at the Bellezane site (Haute-Vienne, France). To conduct this study, a multi-scalar and multidisciplinary approach had been devised. This had been based on an investigation of the site's history, allowing an understanding of the composition of the tailings storage on a macroscopic scale, on chemical, radiological and mineralogical characterizations of the solid fraction of the $\mathrm{U}$ mill tailings, and on porewater analyses. These data were complemented by thermodynamic equilibrium modeling to better understand the water-rock interactions, which in a second step allowed the long-term mobility of $U$ and ${ }^{226} \mathrm{Ra}$ to be assessed through the development of a 1D predictive model of reactive transport. This study therefore presents unique findings in relation to the characterization and understanding of the long-term geochemical evolution of $U$ mill tailings some 25 years after their emplacement. The findings were based on multi-year studies (Descostes et al., 2013; Nos et al., 2014; Ballini, 2017) carried out under the French National Radioactive Materials and Waste Management Plan (PNGMDR ; (ASN, 2019)).

\section{La Crouzille Mining Division and the Bellezane site}

The mining division of La Crouzille is located in Haute Vienne (France), within a $20 \mathrm{~km}$ radius of the town of (Bavoux and Guiollard, 2003), characterized by large granitic intrusions, particularly rich in uranium, and that were formed between 360 and 290 m.y. ago during the Hercynian orogenesis. From west to east, the mining division comprises the Brâme massif, the St-Sylvestre massif and the Marche (or Guéret) massif (Scaillet et al., 1996).

Most of the deposits developed within the La Crouzille mining division are concentrated in the St-Sylvestre massif and more precisely in the two-mica (biotite and muscovite) St-Sylvestre leucogranite (formed $318 \pm 15$ m.y. ago). Its chemical composition is shown below in Figure 1. In this massif, veins of lamprophyres (vein-type microgranular magmatic rock) with biotite, pyroxenes and peridots, microgranite veins, with biotite and plagioclase phenocrysts, and episyenites (de-quartzified granites), sometimes highly mineralized, present as columns or clusters, are also observed (Scaillet et al. (1996) and Kanzari et al. (2017) and references included).

Mineralization consists of silicates or uranium oxides (coffinite and uraninite) at depth and accompanied by surficial weathering minerals such as phosphates or hydrated uranium oxides (autunite and gummite) (Barbier and Ranchin, 1969). The mean uranium content of the ores in the La Crouzille division ranged from $0.49 \%$ in the DaumartMargnac sector and 7\%o for the Henriette mine (Figure SI-1) (Paucard, 2007).

The Crouzille mining division was the principal uranium production area in France with about twenty separate mining operations, representing a production of $27,000 \mathrm{tU}$ in the form of ammonium diuranate (ADU) containing $75 \%$ uranium, for nearly $15 \mathrm{Mt}$ of ore processed. This mining activity generated in addition nearly $57 \mathrm{Mt}$ of mine waste rock and $22 \mathrm{Mt}$ of process tailings (AREVA, 2004; Kanzari et al., 2017).

Between 1958 and 1993, the ore from the La Crouzille mining division (average grade $1.66 \%$ ) was processed by the SIMO mill (Société Industrielle des Minerais de l'Ouest, 95\% yield (Bavoux and Guiollard, 2003)) at Bessinessur-Gartempe by an acid extraction process, which was either heap leaching (8,614,000 tons of ore) or dynamic leaching $(14,839,000$ tons of ore) depending on the ore grade (Bavoux and Guiollard, 2003). In the case of dynamic leaching, the ore was crushed and then ground to a pulp with a granulometry of under $450 \mu \mathrm{m}$ (Bavoux and Guiollard, 
2003). The pulp was then treated by adding sulfuric acid at $65^{\circ} \mathrm{C}$ in the presence of sodium chlorate as an oxidizing agent. After filtration, the solid waste was washed, neutralized with lime $(\mathrm{CaO})$ and transferred to a storage pond. The processes changed very little during the entire operation of the mill.

The process tailings produced by the SIMO mill were stored at the Bessines industrial site (Lavaugrasse) from 1958 to 1978 and in the former open-pit mine of Brugeaud until 1987. Subsequently, two tailings management facilities (TMFs) were created with the erection of peripheral dams at the Montmassacrot site (between 1987 and 1990) and at the Bellezane site (BZN) (between 1989 and 1993) (Figure SI-1). In total, 1,546,000t of mill tailings are stored at the BZN site, $97 \%$ of which are the product of dynamic leaching and take the form of fine clayey sand with a particle size of under $450 \mu \mathrm{m}$.

Before becoming a tailings disposal site, the BZN site was an active mining site between 1975 and 1992 with seven open-pit mines of various sizes as well as underground workings. The open-pit workings were partially backfilled as mining progressed with both waste rock and mill tailings. In the case of pit MCO 68, this was from February 1989 to July 1990, and then for pit MCO 105 from August 1990 to July 1993 (Figure 1). The final remediation of the site took place in 1996, when the process tailings in MCO 105 and MCO 68 were covered over with a layer of waste rock both for mechanical protection (against erosion, intrusion) and for radiological protection (to limit radiation emissions and radon migration). The storage facility, as well as the remodeled areas of the entire site, were covered over in 1998 with a layer of topsoil and then revegetated (Figure 2). Today, the BZN site, consisting of a TMF and waste rock disposal site, is subject to environmental monitoring. Drainage water is discharged, after treatment, into a stream (Les petites Magnelles), a tributary of the river Gartempe.

From a hydrogeological point of view, previous work in this area showed that the process tailings are saturated and that their permeability is very low, in the range of $10^{-9}$ to $10^{-8} \mathrm{~m} \cdot \mathrm{s}^{-1}$ (Ledoux and Schmitt, 2010). This was confirmed notably by the strong correlation between atmospheric pressure and the piezometric level of the piezometer implanted in the tailings (Figure SI-2), such a correlation being typical of media with very low permeability (Fatmi et al., 2008). Water movements are therefore very limited within the TMF.

The mill tailings stored in the two open-pit mines at the BZN site were described as homogeneous in terms of particle size $(<450 \mu \mathrm{m})$, mineralogy and chemistry (Somot et al., 1997, 2000). In fact, the ores from the two mining operations, processed at the SIMO mill, had very similar chemical and mineralogical compositions, while the mill processes were not significantly modified between 1989 and 1993, during which period the tailings were stored at the BZN site.

\section{Methods and materials}

\subsection{Core drilling and sampling strategy for solids}

A sonic percussion borehole was drilled in April 2011 in the downstream part of the MCO 105 pit for the BZN 1 survey. Tailings samples were collected over the entire height of the storage, with a recovery rate of $\sim 80 \%$. The sampling was carried out in $1.5 \mathrm{~m}$ long runs on average, which were dry-subdivided into sections of 30 to $50 \mathrm{~cm}$ in length. Drilling, cutting and sampling techniques were chosen to avoid water inflows and preserve the sediment structure. 
The samples are composed of brown and ochre fine-grain tailings, with locally darker brown and black layers and a high degree of homogeneity of facies. Dose rate measurements using a CANBERRA INSPECTOR 1000 ( $\mathrm{LaBr}$ ) radiometric probe approximately every $25 \mathrm{~cm}$ showed slight variability with depth, with values ranging from 0.4 to $0.7 \mu \mathrm{Sv} / \mathrm{h}$ for the first samples taken from 0 to $7.5 \mathrm{~m}$ deep (mine waste rock used as solid cover) and higher values ranging from 1.3 to $4.1 \mu \mathrm{Sv} / \mathrm{h}$ for at higher depth (process tailings in the strict sense). After observing the facies and analyzing the dose rate of each section, thirteen of core samples were selected at regular two-meter intervals to be representative of the entire height of the tailings storage (Figure 3). Two sections exhibiting a radiometric peak and one section corresponding to a radiometric drop were also selected. Each section was divided longitudinally into two equal parts for dose rate measurement and lithological observations. A total of 16 sections were sampled for chemical analysis, and for mineralogical and radiological characterization (Figure SI-3 and Table SI-1).

\subsection{Analysis of the solid samples}

Samples were characterized using different complementary analytical techniques. Considering the chemical, mineralogical and granulometric homogeneity of the samples, these characterizations were performed in some cases on a reduced number of samples.

\subsubsection{Particle size distribution}

Only one specimen (BZN_1_13.25-14.75m_2T) was used for particle size characterization. This sample was selected on account of its relatively high $\mathrm{U}$ content $(240 \mathrm{ppm})$ and is deemed to be representative of all the samples taken. The characterizations were performed by dry sieving on a total mass of $630 \mathrm{~g}$, to avoid the dissolution of soluble minerals such as gypsum and to avoid altering the chemical composition distribution within each grading category. The sieving thresholds applied were: $2 \mathrm{~mm}, 400 \mu \mathrm{m}, 250 \mu \mathrm{m}, 100 \mu \mathrm{m}$ and $40 \mu \mathrm{m}$. Once separated, the different grading families were weighed and then subjected to chemical and radiological analyses.

\subsubsection{Elemental and radiological compositions}

The samples were previously ground in an agate bowl. After being fused with $\mathrm{LiBO}_{2}$ and dissolved in acid solution. Major and trace elements concentrations were determined by ICP-OES (Thermo Elemental IRIS radial) and ICP-MS (Perkin-Elmer Elan 6000), respectively. Loss of ignition (LOI) measurements were complementary performed. Analytical uncertainties range from 1 to $15 \%$ for ICP-OES and from 5 to $15 \%$ for ICP-MS. Total $\mathrm{CO}_{2}$ (uncertainty $<5 \%$ ), $\mathrm{C}_{\text {org }}$ (uncertainty $<20 \%$ ) and S (uncertainty $<2 \%$ ) concentrations were determined with a Leco SC 144DR apparatus by calcining the sample under oxygen stream at $1400^{\circ} \mathrm{C}$ in the presence or not of an oxidant (iron phosphate). For $\mathrm{C}_{\mathrm{org}}$, the measurement was carried out after elimination of the carbonates with $\mathrm{HCl}$. The total inorganic carbon (TIC) content was calculated from the difference between the total $\mathrm{CO}_{2}$ and $\mathrm{C}_{\text {org }}$ concentrations.

The ${ }^{238} \mathrm{U},{ }^{234} \mathrm{Th}$ and ${ }^{226} \mathrm{Ra}$ concentrations were also determined on the previously ground samples, after a one-month waiting period so that daughters ${ }^{214} \mathrm{~Pb}$ and ${ }^{214} \mathrm{Bi}$ would be in equilibrium with their parent. The measurements were made by gamma-ray spectrometry according to the NF ISO 18589-3 standard (apparatus comprising Canberra COAX type N type EGC 35-195-R, Canberra BEGe type BE5030P and DSG type NGC 4021). 


\subsubsection{Mineralogy}

264 As the BZN samples were already relatively fine, no grinding was necessary prior to characterization by X-ray diffraction. The characterizations were performed in parallel with a Bruker D8 diffractometer (CREGU, Nancy) and an X'Pert Pro Panalytical (IMPMC-UPMC, Paris), both with Cobalt anode. Two types of samples were analyzed: on the one hand, non-oriented bulk rock powders used to determine the predominantly present mineral phases and, on the other hand, fractions $<2 \mu \mathrm{m}$ collected by wet granulometric separation on bulk samples, in the form of oriented deposits to more accurately determine the presence of clay minerals. These oriented preparations were then treated with ethylene glycol and heated to $550^{\circ} \mathrm{C}$ for 3 hours.

Seven tailings samples were studied using a scanning electron microscope (SEM) on a thin section and/or in powder form. The observations were made on a Hitachi FEG S4800 device coupled with a wavelength dispersion spectrometer (WDS). For thin sections, a JEOL JSM7600F scanning electron microscope was also used.

Uranium (VI) carrier phases were identified directly on samples fixed in resin used to make the thin sections using time-resolved laser-induced fluorescence spectrometry (TRLFS) (Vercouter et al., 2017). A sorbed U-doped montmorillonite was used as U(VI) reference compound already studied by Tayal et al. (2019). Measurements were made using an arrangement featuring a $266 \mathrm{~nm}$ nanosecond excitation laser and collection of luminescence emission through an optical fiber connected to a monochromator and an intensified CCD camera (Othmane et al., 2016).

\subsection{Porewater chemistry}

The porewater from the process tailings was sampled in July 2013 in piezometer ES85 capturing the core of the storage located near the BZN 1 borehole using a WATERRA pump. A complete purge of the piezometer was performed the day before the sampling. A second (partial) purge was carried out just before sampling, until the physico-chemical parameters were stabilized. The physico-chemical parameters were measured online using a HORIBA probe (model W-22XD) for $\mathrm{pH}$, redox potential and temperature, a WTW TetraCon 325 electrode for conductivity and a WTW FDO 925 electrode for dissolved oxygen. All the probes were pre-calibrated.

On site, immediately after sampling, the samples were filtered through a $0.2 \mu \mathrm{m}$ pore-size filter. The samples were also immediately ultrafiltered through $10 \mathrm{kDa}$ using BIOMAX membranes for analysis of anions, organic carbon $\left(\mathrm{C}_{\mathrm{Org}}\right)$, major cations, metals, $\mathrm{U}$ and ${ }^{226} \mathrm{Ra}$ to verify the presence of colloids. All samples were acidified for conservation $\left(\mathrm{HNO}_{3} \mathrm{pH} 2\right)$ except for the anion and $\mathrm{C}_{\mathrm{Org}}$ fractions. The alkalinity was also measured by titration with sulfuric acid immediately after field filtration allowing the total inorganic carbon concentration (TIC) to be recalculated. The samples were then analyzed for anions by ion chromatography (DIONEX ICS 5000 - DX 500, standard NF EN ISO 10304-1), the sulfate and phosphate ions being determined by photometry (Thermofisher AQUAKEM 250 sequential analyzer, NF T 90-040 and NF EN ISO 6878 standards). The concentrations of the major cations ( $\mathrm{Na}, \mathrm{K}, \mathrm{Ca}, \mathrm{Mg}$ ) were determined by flame atomic absorption (AGILENT AA240, standards NF T90-020 and NF EN 7980). Si and trace elements (Al, As, Ba, Cu, Fe, Mn, Mo, Sc, Se, Sr, V) were assayed by ICP-AES (VARIAN 720ES, standards NF EN ISO 11885 and 2 N) but also by ICP-MS (THERMO ELECTRON X7, standard ISO 17294-2) for rare earth elements (Ce, Dy, Er, Eu, Gd, Ho, La, Lu, Nd, Pr, Sm, Tb, Tm, Y, Y, Yb) and U. Dissolved total organic carbon was quantified on a Shimadzu TOC VCPN analyzer (standard 79 N). Lastly, aqueous 
${ }^{226} \mathrm{Ra}$ activities were determined by gamma-ray spectrometry after a one-month waiting period (see Section 3.2.2 Elemental and radiological compositions).

\subsection{Reactive transport modeling}

304 Modeling was carried out using PhreeqC software (Parkurst and Appelo, 1999) to describe the speciation and 305 distribution of $\mathrm{U}$ and ${ }^{226} \mathrm{Ra}$ in the porewater and tailings system in thermodynamic equilibrium, and to evaluate $\mathrm{U}$ 306 and ${ }^{226} \mathrm{Ra}$ concentrations over the mid-term and long-term using predictive calculations according to a 1D model for 307 reactive transport.

308 The thermodynamic database used for the construction of the geochemical models was the LLNL database (llnl.dat 3094023 2010-02-09) for PhreeqC. The ionic strength correction model used was the extended Debye-Huckel model, 310 considered sufficiently accurate to predict the activities of aqueous species up to ionic forces of 0.3 to 1 molal 311 (Bethke, 2007). Sorption of major elements and Ba onto ferrihydrite (HFO) was taken into account via the surface 312 complexation model of Dzombak and Morel (1990) and the constants already incorporated in the LLNL database. 313 Sorption of $\mathrm{U}$ and ${ }^{226} \mathrm{Ra}$ and carbonates onto ferrihydrite was implemented in the database considering surface 314 complexation data from Mahoney et al. (2009) and Sajih et al. (2014). Cation exchange reactions on montmorillonite of the major cations, uranium and radium 226 were incorporated considering a multi-site ion exchange model (Reinoso-Maset et al., 2012a, 2012b; Reinoso-Maset and Ly, 2014, 2016). The sorption constants used are indicated in Tables SI-2 and SI-3. The incorporation of ${ }^{226} \mathrm{Ra}$ into a solid solution (Ba,Ra)SO${ }_{4}$ was considered using the concentrations of ${ }^{226} \mathrm{Ra}, \mathrm{Ba}$ and $\mathrm{SO}_{4}{ }^{2-}$ measured in the tailings porewater and the total contents of $\mathrm{Ba}$ and $\mathrm{Ra}$ in the tailings. The solid/solution distribution coefficient (D) for Ra, under thermodynamic equilibrium conditions is expressed as follows:

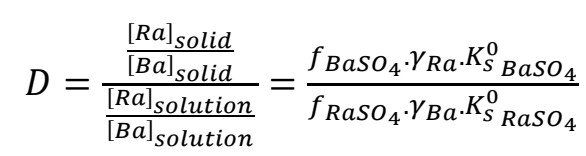

$K_{\mathrm{SaSO}_{4}}^{0}$ and $K_{\mathrm{SaSO}_{4}}^{0}$ are the respective solubility constants of $\mathrm{BaSO}_{4}$ and $\mathrm{RaSO}_{4}, \gamma$ and $f$ respectively representing

the activity coefficients of $\mathrm{Ba}, \mathrm{Ra}$ in the aqueous solution and in the solid solution. Assuming a regular, diluted solid solution, the activity coefficients in the solid solution are defined as follows: $\operatorname{Ln} f_{\mathrm{BaSO} 4}=0$ and $\operatorname{Ln} f_{\mathrm{RaSO} 4}=\mathrm{a}_{0}, \mathrm{a}_{0}$ being a parameter reflecting the deviation from ideality (Curti et al., 2010). A solid-solution model was therefore implemented, with a Guggenheim mean parameter $\mathrm{a}_{0}$ of 1.27 in agreement with values reported in Brandt et al. (2015) and Vinograd et al. (2013) (e.g. $\mathrm{a}_{0}=1.0 \pm 0.4$ ). The molar fraction in the solid solution was calculated and led to a molar fraction of ${ }^{226} \mathrm{Ra}$ in the solid solution of $4.6 \times 10^{-7}$. This results in a distribution coefficient of 0.21 in agreement with values already reported in Lestini et al. (2019).

The geometry of the 1D transport model amounted to a column of 25 cells $1 \mathrm{~m}$ high, representing a vertical section (height $25 \mathrm{~m}$ ) of the process tailings in the open-pit mine MCO 105 under saturated conditions. The initial conditions of the water-tailings system are described in Section 5.1 and correspond to the steady state of the pore solutions with the mineral paragenesis observed in the tailings. The transport parameters were taken from Ledoux et Schmitt (2010), namely a porosity of 0.33 , a permeability of $5 \times 10^{-8} \mathrm{~m} \cdot \mathrm{s}^{-1}$ (high assumption) and a hydraulic load gradient of 0.16 , which means a low flow velocity in the tailings of $8 \times 10^{-8} \mathrm{~m}^{-1}$. It therefore requires 99 years to pass through the 25 $m$ of tailings. In this simplified configuration, the phenomena of dispersion and molecular diffusion had been 
disregarded, only the advective transport of the solutions being taken into account. Water percolates from the top to the bottom of the column. The composition of the percolating solution (Table 1) is based on analyses of samples taken in 2008 from the superficial granitic aquifer (ES60; Ledoux and Schmitt (2010)). The water is weakly mineralized, containing sodium bicarbonate, of low ionic strength $\left(\mathrm{I}=1.6910^{-3} \mathrm{~mol} / \mathrm{L}\right)$, slightly acidic $(\mathrm{pH}=6.31)$ and oxidizing ( $\mathrm{Eh}=319 \mathrm{mV} / \mathrm{SHE}$ ). It is close to the solubility equilibrium for some aluminosilicates, including smectites, feldspars and muscovite, quartz polymorphs, aluminum hydroxides, ferrihydrite, and barite and therefore with the initial mineral assemblage used in the model (see Section 5.1 Current distribution of $\mathrm{U}$ and ${ }^{226} \mathrm{Ra}$ ). Lastly, it is under-saturated with respect to all uranium-carrying phases with a uranium concentration $\left(1.7 \times 10^{-8} \mathrm{~mol} / \mathrm{L}\right)$ three orders of magnitude lower than that of the tailings porewater $\left(1.19 \times 10^{-5} \mathrm{~mol} / \mathrm{L}\right)$. In addition, the ${ }^{226} \mathrm{Ra}$ specific activity is $0.2 \mathrm{~Bq} / \mathrm{L}$, which represents one third of the specific activity measured in the tailings.

The modeling was carried out over a total period of 230,000 years in order to better assess the long-term reactivity of the tailings and in particular the processes at the interfaces regulating the aqueous concentrations of $\mathrm{U}$ and ${ }^{226} \mathrm{Ra}$. This time span is naturally longer than 16,000 years, i.e. 10 times the radioactive half-life of ${ }^{226} \mathrm{Ra}$. A correction for the radioactive decay of ${ }^{226} \mathrm{Ra}$ was performed retrospectively. Finally, production of ${ }^{226} \mathrm{Ra}$ from the residual stock of $\mathrm{U}$ in the tailings was not considered.

\section{Geochemical and mineralogical characterization of the mill tailings}

\subsection{Composition of the porewaters}

The waters taken from the core of the tailings were weakly acidic $(\mathrm{pH}=6.35)$, weakly oxidizing $(\mathrm{Eh}=138 \mathrm{mV} / \mathrm{SHE})$ and exhibited high ionic strength $(0.13 \mathrm{~mol} / \mathrm{L}$; electrical conductivity $=7630 \mathrm{mS} / \mathrm{cm})$. The analyses displayed a satisfactory ionic balance of 6.2 and 5.8\% respectively for the fraction filtered at $0.2 \mu \mathrm{m}$ and $10 \mathrm{kDa}$, allowing these results to be exploited (Table 1). These waters had a sulfated-magnesian facies $\left(\left[\mathrm{SO}_{4}\right]_{\text {tot }}=43 \mathrm{mmol} / \mathrm{L}\right.$; $\left.[\mathrm{Mg}]_{\mathrm{tot}}=33 \mathrm{mmol} / \mathrm{L}\right)$ with a calcium bicarbonate component $\left(\mathrm{TIC}=25 \mathrm{mmol} / \mathrm{L} ;[\mathrm{Ca}]_{\mathrm{tot}}=13 \mathrm{mmol} / \mathrm{L}\right)$ ). In addition to chloride ions $(8.5 \mathrm{mmol} / \mathrm{L})$ and sodium ions $(8.9 \mathrm{mmol} / \mathrm{L})$, iron and manganese were also observed at significant concentrations $\left(7.9 \mathrm{mmol} / \mathrm{L}\right.$ and $1 \mathrm{mmol} / \mathrm{L}$ respectively). The concentrations of uranium and ${ }^{226} \mathrm{Ra}$ were $12 \times 10^{-6} \mathrm{~mol} / \mathrm{L}$ and $7 \times 10^{-14} \mathrm{~mol} / \mathrm{L}(0.58 \mathrm{~Bq} / \mathrm{L})$ respectively.

Figure SI-4 shows the concentration ratio of both $0.2 \mu \mathrm{m}$ and $10 \mathrm{kDa}$ fraction for each EOC. Concentration ratios close to 1 (taking into account the measurement uncertainty) indicate an absence of colloidal phases in the sample. Examination of the ratios between the two fractions also shows that uranium and ${ }^{226} \mathrm{Ra}$ are mainly present in dissolved form. In the case of ${ }^{226} \mathrm{Ra}$, the large variation in the ratio is due to the uncertainty of the measurement of this element (40\%), which nevertheless remains at low concentration. However, exceptions are observed for nitrates $\left(\sim 10^{-6}-10^{-5}\right.$ $\mathrm{mol} / \mathrm{L})$ and copper $\left(\sim 10^{-9}-10^{-8} \mathrm{~mol} / \mathrm{L}\right)$ due to the cleaning protocol of the ultrafiltration device (successive rinses with $\mathrm{HNO}_{3}$, distilled water, basic solution to remove organic matter, distilled water) and to the pollution from the ultrafiltration system, respectively. Nonetheless, both elements concentration in each fraction remain at trace level. 


\subsection{Mill tailings}

\section{2}

373

374

375

376

377

378

379

380

381

382

383

384

385

386

387

388

389

390

391

392

393

394

395

396

397

398

399

400

401

402

403

\subsubsection{Chemical composition}

The chemical composition of the mill tailings was very homogeneous over all the samples taken as shown in Figure 4. The samples were mainly composed of $\mathrm{Si}, \mathrm{Al}, \mathrm{K}, \mathrm{Ca}, \mathrm{Fe}, \mathrm{S}, \mathrm{Na}$ and $\mathrm{Mg}$ in accordance with the initial composition of the ore. The average element contents measured are given in Table SI-4, as well as the minimum and maximum levels. Levels of $\mathrm{P}, \mathrm{Ti}$ and $\mathrm{Mn}$ were an order of magnitude lower (less than $1 \%$, by weight of oxide). The total $\mathrm{CO}_{2}$ contents were also fairly low in the order of $0.5 \%$. C Org $_{\text {rg }}$ contents were also quite low $(0.28 \%)$, reflecting TIC (Total Inorganic Carbon) contents in the order of $0.22 \%$. Concentrations of trace elements are available in Supplementary Information (Table SI-4).

The average concentrations measured are quite close to those measured within the mineralized or non-mineralized granites of the Saint-Sylvestre Massif, as shown in Figure 1. The only differences are in the measured concentrations of $\mathrm{S}, \mathrm{Ca}$, TIC and LOI, which are much lower in the reference and mineralized granites than in the tailings (CaO: 0.9$0.5 \%$ vs. $3.4-3.3 \%$; S: $0.0015-0.05 \%$ vs. $1.8-1.5 \%$; TIC : $\sim 0.03-0.1 \%$ vs. $0.22-0.6 \%$; LOI : 0.7-3.3\% vs. 9.5$8.2 \%)$.

$\mathrm{Ca}$ and $\mathrm{S}$ concentrations are consistent with the presence of gypsum $\left(\mathrm{CaSO}_{4} \cdot 2 \mathrm{H}_{2} \mathrm{O}\right)$ and to a lesser extent of calcite, in agreement with the mineralogical characterizations presented below. This is illustrated in Figure 5a, where $\mathrm{S}$ and TIC concentrations are indicated as a function of Ca content (expressed in mol/100g). A good correlation is observed between $\mathrm{S}$ and $\mathrm{Ca}$ contents, with a $\mathrm{S} / \mathrm{Ca}$ molar ratio slightly below 1, i.e. slightly below the $\mathrm{S} / \mathrm{Ca}$ molar ratio in gypsum $\left(\mathrm{CaSO}_{4} \cdot 2 \mathrm{H}_{2} \mathrm{O}\right)$. On the other hand, the molar ratio ( $\left.\mathrm{S}+\mathrm{TIC}\right) / \mathrm{Ca}$ is very close to 1 , this excess of $\mathrm{Ca}$ being interpreted by the distribution of $\mathrm{Ca}$ within other phases such as carbonated minerals (calcite). Additionally, the good correlation LOI/S evidenced the presence of gypsum (see Figure 5b). Indeed, this mineral is strongly hydrated and can therefore be first approximated using the simple parameter of LOI. Sulfur is also present as sulfides, but in much smaller proportions (see Section 4.2.4 Mineralogical characterization).

These enrichments in Ca, S and TIC are due to the initial presence of a neutralizing limewash slurry in the process tailings. The additional calcium reacts with the residual sulfur from the sulfuric acid leach to form gypsum (hydrated mineral) which is consistent with the high $\mathrm{Ca}, \mathrm{S}$ and LOI levels and mineralogical observations. The addition of lime has also resulted, by increasing the $\mathrm{pH}$, in the formation of carbonate precipitates in the slurries, by reacting with $\mathrm{CO}_{2}$ from the air, a source of carbon.

All the results of the chemical and radiological characterizations are presented in the form of an element correlation matrix in Supplementary Information (Table SI-5). The correlation coefficients calculated confirm the presence of two fractions: the first enriched in $\mathrm{Si}$ and $\mathrm{Na}\left(\mathrm{R}_{\mathrm{SiO2}-\mathrm{Na} 2 \mathrm{O}}=0.74\right)$ corresponding to the residual ore, and a second enriched in $\mathrm{Ca}\left(\mathrm{R}_{\mathrm{SiO2}-\mathrm{CaO}}=-0.92\right), \mathrm{Mg}\left(\mathrm{R}_{\mathrm{SiO} 2-\mathrm{MgO}}=-0.83\right), \mathrm{Fe}\left(\mathrm{R}_{\mathrm{SiO} 2-\mathrm{Fe} 2 \mathrm{O} 3}=-0.93\right), \mathrm{S}\left(\mathrm{R}_{\mathrm{SiO}-\mathrm{S}}=-0,90\right)$ and water content $\left(\mathrm{R}_{\mathrm{SiO} 2-\mathrm{H} 2 \mathrm{O}}=-0.92\right)$ and LOI $\left(\mathrm{R}_{\mathrm{SiO} 2-\mathrm{LOI}}=-0.94\right)$ which is interpreted as tracing the presence of neo-formed minerals including gypsum $\left(\mathrm{R}_{\mathrm{S}-\mathrm{CaO}}=0.94, \mathrm{R}_{\mathrm{S}-\mathrm{H} 2 \mathrm{O}}=0.87, \mathrm{R}_{\mathrm{S}-\mathrm{LOI}}=0.92\right)$.

The other main correlations highlighted concern REE-type trace elements with $\mathrm{Zr}$, Ti and $\mathrm{P}_{2} \mathrm{O}_{5}$ consistent with the presence of accessory heavy minerals such as zircon, titanium oxide and monazite (see Section 4.2.4 Mineralogical characterization). 
The U and ${ }^{226} \mathrm{Ra}$ concentrations measured were relatively constant for all the mill tailings samples (see Table SI-4) with mean values of $169 \pm 61 \mathrm{ppm}$ and $23 \pm 15 \mathrm{~Bq} / \mathrm{g}$ respectively. The significantly higher concentrations of U (292.4 and $239.3 \mathrm{ppm}$ ) were found at the highest dose rate values (at a depth of 9 and $14 \mathrm{~m}$; see Figure 3). The measured values are consistent with the yields (90-95\%) and average U content of the ore milled at the SIMO plant (1.66\%o). Furthermore, the ${ }^{226} \mathrm{Ra}$ activities measured are also of the same order of magnitude as those expected for an ore with an average grade of $1.66 \%$ at secular equilibrium before processing in the mill $(20.7 \mathrm{~Bq} / \mathrm{g})$. An examination of the profiles of the $\left[{ }^{238} \mathrm{U}\right] /\left[{ }^{226} \mathrm{Ra}\right]$ activity ratio, calculated from the ${ }^{234} \mathrm{Th}$ activity measurements (assimilated to ${ }^{238} \mathrm{U}$ activity), can be interpreted in terms of $U$ extraction efficiency, but may also illustrate the presence of unprocessed ores and/or differential migration of the $\mathrm{U}$ and ${ }^{226} \mathrm{Ra}$ (Figure 4). As the $\mathrm{U}$ was extracted during mining operations, the observed $\left[{ }^{238} \mathrm{U}\right] /\left[{ }^{226} \mathrm{Ra}\right]$ ratio is logically low. The two most superficial samples (at depths of about 1 and $4 \mathrm{~m}$ ) were close to radioactive equilibrium $\left(\left[{ }^{238} \mathrm{U}\right] / 226 \mathrm{Ra}\right] \sim 1$ with $\mathrm{U}$ concentrations less than or equal to $\left.30 \mathrm{ppm}\right)$. Then, below $7 \mathrm{~m}$ in depth, the activity ratio was low and fluctuated little, ranging from 0.04 to 0.08 . The cover over the tailings repository consists of mine waste rock whose $\left[{ }^{238} \mathrm{U}\right] /\left[{ }^{226} \mathrm{Ra}\right]$ activity ratio is close to equilibrium, and therefore higher than that of the process tailings. The low and homogeneous $\left[{ }^{238} U\right] /\left[{ }^{226} \mathrm{Ra}\right]$ values observed in the tailings confirm respectively that the extraction of $U$ during the mill process was effective and that in principle there was no differential migration of $\mathrm{U}$ and ${ }^{226} \mathrm{Ra}$.

The element correlation matrix (Table SI-6) also provides some insight into the distribution of ${ }^{226} \mathrm{Ra}$ and U. Indeed, ${ }^{226} \mathrm{Ra}$ concentrations were positively correlated with those of $\mathrm{U}\left(\mathrm{R}_{226 \mathrm{Ra}-\mathrm{U}}=0.80\right)$, which is consistent with a fraction of ${ }^{226} \mathrm{Ra}$ associated with refractory uranium minerals (see Section 4.2.4 Mineralogical characterization). However, the difference in concentrations between ${ }^{226} \mathrm{Ra}$ and the other chemical elements analyzed does not allow for clear identification of reliable elemental correlations. Thus, considering Ba and $\mathrm{Fe}$, which are in principle the chemical elements tracing the carrier phases at the origin of ${ }^{226}$ Ra retention (barite, ferric oxyhydroxides), no correlation was found $\left(\mathrm{R}_{226 \mathrm{Ra}-\mathrm{Ba}}=0.11\right.$ and $\left.\mathrm{R}_{226 \mathrm{Ra}-\mathrm{Fe} 2 \mathrm{O} 3}=0.51\right)$, except with $\mathrm{Mn}\left(\mathrm{R}_{226 \mathrm{Ra}-\mathrm{MnO}}=0.76\right)$. $\mathrm{U}$ concentrations on the other hand were correlated with those of $\mathrm{Fe}\left(\mathrm{R}_{\mathrm{U}-\mathrm{Fe} 2 \mathrm{O} 3}=0.75\right)$, As $\left(\mathrm{R}_{\mathrm{U}-\mathrm{As}}=0.80\right) \mathrm{Mn}\left(\mathrm{R}_{\mathrm{U}-\mathrm{MnO}}=0.81\right)$ and to a lesser extent with those of $\mathrm{Ca}\left(\mathrm{R}_{\mathrm{U}-\mathrm{CaO}}=0.70\right)$ and $\mathrm{S}\left(\mathrm{R}_{\mathrm{U}-\mathrm{S}}=0.68\right)$. They were also anticorrelated to $\mathrm{Si}\left(\mathrm{R}_{\mathrm{U}-\mathrm{SiO} 2}=-0.69\right)$ and Na $\left(\mathrm{R}_{\mathrm{U} \text { - }}\right.$ $\mathrm{Na} 2 \mathrm{O}=-0.61)$ concentrations. The observed correlations between the concentrations of $\mathrm{Mn}, \mathrm{U}$ and ${ }^{226} \mathrm{Ra}$ reflect the high affinity of these elements with respect to ferric oxyhydroxides $\left(\mathrm{R}_{\mathrm{Fe} 2 \mathrm{O} 3 \mathrm{-MnO}}=0.76\right.$ and $\left.\mathrm{R}_{\mathrm{Fe} 203-\mathrm{As}}=0.91\right)$. Thus, $\mathrm{Mn}$ would indicate the presence of ferric oxyhydroxides known for their retention properties for both As and Mn (Dzombak and Morel, 1990; Root et al., 2007).

These elemental correlations do not strictly allow to identify the $U$ and ${ }^{226} \mathrm{Ra}$ bearing minerals, as the volumes analyzed are too large to differentiate minerals unambiguously. It is more reasonable to attempt to associate $\mathrm{U}$ and ${ }^{226} \mathrm{Ra}$ with the two previously identified fractions, that is, on the one hand, the inherited fraction of the ore (predominantly $\mathrm{SiO}_{2}$ and $\mathrm{Na}_{2} \mathrm{O}$ ) and, on the other hand, the neo-formed fraction (enriched in $\mathrm{CaO}, \mathrm{S}, \mathrm{Fe}_{2} \mathrm{O}_{3}$ ). In this manner, ${ }^{226} \mathrm{Ra}$ appears to be preferentially in the neo-formed fraction while uranium, as confirmed by the results of the particle size characterization, appears to be in both fractions. 


\subsubsection{Chemical composition of each particle size fraction}

The majority of the particles had a size less than or equal to $400 \mu \mathrm{m}(91 \%$ by mass $)$ as shown in Figure SI-5. This result is consistent with the nature of dynamic process tailings, which are mainly composed of fine sands and fines (term used here to include silt and clay grades). This result should be considered as indicative because only one particle size analysis was conducted. Nevertheless, the study of the chemical composition of each granulometric class points to an enrichment of the smallest particle fractions with respect to LOI and Ca, S, Fe contents (LOI: from 12.7 to $17.4 \%$; $\mathrm{CaO}$ : from 1.83 to $6.60 \%$; $\mathrm{S}$ : from 0.65 to $3.48 \% ; \mathrm{Fe}_{2} \mathrm{O}_{3}$ : from 2.67 to $4.64 \%$ ) associated with a decrease in $\mathrm{Si}, \mathrm{Na}$ and $\mathrm{K}$ contents $\left(\mathrm{SiO}_{2}\right.$ : from 64.6 to $48.5 \%$; $\mathrm{Na}_{2} \mathrm{O}$ : from 1.57 to $1.24 \% ; \mathrm{K}_{2} \mathrm{O}$ : from 6.72 to $\left.4.70 \%\right)$, as observed in the overall analysis. The enrichments observed in $\mathrm{TiO}_{2}$ and $\mathrm{P}_{2} \mathrm{O}_{5}$ are interpreted as a small increase in heavy minerals such as titanium oxides and monazite. Elemental enrichment was also visible for $\mathrm{Ba}$ (from 781 to $1190 \mathrm{ppm}$ ) as well as ${ }^{226} \mathrm{Ra}$ (from 15.7 to $65.8 \mathrm{~Bq} / \mathrm{g}$ ). Uranium concentration was higher in the $2000 \mu \mathrm{m}$ fraction and to a lesser extent in the finest fraction. This results in a decrease in the $\left[{ }^{238} \mathrm{U}\right] /\left[{ }^{226} \mathrm{Ra}\right]$ activity ratio in the finest particle size fractions (from 0.29 to 0.05 ). These results, are interpreted as a concentration of ${ }^{226} \mathrm{Ra}$ mainly associated with barite type neo-formed or inherited reactive phases found in the finest fraction of the tailings dominated by gypsum while uranium is distributed within both fractions (inherited and neo-formed).

\subsubsection{Mineralogical characterizations}

Characterization by X-ray diffraction (XRD) confirmed the homogeneity of the set of samples which was consistent with the chemical characterizations. Representative diffractograms on total rock and fine fraction are presented in Figure 6. They underlined the presence principally of the minerals constituting the ore, namely quartz, potassium feldspar, plagioclases and micas, but also of the phases due to weathering of the ore (smectite, chlorite and kaolinite) and inherited from the milling process, such as gypsum. Iron oxides were observed in smaller quantities. Gypsum was not observed in the fraction below $2 \mu \mathrm{m}$. This is explained by the dissolution of this highly soluble mineral during the extraction of the fine fraction by wet process. The XRD did not detect any U-carrier phase.

Elemental and micromorphological observations using SEM (Figure 7) confirmed the results of the XRD characterizations. They highlighted the presence of the St-Sylvestre granite primary minerals, but also a fairly rapid diagenesis at the scale of the storage duration of the mill tailings. This was evidenced by the observation of weathering phases of inherited minerals such as the iron oxyhydroxides which had been neo-formed mainly within phyllosilicates (Figure 7). The accessory minerals were also visible at this scale of observation, namely zircons, barite, monazites and apatite-type rare earth phosphates. Occurrences of barite in the presence of neo-formed gypsum are neo-formed barite resulting from the neutralization slurries. This neo-formed barite coexists with inherited barites since the reference and the mineralized St-Sylvestre granites already contain significant levels of Ba in the form of barite (110 and 591 ppm respectively in the granites versus 839 ppm in the tailings samples) (Barbier and Ranchin, 1969).

The uranium carrier phases were mainly either of the uraninite or coffinite type, generally at the micrometer scale, preserved within resistant minerals (quartz) or accessory minerals such as phosphates and zircons. These were inherited phases that had withstood the milling process. Their dimensions were smaller than the release mesh produced by grinding at $450 \mu \mathrm{m}$. Micromorphological analysis also indicated that sulfide-type minerals were generally not accessible to fluids. 


\subsubsection{Evidence of the reactivity of clay minerals}

The mineralogical and elemental characterizations by XRD revealed the presence both of minerals inherited from the mineralized granites, and of sulfated, oxyhydroxide-type and also clayey neo-formed phases (in particular kaolinite and smectite). In this section, a focus is proposed on the neo-formation of clay minerals and their important $\mathrm{U}$ and ${ }^{226} \mathrm{Ra}$ retention properties (Schlegel and Descostes, 2009; Reinoso-Maset et al., 2012; Reinoso-Maset and Ly, 2014, 2016; Robin et al., 2017; Tayal et al., 2019).

The use of ternary diagrams makes it possible to highlight the weathering of feldspars (and micas) as well as the formation of kaolinite and smectite type clays and oxides using only the elemental concentrations determined in the solid samples. The poles $\mathrm{Al}_{2} \mathrm{O}_{3}-\left(\mathrm{CaO}+\mathrm{Na}_{2} \mathrm{O}\right)-\mathrm{K}_{2} \mathrm{O}$ commonly used (Nesbitt and Young, 1984) could not be used because of the presence of gypsum in the samples. For this reason, results were plotted in Figure 8 on a $\left(\mathrm{K}_{2} \mathrm{O}+\mathrm{Na}_{2} \mathrm{O}\right)$ - $\left(\left[\mathrm{Al}_{2} \mathrm{O}_{3}-\left(\mathrm{Na}_{2} \mathrm{O}+\mathrm{K}_{2} \mathrm{O}\right)\right] / 2\right)-\left(\left[\mathrm{Fe}_{2} \mathrm{O}_{3}+\mathrm{MgO}+\mathrm{MnO}\right] / 3\right)$ diagram allowing for the consideration of an alkaline pole (representing feldspars) - $(\mathrm{Na}, \mathrm{K}) \mathrm{AlSi}_{3} \mathrm{O}_{8}$ ), an aluminous pole (representative of kaolinite $-\mathrm{Si}_{2} \mathrm{O}_{5} \mathrm{Al}_{2}(\mathrm{OH})_{4}$ ) and finally a ferromagnesian pole (representative of micas - $\left.\mathrm{K}(\mathrm{Fe}, \mathrm{Mg})_{3} \mathrm{AlSi}_{3} \mathrm{O}_{10}(\mathrm{OH})_{2}\right)$. As a reminder, the weathering of feldspars and micas results in a depletion of alkaline elements ( $\mathrm{K}$ and $\mathrm{Na}$ ) and the formation of kaolinite and to a lesser extent smectite, schematically summarized below according to the respective balanced equations:

$$
\begin{aligned}
& 2 \mathrm{KAlSi}_{3} \mathrm{O}_{8}+9 \mathrm{H}_{2} \mathrm{O}+2 \mathrm{H}^{+} \rightarrow \mathrm{Si}_{2} \mathrm{O}_{5} \mathrm{Al}_{2}(\mathrm{OH})_{4}+4 \mathrm{H}_{4} \mathrm{SiO}_{4}+2 \mathrm{~K}^{+} \\
& 2,3 \mathrm{NaAlSi}_{3} \mathrm{O}_{8}+2 \mathrm{H}^{+} \rightarrow \mathrm{Na}_{0,3} \mathrm{Si}_{3,7} \mathrm{Al}_{0,3} \mathrm{O}_{10} \mathrm{Al}_{2}(\mathrm{OH})_{2}+3,2 \mathrm{H}_{4} \mathrm{SiO}_{4}+2 \mathrm{Na}^{+}+\mathrm{H}_{2} \mathrm{O} \\
& 2 \mathrm{~K}(\mathrm{Fe}, \mathrm{Mg})_{3} \mathrm{AlSi}_{3} \mathrm{O}_{10}(\mathrm{OH})_{2}+13 \mathrm{H}_{2} \mathrm{O}+2 \mathrm{H}^{+} \rightarrow \mathrm{Si}_{2} \mathrm{O}_{5} \mathrm{Al}_{2}(\mathrm{OH})_{4}+6(\mathrm{Fe}, \mathrm{Mg})(\mathrm{OH})_{2}+4 \mathrm{H}_{4} \mathrm{SiO}_{4}+2 \mathrm{~K}^{+}
\end{aligned}
$$

The data from the BZN tailings samples exhibited limited scatter, consistent with their homogeneity (Figure 8). Other analyses from samples from the St-Sylvestre massif are also documented (Boekhout et al., 2015; Kanzari et al., 2017). This is a non-weathered granite, an episyenite considered representative of the mineralizations, and a granitic waste rock subjected to varying stages of weathering since its first emplacement. In particular, the mineralogical and petrographic observations on these latter, more weathered samples, indicated the presence of smectite and kaolinite. The dots representing the tailings align well with the weathering profile ranging from the sound granites to the most weathered mine waste rock. They confirm the presence of clay minerals in greater quantities in the process tailings than in the ore.

The interpretation of the chemistry data led to consideration of the $\mathrm{U}$ within the minerals inherited from the ore, here in the form of uranium oxides and coffinite, but also within neo-formed minerals. As no uranium-carrying mineral phase was clearly identified, the presence of uranium sorbed to the surface of the smectite was investigated by TRLFS, a technique that can only detect the environments of U (VI). The superposition of the experimental spectra of the BZN_1_13.25-14.75m_2T sample with that acquired on the U-doped reference smectite confirmed the presence of $U$ also sorbed to the surface of the smectite (Figure 9). Uranium also has a high affinity for ferric oxyhydroxides. However, these phases could not be investigated because iron is known to inhibit U(VI) fluorescence. 
Two types of modeling were performed. Firstly, the distribution of $U$ and ${ }^{226} \mathrm{Ra}$ was investigated in order to describe the diagenesis conditions observed today. This modeling was carried out in static mode, i.e. by considering the physico-chemical equilibria (saturation indexes, SI) regulating the chemical composition of the porewaters in contact with the tailings. In a second step, the mobility of the $\mathrm{U}$ and ${ }^{226} \mathrm{Ra}$ was assessed using 1D reactive transport models simulating the long-term evolution of the tailings under leaching by inflow-water.

\subsection{Current distribution of $U$ and ${ }^{226} \mathrm{Ra}$}

On the basis of the characterizations of the porewaters and tailings, it was shown that the majority (more than 99\%) of the $\mathrm{U}$ and ${ }^{226} \mathrm{Ra}$ was trapped in the solid fraction (Figure 10). However, the geochemical and mineralogical study of tailings alone was often insufficient to identify the compartments carrying $U$ and ${ }^{226} \mathrm{Ra}$ within the tailings, and thus to assess their mobility. Moreover, there was no unambiguous marker for these compartments that would allow them to be easily identified and quantified. Microscopic observations revealed the presence of some resistant uranium minerals (uraninite and coffinite) trapped mainly within quartz. The additional characterizations by TRLFS allowed us to determine that a part of the $\mathrm{U}$ is also sorbed to the smectite. However, this technique did not allow the sorption of $\mathrm{U}$ to the HFOs to be evidenced. It was impossible to perform this type of analysis for ${ }^{226} \mathrm{Ra}$ because of its low elemental concentration ( 700 ppt). However, its speciation can be studied indirectly by sequential leaching. These complex experiments are subject to significant analytical bias. The compartments targeted are not completely independent of each other and there may be elemental recombination phenomena during a wash, leading to distortion in yield results (Bacon and Davidson, 2008). Therefore, thermodynamic equilibrium modeling was performed to study the distribution of $\mathrm{U}$ and ${ }^{226} \mathrm{Ra}$ in the BZN tailings.

The chemical composition of the porewater measured in the piezometer showed that the BZN tailings porewater was close to equilibrium with quartz polymorphs $(\mathrm{SI}=0.2)$, aluminosilicates and especially smectite $(\mathrm{SI}=0.1)$, calcite $(\mathrm{SI}=0.0)$, ferrihydrite $(\mathrm{SI}=-0.4)$ and gypsum $(\mathrm{SI}=-0.1)$, and slightly supersaturated with barite $(0.5)$. This is consistent with the mineralogy of the tailings previously described. The mineral assemblage composed of chalcedony (29\%), potassium feldspar (35\%), Ca-montmorillonite (25\%), ferrihydrite ( 0.6 to $1.1 \%$ as per model discussed in the paragraph below), gypsum (9\%), calcite (0.5\%), and barite $(0.15 \%)$, was used to describe the chemical reactivity of the solid-solution system within the BZN tailings throughout the interaction processes, and to simulate the chemical composition of the tailings porewater over time. The proportions of the mineral phases in the equilibrium assemblage were calculated from the elemental composition of the tailings. Thus, Si and Al were divided between clays, chalcedony, potassium feldspar (representing all the feldspars and muscovite) and the Ca-montmorillonite (representing all the clay minerals). $\mathrm{Mg}$ and $\mathrm{K}$ were attributed to the Ca-montmorillonite and potassium feldspar respectively. $\mathrm{Na}$ was artificially transferred to the sodium feldspars. $\mathrm{Fe}$ was attributed to ferrihydrite, while $\mathrm{S}$, Inorganic $\mathrm{C}$ and $\mathrm{Ba}$ were attributed to gypsum, calcite and barite respectively. Sorption of major elements and traces ( $\mathrm{U}$ and ${ }^{226} \mathrm{Ra}$ ) to the ferrihydrite and montmorillonite had also been taken into account in the reactive paragenesis. Thus, the calculated composition of the water in equilibrium with this mineralogical assemblage, given in Figure SI6and Table 1 was very close to that of the porewater analyzed.

The mean U concentration measured in the solid was $160 \mathrm{ppm}$, of which $83 \mathrm{ppm}$ (calculated with a yield of 95\% and an initial content of $1.66 \%$ ) could be borne by highly insoluble resistant phases as highlighted by the preceding 
mineralogical characterizations. Therefore, a low model (Min) taking into account the presence of resistant phases and a high model (Max) not taking them into account were presented. The only difference between these two models was the concentration of ferrihydrite. For the high model, the quantity of iron was carried exclusively by ferrihydrite while for the low model, the iron was distributed between pyrite $\left(\mathrm{FeS}_{2}\right)$ and ferrihydrite, respecting the sulfur balance. The quantity of ferrihydrite was $0.6 \%$ for the high model and $1.1 \%$ for the low model.

Thus, the speciation calculation carried out in the BZN porewaters indicated that uranium in solution was found exclusively in hexavalent form at a concentration of $1.2 \times 10^{-5} \mathrm{~mol} / \mathrm{L}$. Due to the high fugacity of $\mathrm{CO}_{2}$, carbonate complexes were in the majority $\left(\mathrm{UO}_{2}\left(\mathrm{CO}_{3}\right)_{3}{ }^{4-}: 78.5 \% ; \mathrm{UO}_{2}\left(\mathrm{CO}_{3}\right)_{2}{ }^{2-}: 21 \% ; \mathrm{UO}_{2} \mathrm{CO}_{3}: 0.5 \%\right)$. However, calciumuranyl-carbonate ternary complexes were not included in the model due to the high degree of uncertainty about their formation constant. Analysis of the saturation indices suggested that the $\mathrm{U}$ concentration was not constrained by any equilibrium with a pure mineral phase, as no uranium phase was in equilibrium. Therefore, surface sorption of clay minerals and HFOs was considered to explain the $\mathrm{U}$ concentrations measured in the solid fraction of the tailings and the porewaters in accordance with the mineralogical and TRLFS characterization. The amount of sorbed $U$ was calculated by considering water in equilibrium with reactive mineral paragenesis and including the sorption mechanisms. In this way, the concentration in the solid phase (in equilibrium with the imposed concentration in solution of $1.2 \times 10^{-5} \mathrm{~mol} / \mathrm{L}$ ) was correctly reproduced (160 ppm), of which 20 to $37 \%$ was sorbed to the clay minerals and 63 to $80 \%$ was sorbed to the HFOs (Figure 10) according to the model.

As with the $\mathrm{U}$, the specific activity of the ${ }^{226} \mathrm{Ra}$ present in the process-resistant phases was calculated and was approximately $1 \mathrm{~Bq} / \mathrm{g}$. The concentration in ${ }^{226} \mathrm{Ra}$, present at ultra-trace concentration in the environment, could not be constrained by the solubility of a pure ${ }^{226} \mathrm{Ra}$ phase. Therefore, other mechanisms such as the co-precipitation of ${ }^{226} \mathrm{Ra}$ in barite, sorption of ${ }^{226} \mathrm{Ra}$ to HFOs and clay minerals were taken into account in order to reproduce the ${ }^{226} \mathrm{Ra}$ specific activity in the solid. All of the ${ }^{226} \mathrm{Ra}$ and Ba present in the solid tailings were considered to be associated with the solid solution $(\mathrm{Ba}, \mathrm{Ra}) \mathrm{SO}_{4}$. Under these conditions, estimation of the ${ }^{226} \mathrm{Ra}$ concentration in porewater gave $0.68 \mathrm{~Bq} / \mathrm{L}$ (Table 1) while over $97.2 \%$ of the ${ }^{226} \mathrm{Ra}$ stock was associated with the solid solution of $(\mathrm{Ba}, \mathrm{Ra}) \mathrm{SO}_{4}$, with clay minerals and HFOs respectively accounting for $2.8 \%$ and $4.10^{-5} \%$ (Figure 10). Finally, the concentration of $\mathrm{SO}_{4}$ imposed by the solubility balance of gypsum explained the predominance of ${ }^{226} \mathrm{Ra}$ in the form of the aqueous complex $\mathrm{RaSO}_{4}$. The latter therefore promoted equilibrium with the solid solution (Ba, $\left.\mathrm{Ra}\right) \mathrm{SO}_{4}$.

These calculations confirmed the distribution of $\mathrm{U}$ and ${ }^{226} \mathrm{Ra}$ in the mill tailings, with over $99.9 \%$ of the $\mathrm{U}$ and the

${ }^{226} \mathrm{Ra}$ in the solid fraction, divided regardless of the model between the resistant minerals, the clay minerals, iron hydroxides, and, in the case of ${ }^{226} \mathrm{Ra}$, in the barite. The concentrations of $\mathrm{U}$ and ${ }^{226} \mathrm{Ra}$ in solution, reproduced according to the chemical equilibria with the minerals mentioned above, constituted a very small stock in the order of $10^{-4} \%$.

\subsection{Evolution of $U$ and ${ }^{226}$ Ra distribution over time}

A 1D reactive transport model to simulate the effect of percolation of granitic water within the tailings was run over a period of 230,000 years to evaluate the long-term reactivity of the $\mathrm{U}$ and ${ }^{226} \mathrm{Ra}$ and thus their mobility. 


\subsubsection{Evolution of the geochemical system}

The variations in the chemical composition of the different compartments (aqueous, surfaces and mineral phases) of the last cell of the column modeled during the percolation of the granitic water are presented in Figure 11.

The percolation of weakly mineralized granitic water within the Bellezane mill tailings led, as expected, to a significant decrease in the ionic strength of the porewater, down to an ionic strength of the same order of magnitude as that of the granitic waters (Figure 11a). The facies of the porewater, initially sulfated-magnesian, evolved as the equilibrium between the solid phase, the liquid phase, and the reactive surfaces changed and gradually converged with the facies of the percolating granitic water. The principal minerals from the mineral paragenesis did not undergo any significant dissolution or precipitation during the simulation period (Figure 11c). Only the gypsum and then the calcite were fully dissolved. The dissolution of the gypsum and the progressive dissolution of calcite led to a slight increase in pH from 6.3 to 7.2 (Figure 11b). In a second step, when the gypsum was completely dissolved (23,000 years), the $\mathrm{pH}$ increased to 8.5 for the entire calcite dissolution period, i.e. up to about 100,000 years, then reduced to a $\mathrm{pH}$ of around 6.6 at 150,000 years. This last decrease in $\mathrm{pH}$ was related to cation exchange reactions on the surface of clay minerals and more particularly to the preferential desorption of $\mathrm{Ca}$, resulting from the dissolution of the gypsum and calcite, to the detriment of protons (Figure 11d). Finally, this slow decrease in $\mathrm{pH}$ was explained by the low concentrations of major ions in granitic water, not allowing sufficiently rapid redistribution of the initially sorbed cation populations in favor of $\mathrm{H}^{+}, \mathrm{K}^{+}$and $\mathrm{Mg}^{2+}$. This was also verified to a lesser extent for the Ca sorbed to the ferric oxyhydroxides and also for the carbonates.

\subsubsection{Uranium mobility}

The modification of the chemical equilibria resulting from the percolation of granitic water within the tailings generated a redistribution of $U$ between the different compartments (sorption to clay minerals, sorption to iron oxyhydroxides, resistant uranium-bearing minerals, all of these minerals having been evidenced within the tailings). The evolution of this distribution within the last cell of the column over time is given in Figure 11e and for the two models previously discussed (low model and high model). The "total solid" part represents the sum of the fractions sorbed to the clay minerals and ferric hydroxides as well as the $\mathrm{U}$ contained in the resistant phases when these are taken into account (Min model).

Percolation of weakly mineralized granitic water with low uranium concentration within the BZN tailings was not sufficient to leach the uranium from the solid fraction, even if the uranium-bearing phases that were resistant to the process were not taken into account (low model), and despite the prevailing oxidizing conditions. Irrespective of the model considered, the $\mathrm{U}$ concentration in the solid was in the order of $160 \mathrm{ppm}$ throughout the simulation period and varied only slightly ( $1.8 \%$ decrease in the total amount of $U$ in the solid). The uranium was thus sequestered alternatively by two traps: sorption to ferrihydrite and sorption to clay minerals (Figure 1113f). U sorption to iron oxyhydroxides was predominant throughout the dissolution of gypsum and calcite (Figure 11c). The fraction sorbed to the iron oxyhydroxides then decreased as the $\mathrm{pH}$ decreased (Figure 11b) while the fraction sorbed to the clay minerals increased (Figure 11f). Therefore, as a function of $\mathrm{pH}$, the evolution of the sorbed $\mathrm{U}$ fractions was anticorrelated, the $\mathrm{U}$ being trapped alternatively on the iron oxy-hydroxides and clay minerals. The increase in $\mathrm{pH}$ and 
the increase in the concentration of calcium in solution generated inhibited the sorption of uranium to clay minerals during this period.

Dissolved U equilibrium concentrations decreased significantly in several stages in accordance with its retention on the iron oxyhydroxides and clay minerals. Thus, after a little over 150 years, concentrations reached $\sim 10^{-6} \mathrm{~mol} / \mathrm{L}$, then decreased during the gypsum dissolution phase $\left(\sim 8 \times 10^{-8} \mathrm{~mol} / \mathrm{L}\right.$ up to 23,000 years $)$, and again during the progressive dissolution of the calcite $\left(\sim 6 \times 10^{-8} \mathrm{~mol} / \mathrm{L}\right.$ up to 100,000 years; Figure $\left.11 \mathrm{e}\right)$. When all the calcite was dissolved and the $\mathrm{pH}$ was returned to $\mathrm{pH} 6.6$ (150,000 years), the dissolved $\mathrm{U}$ concentration was stabilized at $10^{-8}$ $\mathrm{mol} / \mathrm{L}$, which is close to the $\mathrm{U}$ concentration of the percolation solution.

\subsubsection{Radium 226 mobility}

Radioactive decay mainly governs the long-term evolution of ${ }^{226} \mathrm{Ra}$ mobility. The simulation period considered here, 230,000 years, goes well beyond ten radioactive periods of ${ }^{226} \mathrm{Ra}$. However, in order to better understand the role of each of the phases of ${ }^{226} \mathrm{Ra}$ sequestration, and to study the influence of ${ }^{226} \mathrm{Ra}$ in the percolation waters, several models were performed without taking into account the radioactive decay. The main results are also presented in Figures $11 \mathrm{~g}$ and $h$.

Whichever model is considered (e.g. Min model or Max model), the ${ }^{226} \mathrm{Ra}$ always remained sequestered over time. Indeed, the high sulfate concentration resulting from the dissolution of gypsum allowed the non dissolution of barite. However, the solid solution (Ba,Ra) $\mathrm{SO}_{4}$ entered equilibrium with the percolation water, showing a low level of ${ }^{226} \mathrm{Ra}$ activity. This therefore explained the decrease in the specific activity of the ${ }^{226} \mathrm{Ra}$ within the barite, in favor of sorption to the clay minerals (Figure 11h). Therefore, these retention mechanisms maintained a low aqueous concentration of ${ }^{226} \mathrm{Ra}$, systematically below that measured in this study $(<0.68 \mathrm{~Bq} / \mathrm{L})$ during 150,000 years $(\sim 100$ radioactive decay); see Figure $11 \mathrm{~g}$ for modeling results.

This mechanism was accelerated once the gypsum was completely dissolved (23,000 years), with $\mathrm{SO}_{4}$ concentrations no longer allowing the $\mathrm{RaSO}_{4}$ complex to be predominant and more conducive to the establishment of the solid solution $(\mathrm{Ba}, \mathrm{Ra}) \mathrm{SO}_{4}$. The aqueous concentration of ${ }^{226} \mathrm{Ra}$ became almost negligible. The decrease in $\mathrm{pH}$ to 6.6 after the complete dissolution of the calcite and the desorption of $\mathrm{Ca}^{2+}$ ions (150,000 years), also led to a slight desorption of ${ }^{226} \mathrm{Ra}$ which was in turn co-precipitated within the residual barite. The solid solution (Ba,Ra) $\mathrm{SO}_{4}$ again constrained the ${ }^{226} \mathrm{Ra}$ solution concentration, which then increased to values close to the concentrations initially observed $(\sim 1.4$ $\mathrm{Bq} / \mathrm{L})$.

Additional modeling was performed with percolation water not containing ${ }^{226} \mathrm{Ra}$. These models yielded the same results as those presented above (see Figure SI-7) indicating that the redistribution of ${ }^{226} \mathrm{Ra}$ and in particular its redissolution after 150,000 years was mainly governed by the initial source term here consisting of the mill tailings.

On this basis, the results of the modeling were then corrected for the radioactive decay for each compartment investigated (Figure 11i and j). As expected, ${ }^{226} \mathrm{Ra}$ activities decreased more rapidly, with a consistently verified distribution between barite and clay minerals and concentrations in solution in the order of natural background noise after three radioactive periods.

All these results (Figures 11g - 11j) indicated that the minerals with retention properties with respect to ${ }^{226} \mathrm{Ra}$, present in the ultra-trace concentration, were in surplus: barite, clay minerals and ferric hydroxides. The ${ }^{226} \mathrm{Ra}$ was easily 
trapped as a function of the chemical evolution of the system and in particular the $\mathrm{pH}$. When radioactive decay was taken into account, the specific activity of ${ }^{226} \mathrm{Ra}$ in the tailings was in the order of $1 \mathrm{~Bq} / \mathrm{g}$ from 5,000 years onwards, while the concentration in solution was less than $0.2 \mathrm{~Bq} / \mathrm{L}$ from 1,800 years onwards (Figures $11 \mathrm{i}$ and $11 \mathrm{j}$ ).

\section{Conclusions}

This multi-technical and multi-scalar study of the Bellezane mill tailings confirmed their chemical stability more than 25 years after emplacement thanks to rapid diagenesis. They remained homogeneous from the point of view of chemical, mineralogical and radiological composition. Indeed, the minerals inherited from the ore (quartz, potassic feldspar, plagioclases and micas) were observed in association with their initially present or neo-formed weathering products (mainly clay minerals such as smectite, chlorite and kaolinite as well as iron oxyhydroxides), and coexisting with neo-formed minerals following milling of the ore and neutralization of the tailings before their emplacement, such as in the case of gypsum (and to a lesser extent barite also present in the ore). All these minerals are effective traps for retention of $\mathrm{U}$ and ${ }^{226} \mathrm{Ra}$. The residual uranium $(160 \mathrm{ppm})$ and ${ }^{226} \mathrm{Ra}(25 \mathrm{~Bq} / \mathrm{g})$ in the solid phase after treatment represented in fact more than $99 \%$ of the total stock leading to concentrations in the porewaters of 12 $\mu \mathrm{mol} / \mathrm{L}$ and $0.58 \mathrm{~Bq} / \mathrm{L}$ respectively for $\mathrm{U}$ and ${ }^{226} \mathrm{Ra}$.

The long-term chemical reactivity of mill tailings could be described using a thermodynamic approach including solubility equilibria and also sorption and coprecipitation reactions in the case of ${ }^{226} \mathrm{Ra}$. The modeling carried out in this study confirmed the surplus presence of mineralogical traps (smectite, ferric oxyhydroxides and barite in the specific case of ${ }^{226} \mathrm{Ra}$ ) which, as the porewater chemistry evolves under the dissolution of gypsum and calcite, will maintain the concentrations of $U$ and ${ }^{226} \mathrm{Ra}$ in solution at low levels, even under oxidizing conditions, normally favorable to the migration of U(VI). In addition, the low permeability of the mill tailings stored within the former Bellezane open-pit mines led to mobility, in the case of the ${ }^{226} \mathrm{Ra}$, being governed mainly by radioactive decay, since the estimated flow rates within the tailings are in the region of $8.10^{-8} \mathrm{~m} \cdot \mathrm{s}^{-1}$.

These results will in the future be complemented by more detailed characterization of the tailings, in particular by Xray absorption spectroscopy and alpha autoradiography coupled with sequential leaching experimentation.

\section{Acknowledgements}

The authors would like to thank ORANO Mining's AMF department (Bessines sur Gartempe, France) for providing access to the Bellezane site and for their assistance in carrying out all the sampling work. Thanks also to Martine Gérard of IMPMC for her valuable expertise in the characterization of clay minerals.

\section{Bibliography}

Abdelouas, A., Lutze, W., Nuttall, E., 1998. Chemical reactions of uranium in ground water at a mill tailings site. J. Contam. Hydrol. 34, 343-361.

Ames, L.L., McGarrah, J.E., Walker, B.A., Salter, P.F., 1983a. Uranium and radium sorption on amorphous ferric oxyhydroxide. Chem. Geol. 40, 135-148. 
Ames, L.L., McGarrah, J.E., Walker, B.A., 1983b. Sorption of trace constituents from aqueous solutions onto secondary minerals. II. Radium. Clays Clay Miner. 31, 335-342.

Angileri, A., Sardini, P., Donnard, J., Duval, S., Lefeuvre, H., Oger, T., Patrier, P., Rividi, N., Siitari-Kauppi, M., Toubon, H., Descostes, M., 2018. Mapping ${ }^{238} \mathrm{U}$ decay chain equilibrium state in thin sections of geomaterials by digital autoradiography and microprobe analysis. Appl. Radiat. Isot. 140, 228-237.

AREVA, 2004. Bilan Décennal Environnemental 1994-2003.

ASN, 2019. https://www.asn.fr/Informer/Dossiers-pedagogiques/La-gestion-des-dechets-radioactifs/Plan-nationalde-gestion-des-matieres-et-dechets-radioactifs.Accessed the 05/08/2019.

Bachmaf, S., Merkel, B.J., 2011. Sorption of uranium (VI) at the clay mineral-water interface. Environ. Earth Sci. 63, 925-934.

Bacon, J.R., Davidson, C.M., 2008. Is there a future for sequential chemical extraction? Analyst 133, 25-46.

Ballini, M., 2017. Caractérisation et réactivité des résidus de traitement issus de l'exploitation des minerais d'uranium en France (Lavaugrasse, Bellezane, Ribière, Cellier). Projet Envir@mines - PNGMDR 3. Mobilité de l'uranium et du radium 226 dans les résidus de traitement de Bellezane - Construction du modèle géochimique. Technical report AREVA No. AMS-DOP-DRD-NT-0127.

Ballini, M., Nos, J., Phrommavanh, V., Descostes, M., 2017. U and ${ }^{226}$ Ra mobility in the uranium mill tailings of Bellezane (France). Proceedings of the Goldschmidt Conference, $13^{\text {th }} 18^{\text {th }}$ July, Paris, France, Goldschmidt Abstracts 2017, p. 218.Barbier, J., Ranchin, G., 1969. Influence de l'altération météorique sur l'uranium à l'état de traces dans le granite à deux micas de St-Sylvestre. Geochim. Cosmochim. Acta 33, 39-47.

Bavoux, B., Guiollard, P.C., 2003. The Uranium of la Crouzille (Haute-Vienne). Pierre-Christian Guiollard Auteur Editeur.

Bethke, C.M., 2007. Geochemical and biogeochemical reaction modeling. Cambridge University Press.

Boekhout, F., Gérard, M., Kanzari, A., Michel, A., Déjeant, A., Galoisy, L., Calas, G., Descostes, M., 2015. Uranium migration and retention during weathering of a granitic waste rock pile. Appl. Geochem. 58, 123-135.

Bordelet, G., Beaucaire, C., Phrommavanh, V., Descostes, M., 2018. Chemical reactivity of natural peat towards U and Ra. Chemosphere 202, 651-660.

Brandt, F., Curti, E., Klinkenberg, M., Rozov, K., Bosbach, D., 2015. Replacement of barite by a (Ba, Ra) $\mathrm{SO}_{4}$ solid solution at close-to-equilibrium conditions: A combined experimental and theoretical study. Geochim. Cosmochim. Acta 155, 1-15.

Catalano, J.G., Brown Jr, G.E., 2005. Uranyl adsorption onto montmorillonite: Evaluation of binding sites and carbonate complexation. Geochim. Cosmochim. Acta 69, 2995-3005.

Chautard, C., Beaucaire, C., Gérard, M., Phrommavanh, V., Nos, J., Galoisy, L., Calas, G., Roy, R., Descostes, M., 2017. Geochemical characterization of U tailings (Bois Noirs Limouzat, France). Procedia Earth Planet. Sci. 17, 308-311.

Cretaz, F., Szenknect, S., Clavier, N., Vitorge, P., Mesbah, A., Descostes, M., Poinssot, C., Dacheux, N., 2013. Solubility properties of synthetic and natural meta-torbernite. J. Nucl. Mater. 442, 195-207.

Cumberland, S.A., Douglas, G., Grice, K., Moreau, J.W., 2016. Uranium mobility in organic matter-rich sediments: a review of geological and geochemical processes. Earth-Sci. Rev. 159, 160-185.

Curti, E., Fujiwara, K., Iijima, K., Tits, J., Cuesta, C., Kitamura, A., Glaus, M., Müller, W., 2010. Radium uptake during barite recrystallization at $23 \pm 2 \mathrm{C}$ as a function of solution composition: An experimental ${ }^{133} \mathrm{Ba}$ and ${ }^{226} \mathrm{Ra}$ tracer study. Geochim. Cosmochim. Acta 74, 3553-3570.

Déjeant, A., Bourva, L., Sia, R., Galoisy, L., Calas, G., Phrommavanh, V., Descostes, M., 2014. Field analyses of ${ }^{238} \mathrm{U}$ and ${ }^{226} \mathrm{Ra}$ in two uranium mill tailings piles from Niger using portable HPGe detector. J. Environ. Radioact. 137, 105-112.

Déjeant, A., Galoisy, L., Roy, R., Calas, G., Boekhout, F., Phrommavanh, V., Descostes, M., 2016. Evolution of uranium distribution and speciation in mill tailings, COMINAK Mine, Niger. Sci. Total Environ. 545-546, 340-352.

Descostes, M., Boizard, A., Nos, J., Peiffert, C., Cathelineau, M., Phrommavanh, V., 2013. Caractérisation des résidus de traitement issus de l'exploitation des minerais d'uranium en France (Lavaugrasse, Bellezane, Ribière, Cellier) - Projet Envir@Mines - PNGMDR2. Technical report AREVA No. AMS-DEXP-DRD-RT0002.

Donahue, R., Hendry, M., Landine, P., 2000. Distribution of arsenic and nickel in uranium mill tailings, Rabbit Lake, Saskatchewan, Canada. Appl. Geochem. 15, 1097-1119. 
Dzombak, D.A., Morel, F., 1990. Surface complexation modeling: hydrous ferric oxide. John Wiley \& Sons.

Essilfie-Dughan, J., Pickering, I.J., Hendry, M.J., George, G.N., Kotzer, T., 2010. Molybdenum speciation in uranium mine tailings using X-ray absorption spectroscopy. Environ. Sci. Technol. 45, 455-460.

Fatmi, H., Ababou, R., Matray, J., 2008. Statistical pre-processing and analyses of hydro-meteorological time series in a geologic clay site (methodology and first results for Mont Terri's PP experiment). Phys. Chem. Earth Parts ABC 33, S14-S23.

Fernandes, H.M., Franklin, M.R., Veiga, L.H., Freitas, P., Gomiero, L.A., 1996. Management of uranium mill tailing: geochemical processes and radiological risk assessment. J. Environ. Radioact. 30, 69-95.

GEP, Groupe d'Expertise Pluraliste, 2010. Report GT2 by the pluralistic expertise group on the Limousin uranium mining sites. Volumes 1 and 2: Environmental, ecosystem and health controls Environmental risk Dose and health impacts. France. INIS-FR- -11-0491 (https://inis.aiea.org).

Jones, M.J., Butchins, L.J., Charnock, J.M., Pattrick, R.A., Small, J.S., Vaughan, D.J., Wincott, P.L., Livens, F.R., 2011. Reactions of radium and barium with the surfaces of carbonate minerals. Appl. Geochem. 26, 12311238.

Kanzari, A., Gérard, M., Boekhout, F., Galoisy, L., Calas, G., Descostes, M., 2017. Impact of incipient weathering on uranium migration in granitic waste rock piles from former $\mathrm{U}$ mines (Limousin, France). J. Geochem. Explor. 183, 114-126.

Landa, E.R., 2004. Uranium mill tailings: nuclear waste and natural laboratory for geochemical and radioecological investigations. J. Environ. Radioact. 77, 1-27.

Langmuir, D., 1978. Uranium solution-mineral equilibria at low temperatures with applications to sedimentary ore deposits. Geochim. Cosmochim. Acta 42, 547-569.

Langmuir, D., Riese, A.C., 1985. The thermodynamic properties of radium. Geochim. Cosmochim. Acta 49, $1593-$ 1601.

Ledoux, E., Schmitt, J.-M., 2010. Étude du fonctionnement hydrogéochimique de l'ancien site minier de Bellezane (Limousin, France). Technical report AREVA Mines / No R100119EL, BGM/DGS RT 10/004, Centre de Géosciences, École des Mines de Paris, Fontainebleau, France.

Lestini, L., Beaucaire, C., Vercouter, T., Ballini, M., Descostes, M., 2019. Role of trace elements in the 226-radium incorporation in sulfate minerals (gypsum and celestite). ACS Earth Space Chem. 3, 295-304.

Liu, B., Peng, T., Sun, H., Yue, H., 2017. Release behavior of uranium in uranium mill tailings under environmental conditions. J. Environ. Radioact. 171, 160-168.

Mahoney, J.J., Cadle, S.A., Jakubowski, R.T., 2009. Uranyl adsorption onto hydrous ferric oxide. A re-evaluation for the diffuse layer model database. Environ. Sci. Technol. 43, 9260-9266.

Martin, A., Crusius, J., McNee, J.J., Yanful, E., 2003. The mobility of radium-226 and trace metals in pre-oxidized subaqueous uranium mill tailings. Appl. Geochem. 18, 1095-1110.

Moldovan, B.J., Jiang, D., Hendry, M.J., 2003. Mineralogical characterization of arsenic in uranium mine tailings precipitated from iron-rich hydrometallurgical solutions. Environ. Sci. Technol. 37, 873-879.

Molinari, J., Snodgrass, W., 1990. The chemistry and radiochemistry of radium and the other elements of the uranium and thorium natural decay series. Environ. Behav. Radium 1, 11-56.

Murakami, T., Ohnuki, T., Isobe, H., Sato, T., 1997. Mobility of uranium during weathering. Am. Mineral. 82, 888899.

Nesbitt, H.W., Young, G., 1984. Prediction of some weathering trends of plutonic and volcanic rocks based on thermodynamic and kinetic considerations. Geochim. Cosmochim. Acta 48, 1523-1534.

Nirdosh, I., Muthuswami, S., Baird, M., 1984. Radium in uranium mill tailings-some observations on retention and removal. Hydrometallurgy 12, 151-176.

Nos, J., Boizard, A., Peiffert, C., Cathelineau, M., Phrommavanh, V., Descostes, M., 2014. Caractérisation et réactivité des résidus de traitement issus de l'exploitation des minerais d'uranium en France (Lavaugrasse, Bellezane, Ribière, Cellier). Projet Envir@Mines - PNGMDR 2. Technical report AREVA No. AMSDEXP-DRD-RT-0039.

Nos, J., Boizard, A., Phrommavanh, V., Cathelineau, M., Descostes, M., 2013. Geochemical characterization of uranium mill tailings. Mineralogical Magazine 77(5), 1863.Othmane, G., Allard, T., Vercouter, T., Morin, G., Fayek, M., Calas, G., 2016. Luminescence of uranium-bearing opals: Origin and use as a pH record. Chem. Geol. 423, 1-6. 
Parkurst, D., Appelo, C., 1999. User's guide to PHREEQC (version 2)-a computer program for speciation, batchreaction, one dimensional transport, and inverse geochemical calculations. U.S. Geological Survey Water Resour. Investig. Rep. 994259.

Paucard, A., 2007. La mine et les mineurs de l'Uranium français. Editions T. Parquet.

Reinoso-Maset, E., Hainos, D., Ly, J., 2012a. Sorption of uranium (VI) and radium (II) at trace level onto kaolinite and montmorillonite. Mineralogical Magazine 76(6), 2275. Reinoso-Maset, E., Hainos, D., Ly, J., 2012b. Personal communication.

Reinoso-Maset, E., Ly, J., 2014. Study of major ions sorption equilibria to characterize the ion exchange properties of kaolinite. J. Chem. Eng. Data 59, 4000-4009.

Reinoso-Maset, E., Ly, J., 2016. Study of uranium (VI) and radium (II) sorption at trace level on kaolinite using a multisite ion exchange model. J. Environ. Radioact. 157, 136-148.

Robertson, J., Hendry, M.J., Kotzer, T., Hughes, K.A., 2019. Geochemistry of uranium mill tailings in the Athabasca Basin, Saskatchewan, Canada: A review. Crit. Rev. Environ. Sci. Technol. 1-57.

Robin, V., Tertre, E., Beaucaire, C., Regnault, O., Descostes, M., 2017. Experimental data and assessment of predictive modeling for radium ion-exchange on beidellite, a swelling clay mineral with a tetrahedral charge. Appl. Geochem. 85, 1-9.

Root, R.A., Dixit, S., Campbell, K.M., Jew, A.D., Hering, J.G., O’Day, P.A., 2007. Arsenic sequestration by sorption processes in high-iron sediments. Geochim. Cosmochim. Acta 71, 5782-5803.

Sajih, M., Bryan, N., Livens, F., Vaughan, D., Descostes, M., Phrommavanh, V., Nos, J., Morris, K., 2014. Adsorption of radium and barium on goethite and ferrihydrite: A kinetic and surface complexation modelling study. Geochim. Cosmochim. Acta 146, 150-163.

Sardini, P., Angileri, A., Descostes, M., Duval, S., Oger, T., Patrier, P., Rividi, N., Siitari-Kauppi, M., Toubon, H., Donnard, J., 2016. Quantitative autoradiography of alpha particle emission in geo-materials using the Beaver ${ }^{\mathrm{TM}}$ system. Nucl. Instrum. Methods Phys. Res. Sect. Accel. Spectrometers Detect. Assoc. Equip. 833, $15-22$.

Scaillet, S., Cheilletz, A., Cuney, M., Farrar, E., Archibald, D.A., 1996. Cooling pattern and mineralization history of the Saint Sylvestre and western Marche leucogranite pluton, French Massif Central: I. ${ }^{40} \mathrm{Ar} /{ }^{39} \mathrm{Ar}$ isotopic constraints. Geochim. Cosmochim. Acta 60, 4653-4671.

Scheinost, A.C., Hennig, C., Somogyi, A., Martinez-Criado, G., Knappik, R., 2006. Uranium speciation in two Freital mine tailing samples: EXAFS, $\mu$-XRD, and $\mu$-XRF results, in: Uranium in the Environment. Springer, pp. $117-126$.

Schlegel, M.L., Descostes, M., 2009. Uranium uptake by hectorite and montmorillonite: a solution chemistry and polarized EXAFS study. Environ. Sci. Technol. 43, 8593-8598.

Somot, S., Pagel, M., Thiry, J., 1997. Spéciation du radium dans les résidus de traitement acide du minerai d'uranium de l'Écarpière (Vendée, France). Comptes Rendus Académie Sci.-Ser. IIA-Earth Planet. Sci. 325, 111-118.

Somot, S., Pagel, M., Thiry, J., Ruhlmann, F., 2000. Speciation of ${ }^{226} \mathrm{Ra}$, uranium and metals in uranium mill tailings. Proceedings of the Seventh International Conference on Tailings and Mine Waste'00. Ft. Collins, Colorado, Balkema, Rotterdam, pp. 343-352.

\#Tachi, Y., Shibutani, T., Sato, H., Yui, M., 2001. Experimental and modeling studies on sorption and diffusion of radium in bentonite. J. Contam. Hydrol. 47, 171-186.

Tayal, A., Conradson, S.., Kanzari, A., Lahrouch, F., Descostes, M., Gérard, M., 2019. Determination of the speciation of $\mathrm{U}$ in granitic waste rock piles from Limousin France, by X-ray Absorption Fine Structure spectroscopy. RSC Advances 9 11762-11773.

Vercouter, T., Vors, E., Sirven, J.-S., Lecointe, M., Szenknect, S., Wattinne, A., Descostes, M., 2017. Direct detection and identification of Uranium(VI)-bearing solids by TRLFS and chemometrics analysis. Migration, $16^{\text {th }}$ International Conference on the Chemistry and Migration Behaviour of Actinides and Fission Products in the Geosphere, Barcelona, Spain, September $10^{\text {th }}-15^{\text {th }}$.

Vinograd, V., Brandt, F., Rozov, K., Klinkenberg, M., Refson, K., Winkler, B., Bosbach, D., 2013. Solid-aqueous equilibrium in the $\mathrm{BaSO}_{4}-\mathrm{RaSO}_{4}-\mathrm{H}_{2} \mathrm{O}$ system: first-principles calculations and a thermodynamic assessment. Geochim. Cosmochim. Acta 122, 398-417.

Waite, T., Davis, J., Payne, T., Waychunas, G., Xu, N., 1994. Uranium (VI) adsorption to ferrihydrite: Application of a surface complexation model. Geochim. Cosmochim. Acta 58, 5465-5478.

Walter, M., Arnold, T., Reich, T., Bernhard, G., 2003. Sorption of uranium (VI) onto ferric oxides in sulfate-rich acid waters. Environ. Sci. Technol. 37, 2898-2904. 
865 WNA, 2019. http://www.world-nuclear.org/information-library/nuclear-fuel-cycle/mining-of-uranium/world866 uranium-mining-production.aspx. Accessed the 16/05/2019.

867 Yan, X., Luo, X., 2015. Radionuclides distribution, properties, and microbial diversity of soils in uranium mill 868 tailings from southeastern China. J. Environ. Radioact. 139, 85-90.

869 Zhang, T., Gregory, K., Hammack, R.W., Vidic, R.D., 2014. Co-precipitation of radium with barium and strontium 870 sulfate and its impact on the fate of radium during treatment of produced water from unconventional gas extraction. Environ. Sci. Technol. 48, 4596-4603. 


\section{Figure and Table captions}

878 Figure 1. Mean elemental concentrations (ppm) of BZN tailings compared to mineralized and non-mineralized St-Sylvestre granite (data according to Boekhout et al. (2015) and Kanzari et al. (2015)).

Figure 2. Bellezane site in (a) operation, (b) during backfilling of pits MCO 105 and 68 with tailings (red color), and (c) after remediation. Tailings core collected during this study in (d). The location of the BZN 1 borehole in the MCO 105 pit is given in (c).

Figure 3. Dose rate measured on core as a function of depth. The grey dots represent the samples that have undergone full characterization.

Figure 4. Elemental chemical composition of BZN tailings, $[\mathrm{U}]$ solid, $\left[{ }^{238} \mathrm{U}\right]_{\text {solid }} /\left[{ }^{226} \mathrm{Ra}\right]_{\text {solid }}$ mass activity ratio and $\left[{ }^{226} \mathrm{Ra}\right]_{\text {solid }}$ as a function of depth.

Figure 5. Molar concentrations of S and TIC as a function of molar concentrations of $\mathrm{Ca}$ (a). Elemental correlation in $\mathrm{S}$ and loss on ignition (LOI) in samples (b).

887 Figure 6. (a) Comparisons of X ray diffraction patterns of the bulk and the clay fraction $(<2 \mu \mathrm{m})$ and (b) clay mineralogy on oriented air-dried, glycolated and heated of tailing sample BZN_1_13.25-14.75m_3T. Abbreviations: Sm: smectite, Chl: Chlorite, G: Gypsum, K: Kaolinite, M: Mica, Q: Quartz, Kf: K-felspar, Pl: Plagioclase, Fe ox: Fe oxide, Px: Pyroxene.

Figure 7. SEM images of Bellezane tailings. In the center, an overall view completed by details of inherited phases and secondary phases (inherited and/or neo-formed) on powder or thin sections. Phases were identified by SEM-EDX (EDX spectra not shown).

Figure 8. Ternary diagram $\left(\mathrm{K}_{2} \mathrm{O}+\mathrm{Na} \mathrm{N}_{2} \mathrm{O}\right)-\left(\left[\mathrm{Al}_{2} \mathrm{O}_{3}-\left(\mathrm{Na}_{2} \mathrm{O}+\mathrm{K}_{2} \mathrm{O}\right)\right] / 2\right)-\left(\left[\mathrm{Fe}_{2} \mathrm{O}_{3}+\mathrm{MgO}+\mathrm{MnO}\right] / 3\right)$ showing the weathering of feldspars to clay minerals in BZN samples. Additional data from Boekhout et al. (2015) and Kanzari et al. (2017) for waste rocks are also plotted..

Figure 9. TRLFS spectra of a BZN sample (BZN_1_13.25-14.75m_2T) and a smectite doped with sorbed uranium.

Figure 10. Distribution of $U$ and ${ }^{226} \mathrm{Ra}$ within the mill tailings and according to the Min and Max models developed in this study. The Min model considers that a fraction of the radioelement is trapped in phases inherited from the ore that are considered non-reactive. The Max model considers all the radioelements as reactive.

Figure 11. Long term reactivity model for the evolution of (a) ionic strength, (b) $\mathrm{pH}$, (c) principal minerals, (d) cationic populations sorbed to the surface of clay minerals (Min model; sorbed Na was too low to appear in the scale), (e) aqueous $\mathrm{U}$, (f) U in solid, (g) aqueous ${ }^{226} \mathrm{Ra}$ without taking into consideration radioactive decay, (h) ${ }^{226} \mathrm{Ra}$ in solid without taking into consideration radioactive decay, (i) aqueous ${ }^{226} \mathrm{Ra}$ taking into consideration radioactive decay, and (j) ${ }^{226} \mathrm{Ra}$ in solid taking into consideration radioactive decay (a time scale change was done on $7.5 \mathrm{x}{ }^{226} \mathrm{Ra}$ radioactive decay). The Max model does not take into account the presence of refractory phases. For the Min model, the $\mathrm{U}$ and ${ }^{226} \mathrm{Ra}$ contents of the refractory phases have been added to the total solid part on graphs (f), (h) and (j).

Table 1. Chemical composition of the ES85 porewater solution (measured and modeled) and the granitic water (ES60; from Ledoux and Schmitt, 2010) percolating in the tailings column. All the concentrations are given in mol/L, except ${ }^{226} \mathrm{Ra}$ concentration in $\mathrm{Bq} / \mathrm{L}$.

\section{Supplementary Information Figure and Table captions}

Figure SI-1. Location of the La Crouzille mining division, its mining operations, and the Bellezane Tailings Management Facility (GEP, 2010).

Figure SI-2. Correlation between the piezometric height measured at ES85 and atmospheric pressure (Ledoux and Schmitt, 2010).

Figure SI-3. Cumulative number of samples as a function of depth. The grey dots represent the samples that have undergone full characterization. 
912 Figure SI-4. Ratios of concentrations measured in the porewater fraction filtered at $10 \mathrm{kDa}$ and $0.2 \mu \mathrm{m}$, sampled in piezometer ES85.

913 Figure SI-5. Particle size distribution (a), $\left[{ }^{238} \mathrm{U}\right] /\left[{ }^{226} \mathrm{Ra}\right]$ mass activity ratio (b), major (c) and trace (d) element concentrations in each of the

914 particle size fractions of sample BZN_1_13.25-14.75m_2T. The concentrations of major and trace elements in each particle size fraction are

915 normalized with those measured in the $2000 \mu \mathrm{m}$ fraction.

916 Figure SI-6. Comparison between measured and modeled ES85 porewater concentrations.

917 Figure SI-7. Evolution of aqueous ${ }^{226} \mathrm{Ra}$ without taking into account the radioactive decay (a), and ${ }^{226}$ Ra in the solid without taking into account

918 the radioactive decay (b) and considering a percolation water without ${ }^{226} \mathrm{Ra}$. Values with radioactive decay are shown in light grey on both 919 figures.

920 Table SI-1. Summary of the characterization analyses carried out for all the samples studied.

921 Table SI-2. Sorption constants of $\mathrm{U},{ }^{226} \mathrm{Ra}$ and $\mathrm{CO}_{3}{ }^{2-}$ on ferrihydrite added to the PHREEQC database (_w and _s stands for weak and strong 922 binding sites respectively).

923 Table SI-3. Site concentration and selectivity coefficients of cation exchange reactions for montmorillonite (Gaines-Thomas convention)

924 (Reinoso-Maset et al., 2012a and 2012b).

925 Table SI-4. Mean $\left(\mathrm{C}_{\text {mean }}\right)$, minimum $\left(\mathrm{C}_{\min }\right)$ and maximum $\left(\mathrm{C}_{\max }\right)$ elemental levels measured in BZN samples. Mean values are accompanied

926 by the standard deviations. Corg and LOI denote organic $\mathrm{C}$ content and loss on ignition respectively.

927 Table SI-5. Trace-level element concentrations measured in mill tailings samples (D. L. stands for detection limit).

928 Table SI-6. Elemental correlations calculated from the chemical and radiological characterizations of the mill tailings. 


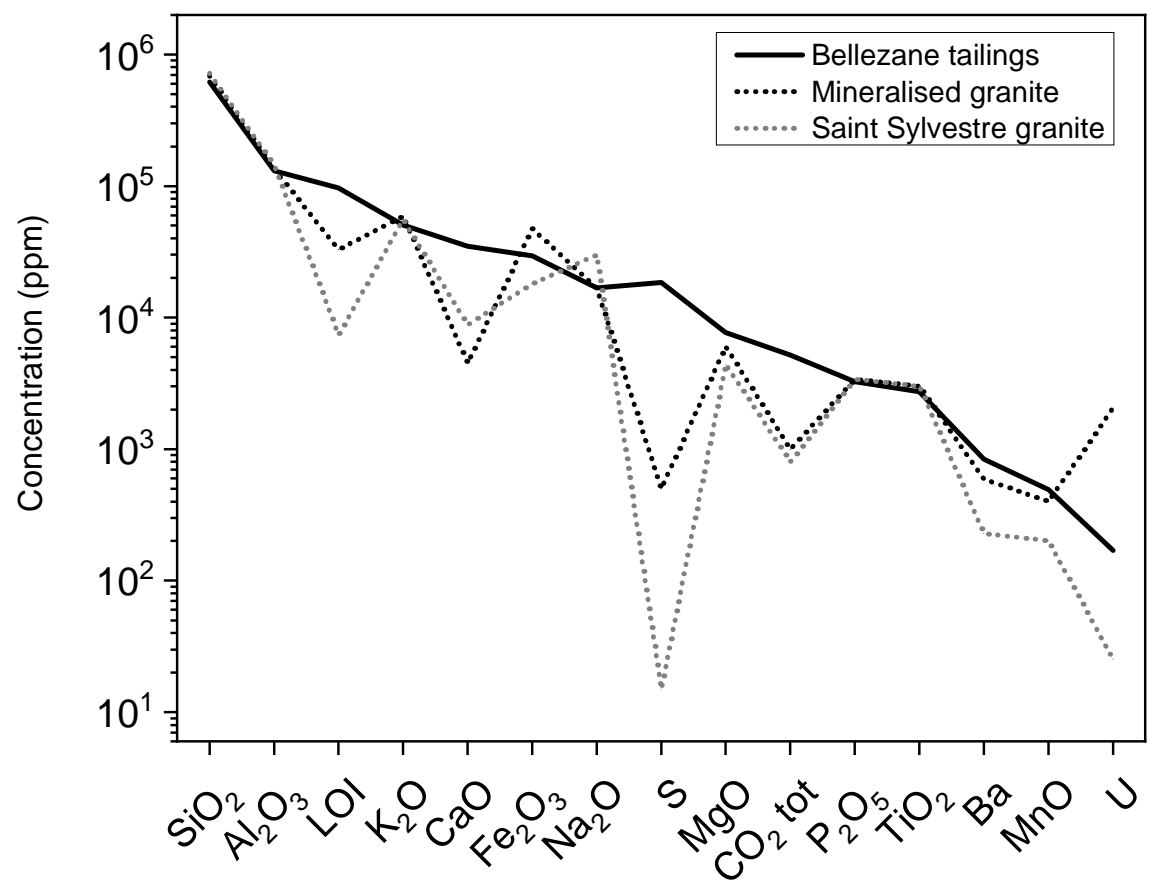

Figure 1. Mean elemental concentrations (ppm) of BZN tailings compared to mineralized and non-mineralized St-Sylvestre granite (data according to Boekhout et al. (2015) and Kanzari et al. (2017)). 

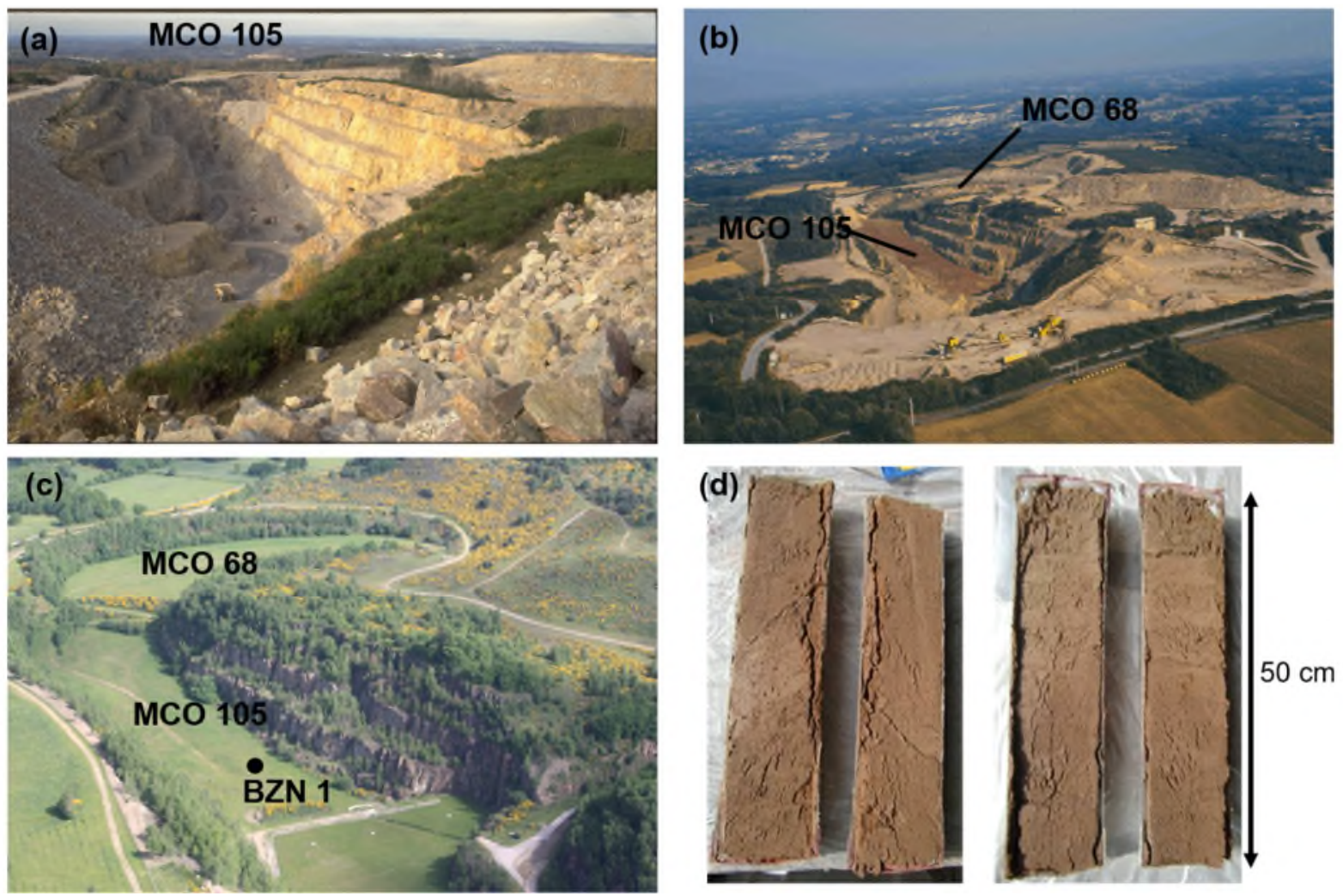

Figure 2. Bellezane site in (a) operation, (b) during backfilling of pits MCO 105 and 68 with tailings (red color), and (c) after remediation (c). Tailings core collected during this study (d). The location of the BZN 1 borehole in the MCO 105 pit is given in (c). 


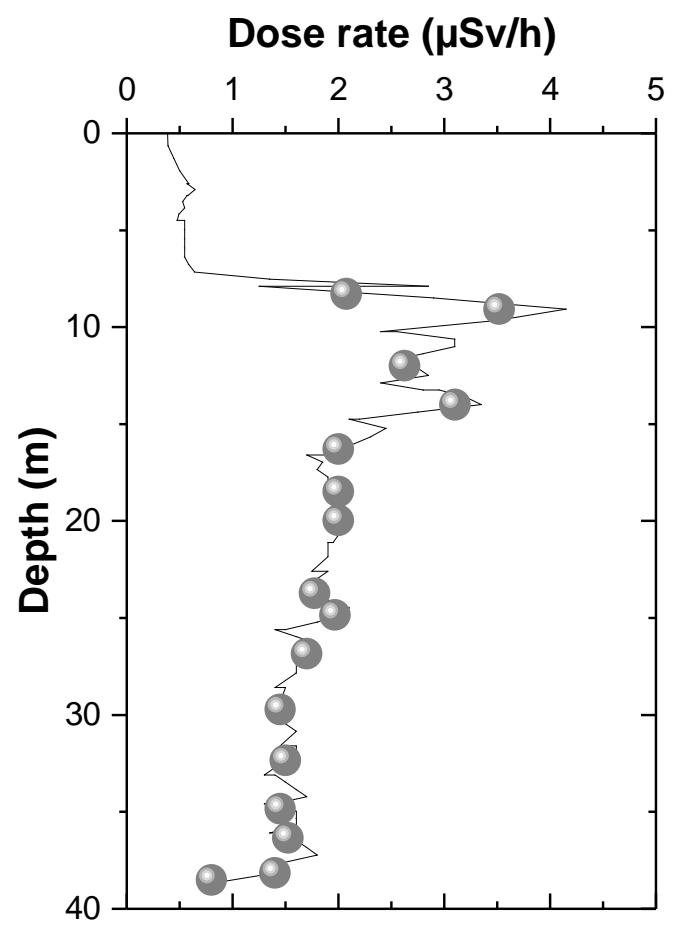

Figure 3. Dose rate measured on core as a function of depth. The grey dots represent the samples that have undergone full characterization. 


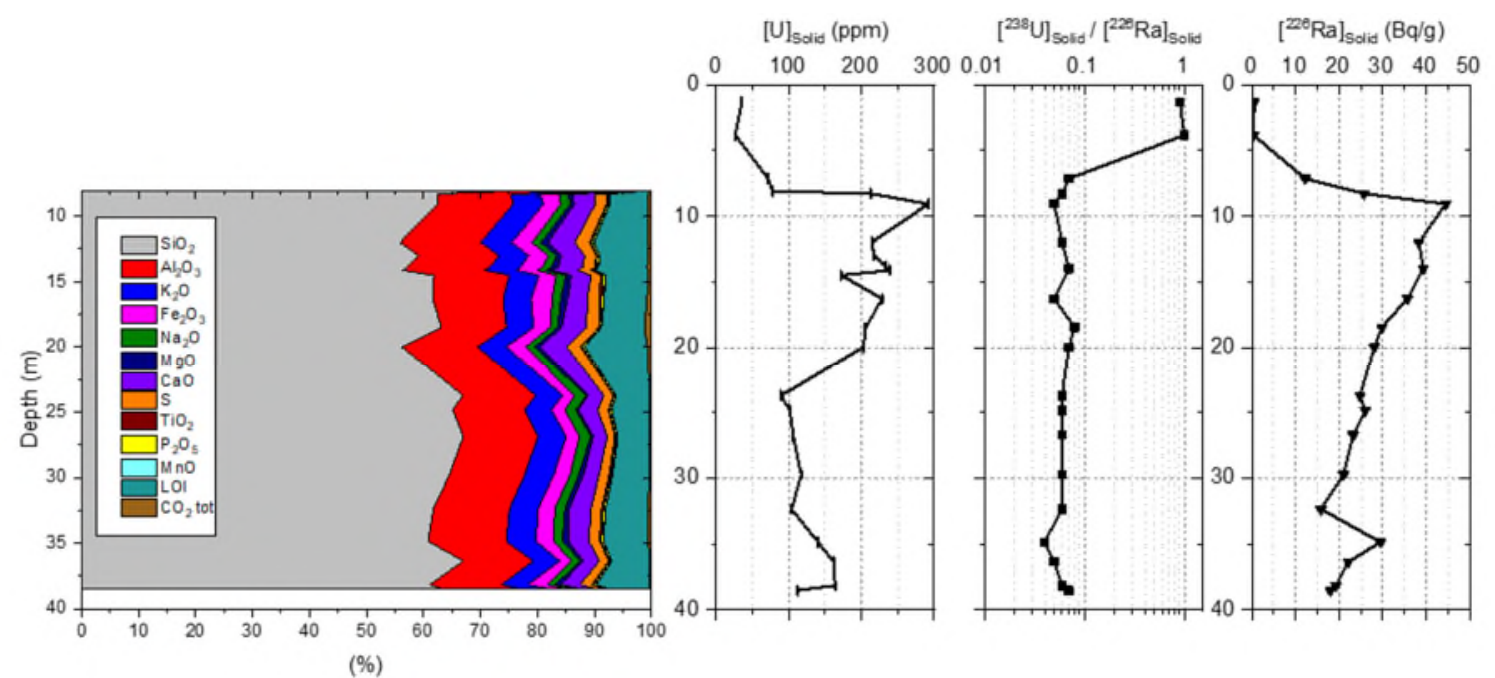

Figure 4. Elemental chemical composition of BZN tailings, $[\mathrm{U}]_{\text {solid }},\left[{ }^{238} \mathrm{U}\right]_{\text {solid }} /\left[{ }^{226} \mathrm{Ra}\right]_{\text {solid }}$ mass activity ratio and $\left[{ }^{226} \mathrm{Ra}\right]_{\text {solid }}$ as a function of depth. 

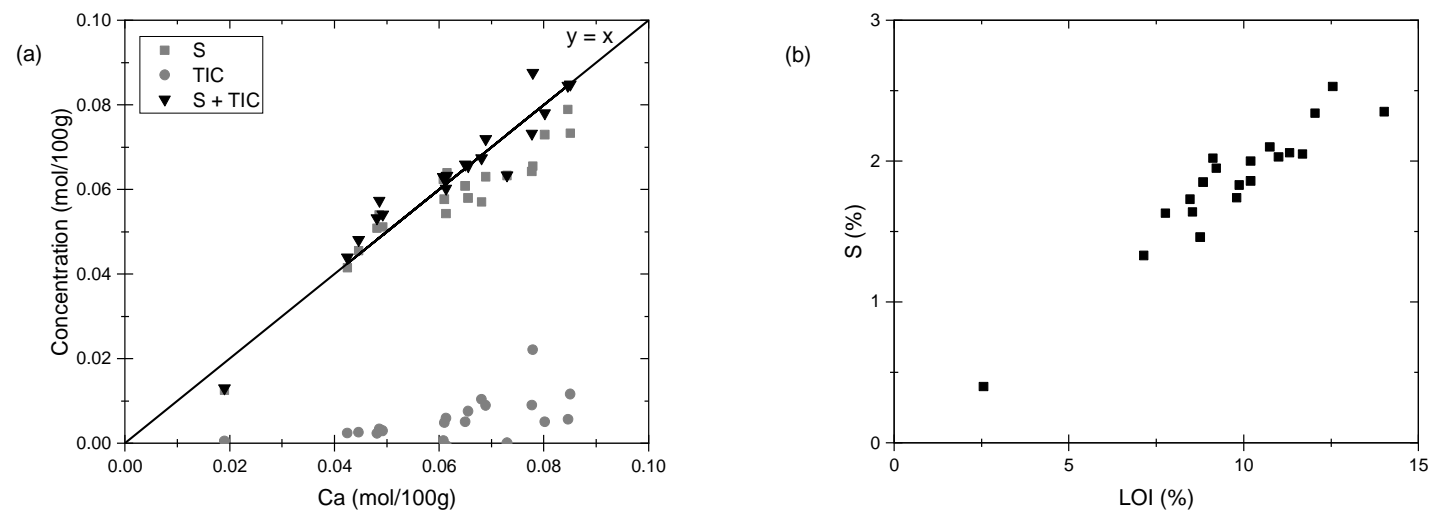

Figure 5. Molar concentrations of S and TIC as a function of molar concentrations of Ca (a). Elemental correlation in S and loss on ignition (LOI) in samples (b). 
(a)

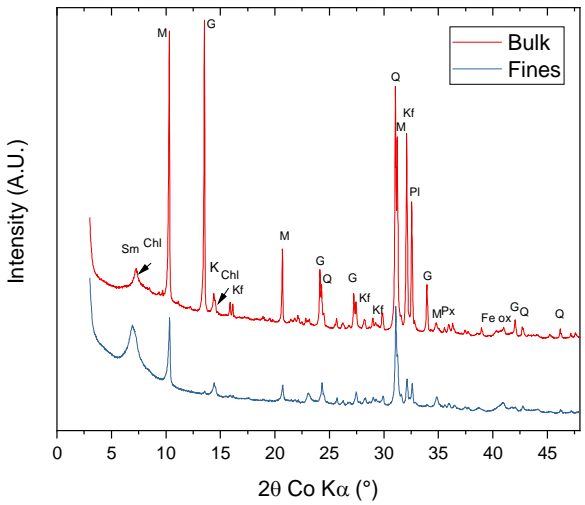

(b)

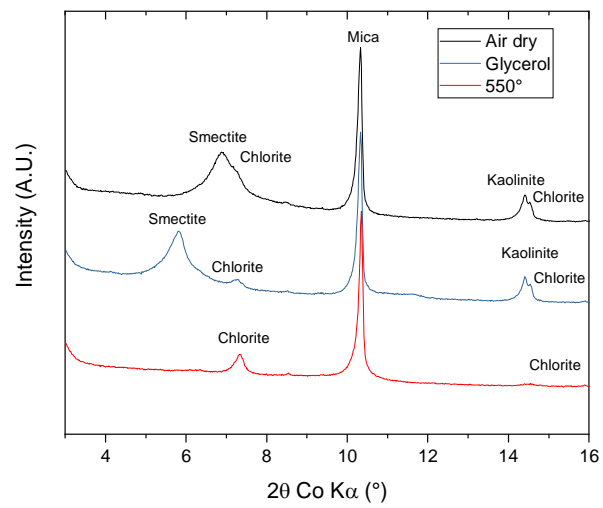

Figure 6. (a) Comparisons of $X$ ray diffraction patterns of the bulk and the clay fraction $(<2 \mu \mathrm{m})$ and (b) clay mineralogy on oriented air-dried, glycolated and heated of tailing sample BZN_1_13.25-14.75m_3T. Abbreviations: Sm: smectite, Chl: Chlorite, G: Gypsum, K: Kaolinite, M: Mica, Q: Quartz, Kf: K-felspar, Pl: Plagioclase, Fe ox: Fe oxide, Px: Pyroxene. 


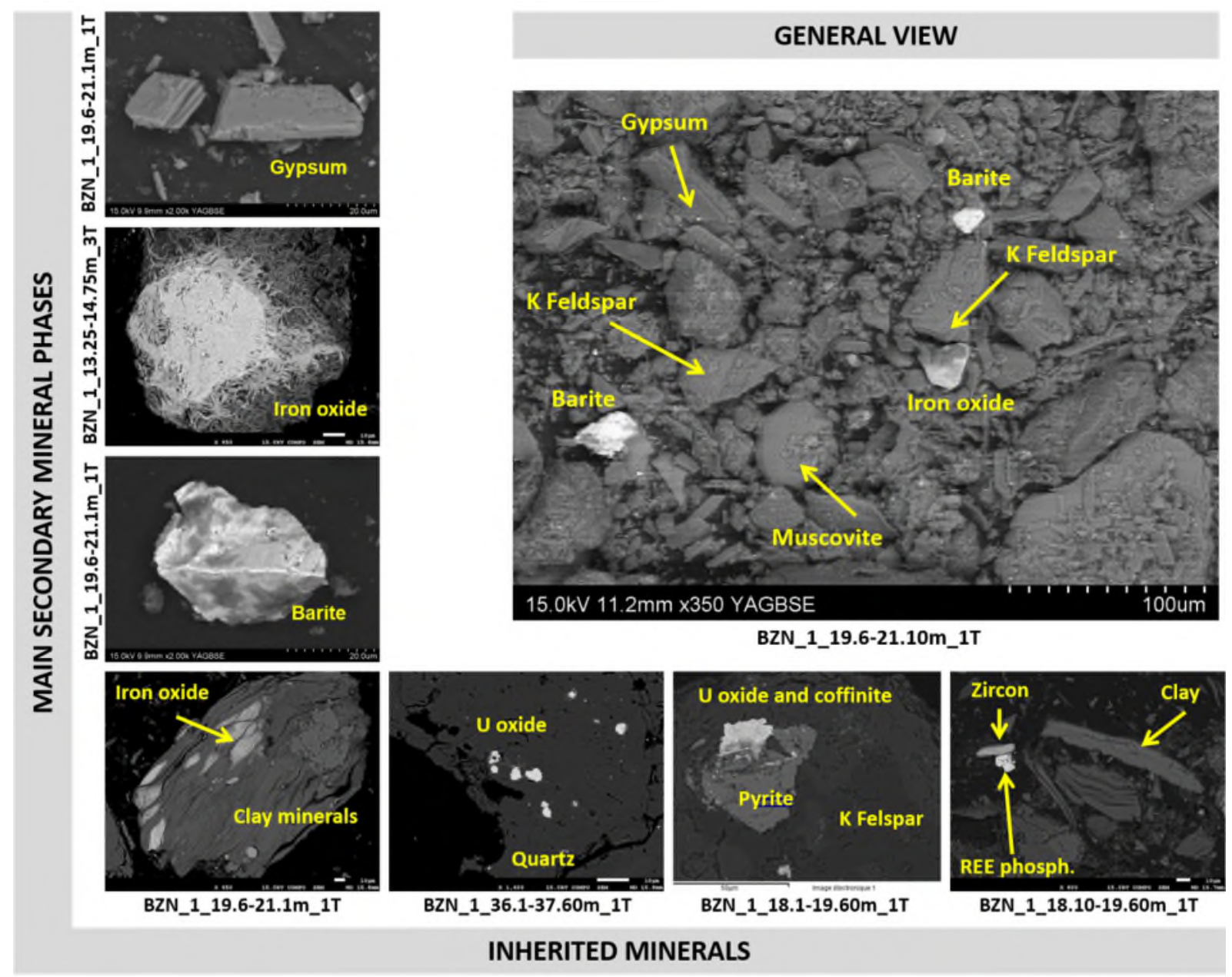

Figure 7. SEM images of Bellezane tailings. In the center, an overall view completed by details of inherited phases and secondary phases (inherited and/or neo-formed) on powder or thin sections. Phases were identified by SEM-EDX (EDX spectra not shown). 


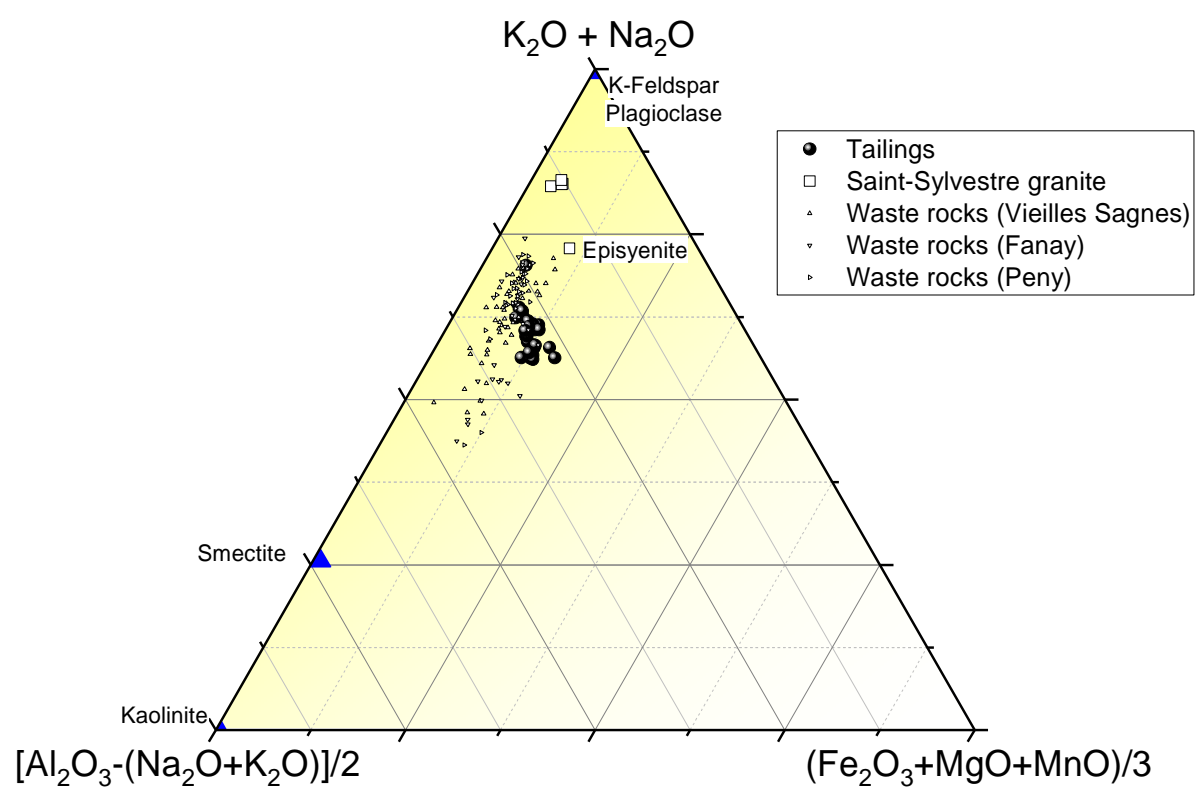

Figure 8. Ternary diagram $\left(\mathrm{K}_{2} \mathrm{O}+\mathrm{Na}_{2} \mathrm{O}\right)-\left(\left[\mathrm{Al}_{2} \mathrm{O}_{3}-\left(\mathrm{Na}_{2} \mathrm{O}+\mathrm{K}_{2} \mathrm{O}\right)\right] / 2\right)-\left(\left[\mathrm{Fe}_{2} \mathrm{O}_{3}+\mathrm{MgO}+\mathrm{MnO}\right] / 3\right)$ showing the weathering of feldspars to clay minerals in BZN samples. Additional data from Boekhout et al. (2015) and Kanzari et al. (2017) for waste rocks are also plotted. 


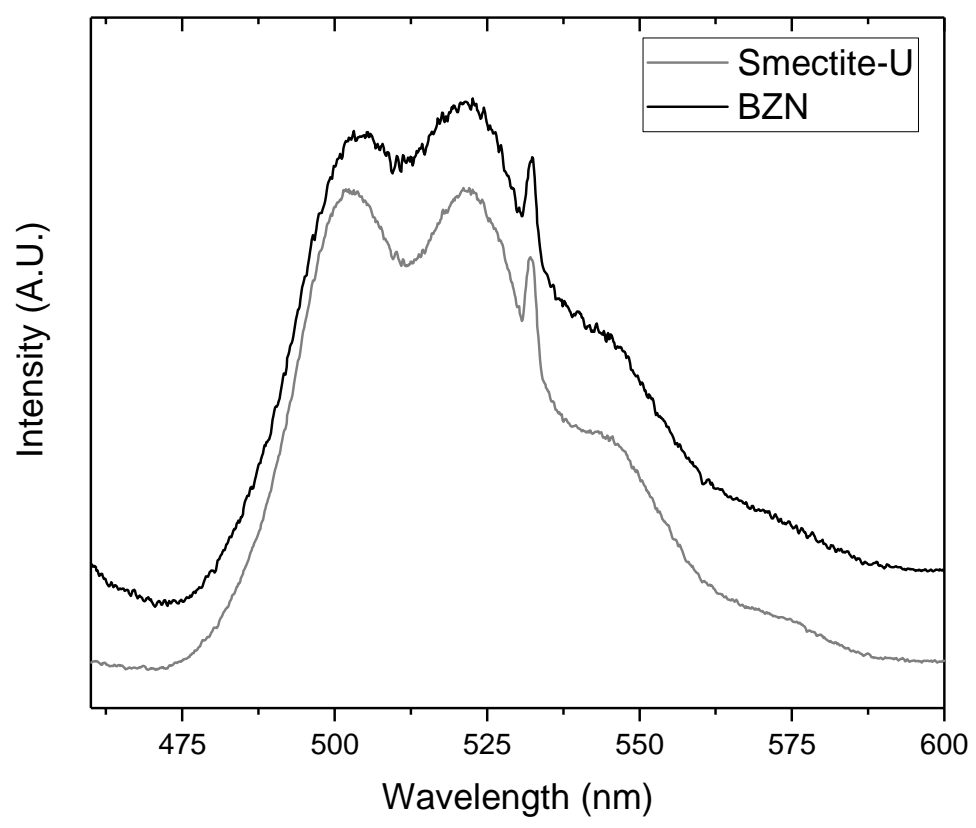

Figure 9. TRLFS spectra of a BZN sample (BZN_1_13.25-14.75m_2T) and a smectite doped with sorbed uranium. 


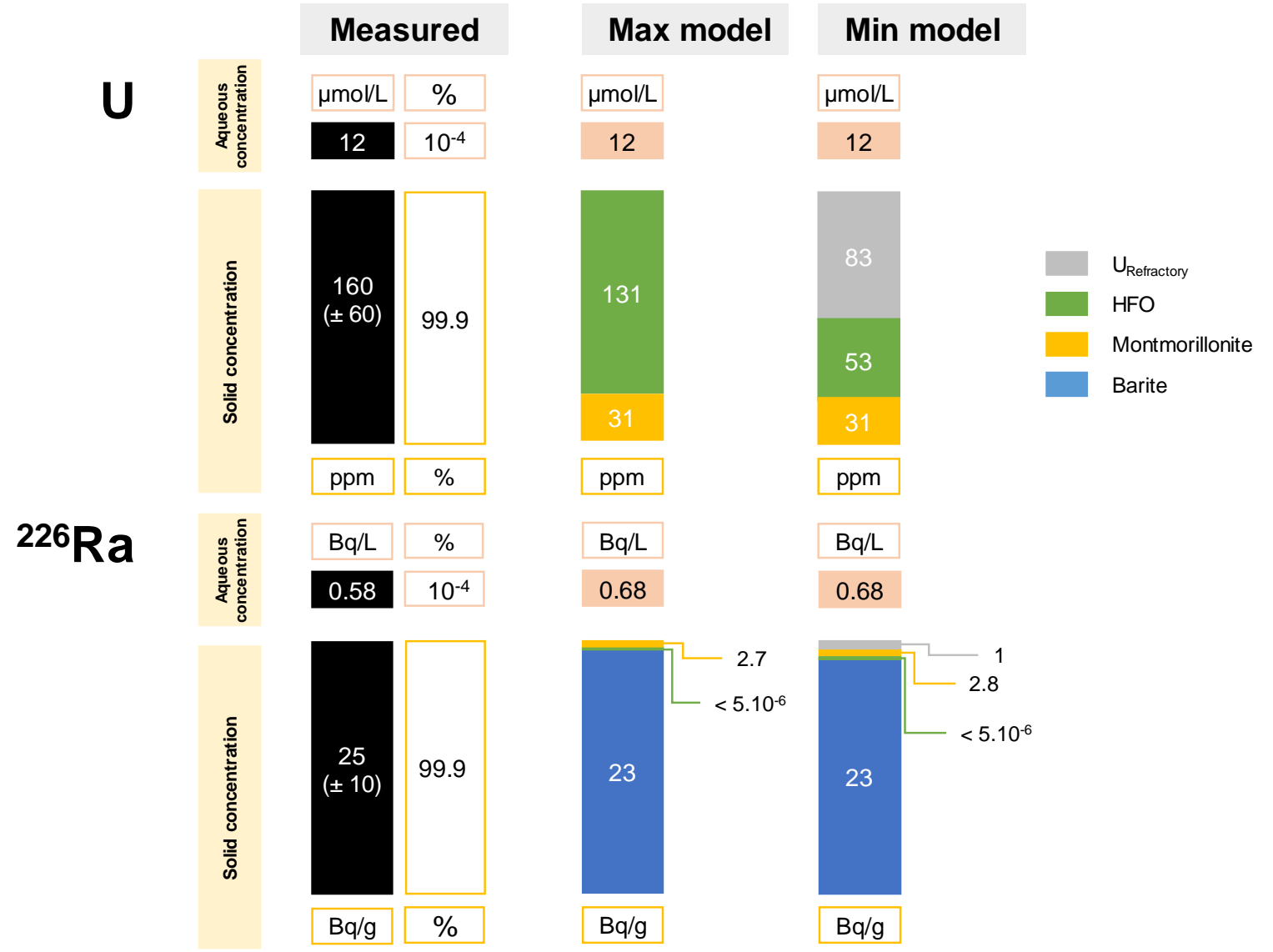

Figure 10. Distribution of $\mathrm{U}$ and ${ }^{226} \mathrm{Ra}$ within the mill tailings and according to the Min and Max models developed in this study. The Min model considers that a fraction of the radioelement is trapped in phases inherited from the ore that are considered non-reactive. The Max model considers all the radioelements as reactive. 

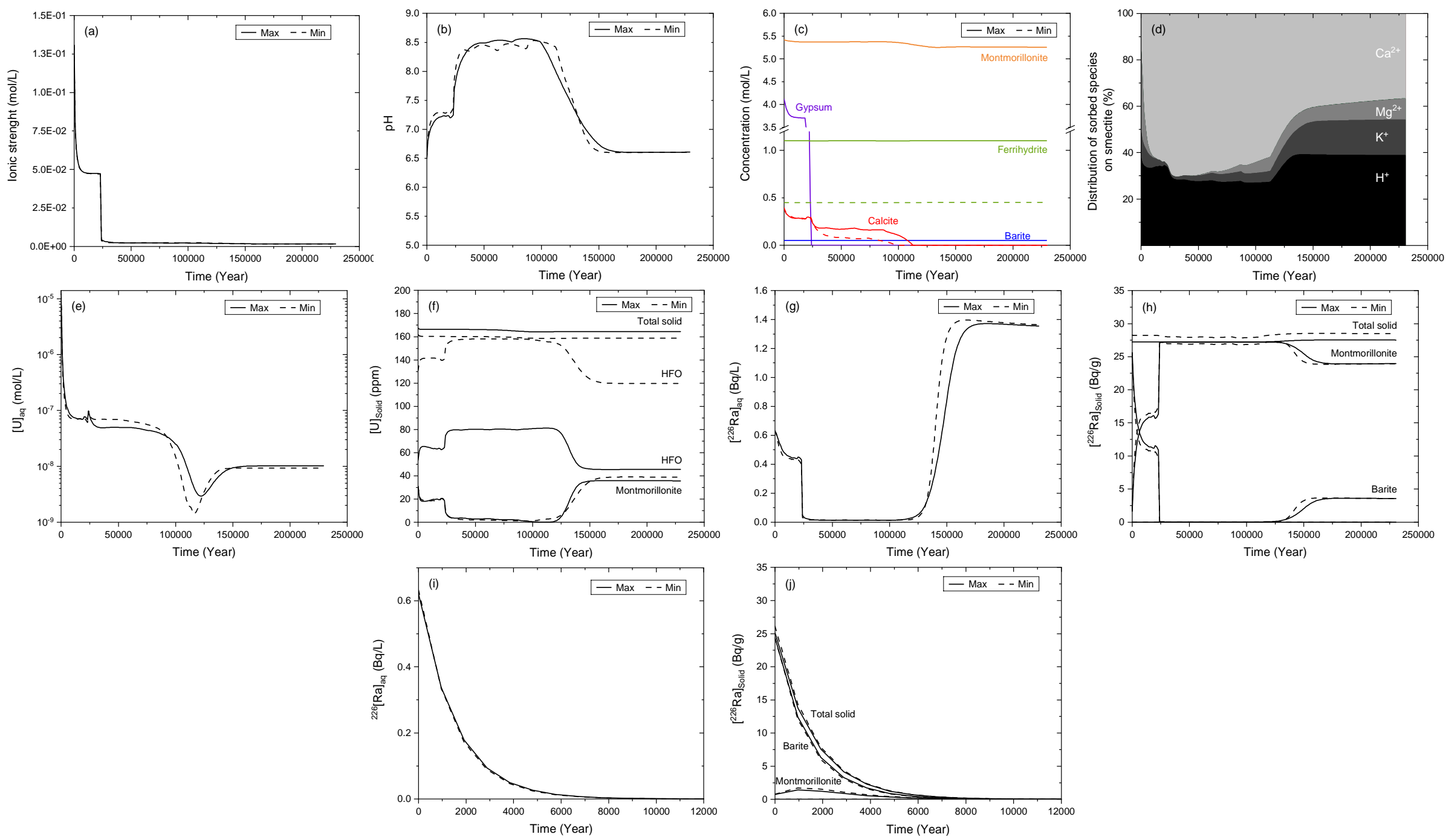

Figure 11. Long term reactivity model for the evolution of (a) ionic strength, (b) $\mathrm{pH}$, (c) principal minerals, (d) cationic populations sorbed to the surface of clay minerals (Min model; sorbed Na was too low to appear in the scale), (e) aqueous $\mathrm{U}$, (f) $\mathrm{U}$ in solid, (g) aqueous ${ }^{226} \mathrm{Ra}$ without taking into consideration radioactive decay, (h) ${ }^{226} \mathrm{Ra}$ in solid without taking into consideration radioactive decay, (i) aqueous ${ }^{226} \mathrm{Ra}$ taking into consideration radioactive decay, and (j) ${ }^{226} \mathrm{Ra}$ in solid taking into consideration radioactive decay (a time scale change was done on $7.5 \mathrm{x}{ }^{226} \mathrm{Ra}$ radioactive decay). The Max model does not take into account the presence of refractory phases. For the Min model, the U and ${ }^{226} \mathrm{Ra}$ contents of the refractory phases have been added to the total solid part on graphs (f), (h) and (j). 
Table 1. Chemical composition of the ES85 porewater solution (measured and modeled) and the granitic water (ES60; from Ledoux and Schmitt, 2010) percolating in the tailings column. All the concentrations are given in mol/L, except ${ }^{226} \mathrm{Ra}$

\begin{tabular}{|c|c|c|c|}
\hline & $\begin{array}{c}\text { ES85- } \\
\text { Measured }\end{array}$ & $\begin{array}{c}\text { ES85- } \\
\text { Modeled }\end{array}$ & ES60 \\
\hline $\mathrm{pH}$ & 6.35 & 6.49 & 6.31 \\
\hline Eh (mV/SHE) & 138 & 185 & 319 \\
\hline $\mathrm{T}\left({ }^{\circ} \mathrm{C}\right)$ & 12 & 12 & 13.8 \\
\hline Ionic strength & 0.13 & 0.13 & $1.6910^{-3}$ \\
\hline \multicolumn{4}{|l|}{ Anions } \\
\hline$[\mathrm{Cl}]_{\text {tot }}$ & $8.5 \times 10^{-3}$ & $8.5 \times 10^{-3}$ & $1.8 \times 10^{-4}$ \\
\hline$[F]_{\text {tot }}$ & $7.8 \times 10^{-4}$ & $7.8 \times 10^{-4}$ & $7.4 \times 10^{-5}$ \\
\hline$\left[\mathrm{NO}_{3}\right]_{\text {tot }}$ & $1.2 \times 10^{-3}$ & $1.2 \times 10^{-3}$ & \\
\hline$\left[\mathrm{SO}_{4}\right]_{\text {tot }}$ & $4.3 \times 10^{-2}$ & $4.3 \times 10^{-2}$ & $2.3 \times 10^{-4}$ \\
\hline$\left[\mathrm{PO}_{4}\right]_{\text {tot }}$ & $7.6 \times 10^{-8}$ & $7.6 \times 10^{-8}$ & $6.3 \times 10^{-7}$ \\
\hline$[S i]_{\text {tot }}$ & $1.5 \times 10^{-4}$ & $9.4 \times 10^{-5}$ & $2 \times 10^{-4}$ \\
\hline TIC & $2.5 \times 10^{-2}$ & $2.6 \times 10^{-2}$ & $6.6 \times 10^{-4}$ \\
\hline \multicolumn{4}{|l|}{ Cations } \\
\hline$[\mathrm{Na}]_{\text {tot }}$ & $8.9 \times 10^{-3}$ & $8.9 \times 10^{-3}$ & $2.5 \times 10^{-4}$ \\
\hline$[\mathrm{K}]_{\text {tot }}$ & $1.7 \times 10^{-3}$ & $1.6 \times 10^{-3}$ & $3.8 \times 10^{-5}$ \\
\hline$[\mathrm{Mg}]_{\text {tot }}$ & $3.3 \times 10^{-2}$ & $3.3 \times 10^{-2}$ & $1.4 \times 10^{-4}$ \\
\hline$[\mathrm{Ca}]_{\text {tot }}$ & $1.3 \times 10^{-2}$ & $1.5 \times 10^{-2}$ & $2.8 \times 10^{-4}$ \\
\hline$[\mathrm{Sr}]_{\text {tot }}$ & $3.8 \times 10^{-6}$ & $3.8 \times 10^{-6}$ & \\
\hline$[\mathrm{Ba}]_{\text {tot }}$ & $1.0 \times 10^{-7}$ & $3.8 \times 10^{-8}$ & $2.83 \times 10^{-7}$ \\
\hline \multicolumn{4}{|l|}{ Metals } \\
\hline$[A \mid]_{\text {tot }}$ & $7.0 \times 10^{-5}$ & $3.2 \times 10^{-5}$ & $6.9 \times 10^{-7}$ \\
\hline$[\mathrm{Mn}]_{\text {tot }}$ & $1.0 \times 10^{-3}$ & $1.0 \times 10^{-3}$ & \\
\hline$[\mathrm{Fe}]_{\text {tot }}$ & $7.9 \times 10^{-3}$ & $7.9 \times 10^{-3}$ & $1 \times 10^{-5}$ \\
\hline$\left[{ }^{226} \mathrm{Ra}\right]_{\mathrm{tot}}$ & 0.58 & 0.68 & 0.2 \\
\hline$[U]_{\text {tot }}$ & $1.2 \times 10^{-5}$ & $1.2 \times 10^{-5}$ & $1.7 \times 10^{-8}$ \\
\hline Elec. Bal. (\% err) & $6.24 \%$ & $6.06 \%$ & $6.83 \%$ \\
\hline
\end{tabular}




\title{
SUPPLEMENTARY INFORMATIONS: A MULTI-SCALAR STUDY OF THE LONG-TERM REACTIVITY OF URANIUM MILL TAILINGS (BELLEZANE, FRANCE)
}

\author{
M. BALLINI ${ }^{1}$, C. CHAUTARD ${ }^{1}$, J. NOS ${ }^{1}$, V. PHROMMAVANH ${ }^{1}$, C. BEAUCAIRE ${ }^{2}$, C. \\ BESANCON $^{1,3}$, A. BOIZARD ${ }^{4}$, M. CATHELINEAU ${ }^{4}$, C. PEIFFERT $^{4}$, T. VERCOUTER ${ }^{5}$, E. VORS 5 ,
} M. DESCOSTES ${ }^{1, *}$

${ }^{1}$ : ORANO Mining, R\&D Dpt, 125 avenue de Paris, F-92330 Châtillon, France

2 : DEN, Service d'Etude du Comportement des Radionucléides (SECR), CEA, Université Paris-Saclay, F-91191 Gif-sur-Yvette, France

3: Institut de Minéralogie de Physique des Matériaux et de Cosmochimie (IMPMC), Sorbonne Université, F-75005 Paris, France.

${ }^{4}$ : Université de Lorraine, CNRS, CREGU, GeoRessources, F-54000 Nancy, France

${ }^{5}$ : DEN, Service d'Etudes Analytiques et de Réactivité des Surfaces (SEARS), CEA, Université ParisSaclay, F-91191 Gif sur Yvette, France

* : corresponding author, michael.descostes@ orano.group 


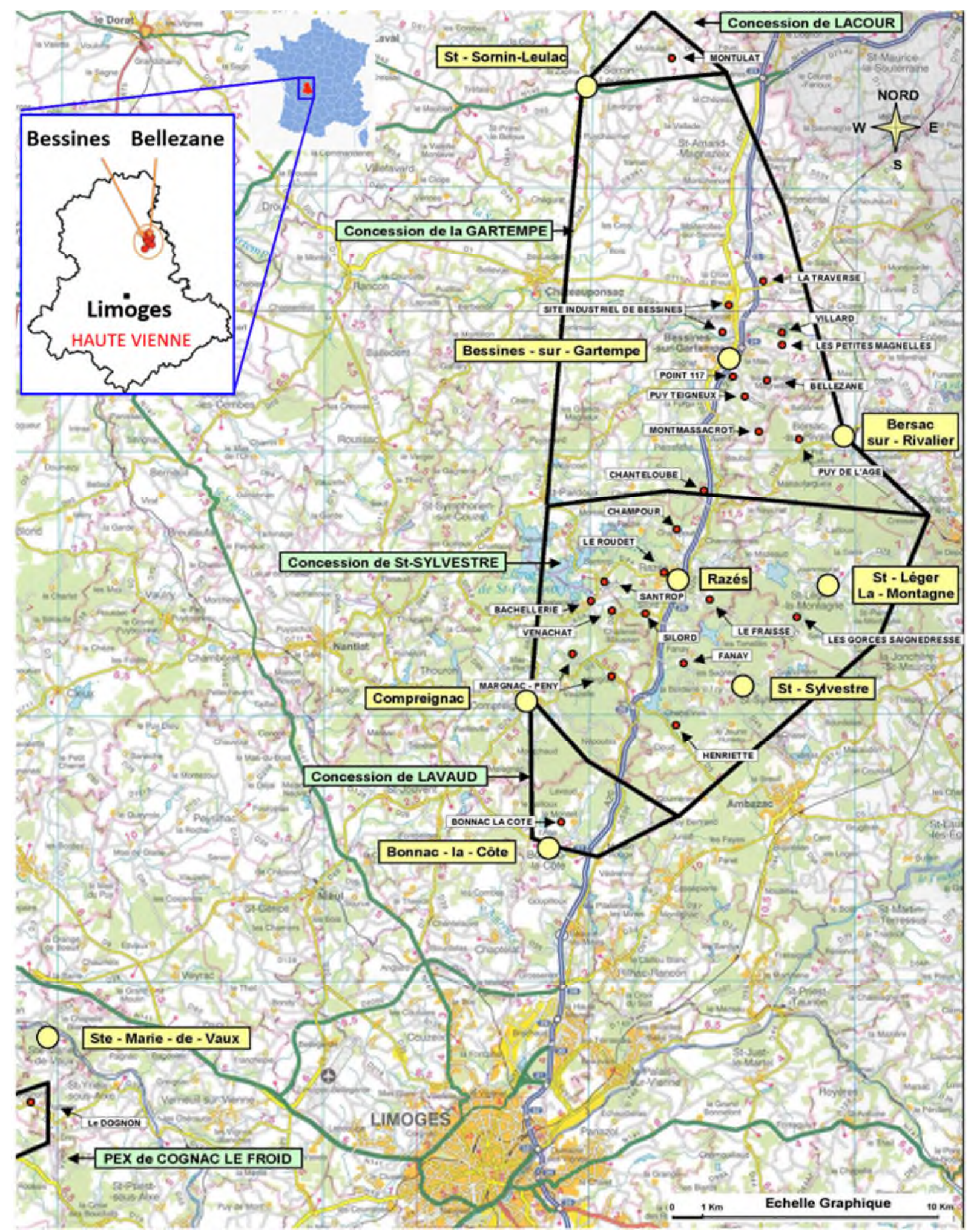

Figure SI-1. Location of the La Crouzille mining division, its mining operations, and the Bellezane Tailings Management Facility (GEP, 2010). 


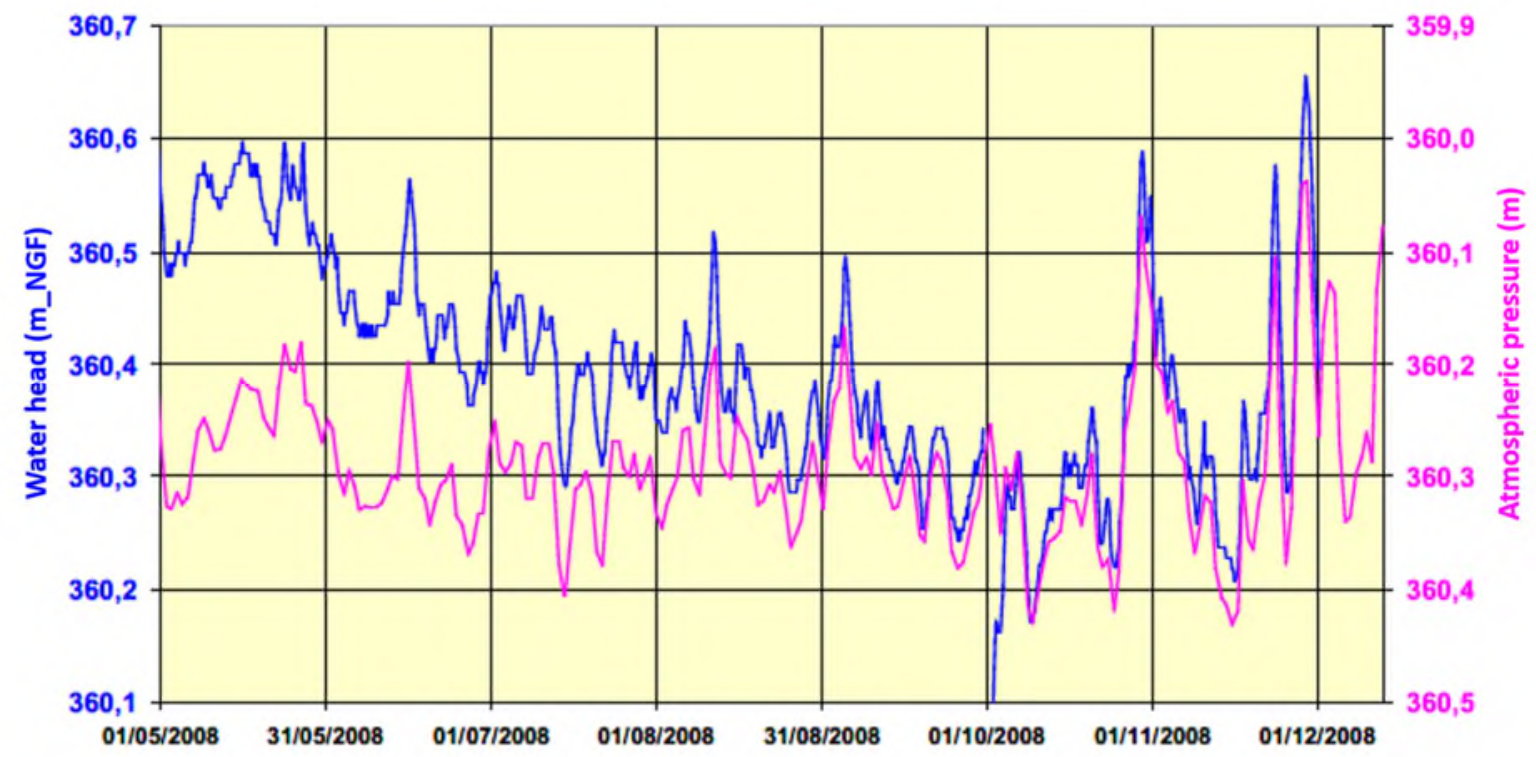

Figure SI-2. Correlation between the piezometric height measured at ES85 and atmospheric pressure (Ledoux and Schmitt, 2010). 


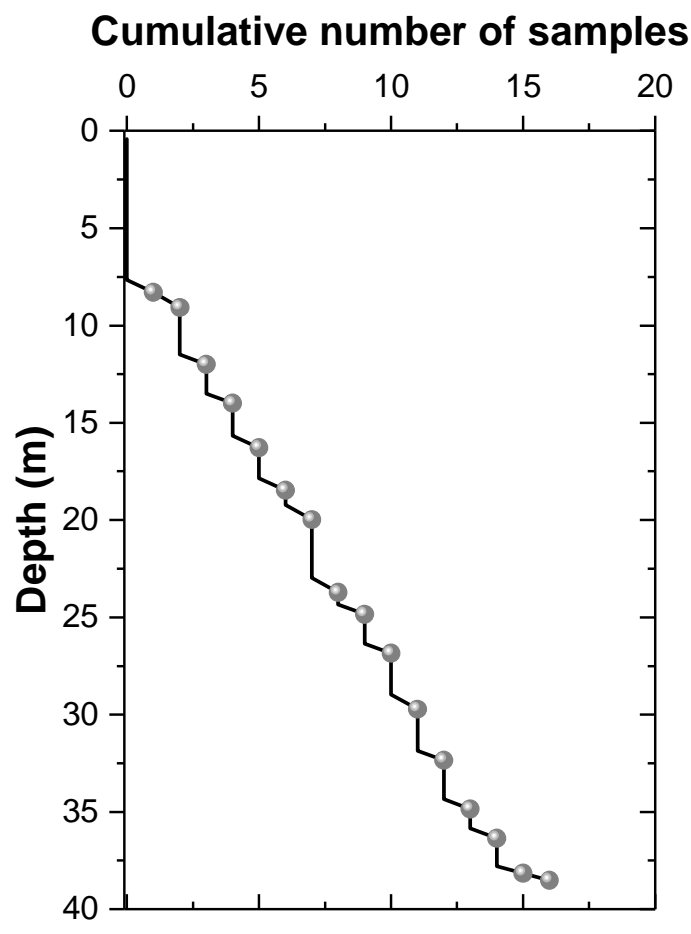

Figure SI-3. Cumulative number of samples as a function of depth. The grey dots represent the samples that have undergone full characterization. 


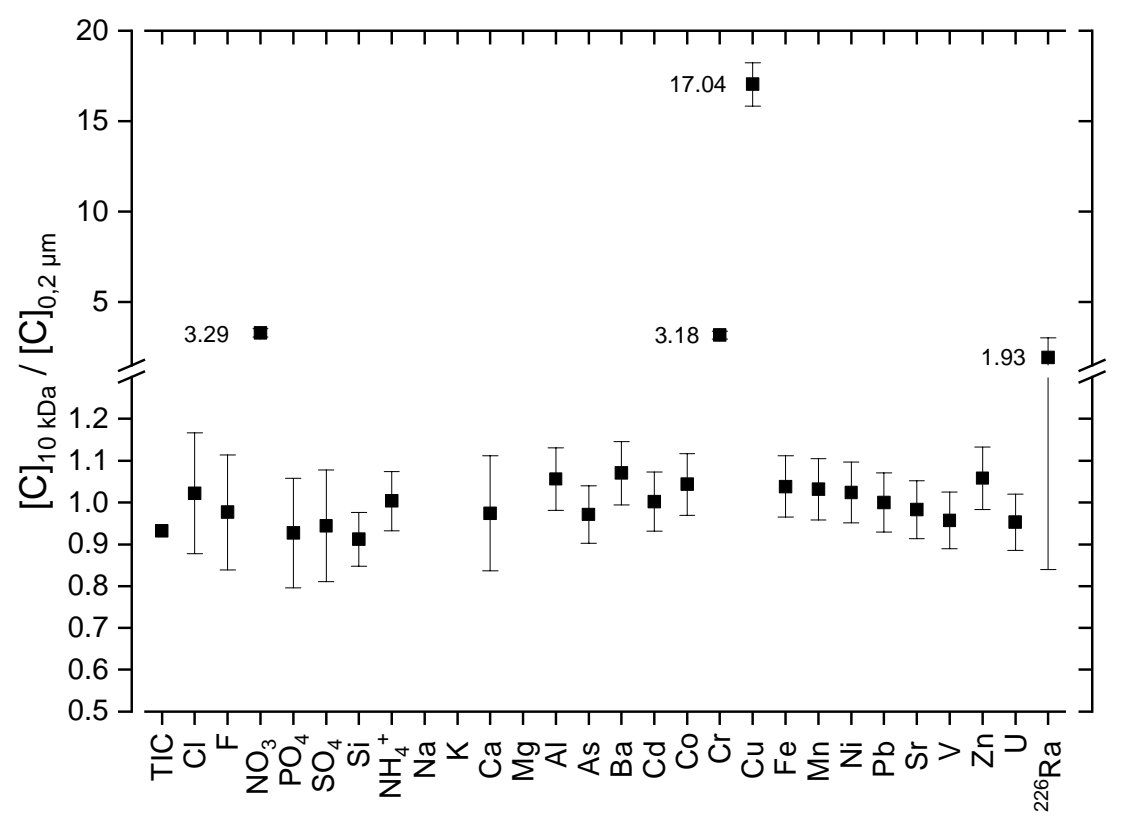

Figure SI-4. Ratios of concentrations measured in the porewater fraction filtered at $10 \mathrm{kDa}$ and $0.2 \mu \mathrm{m}$, sampled in piezometer ES85. 

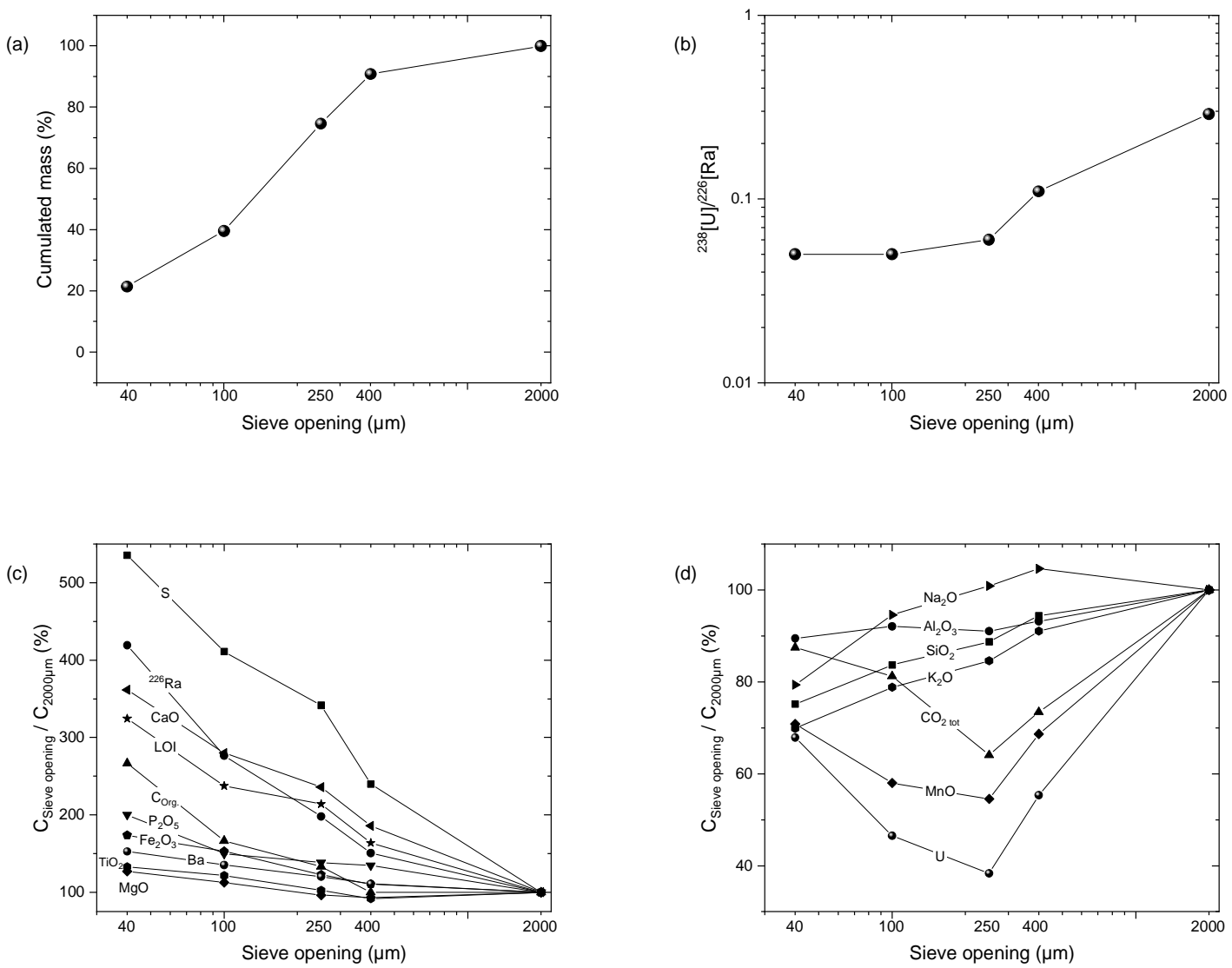

Figure SI-5. Particle size distribution (a), $\left[{ }^{238} \mathrm{U}\right] /\left[{ }^{226} \mathrm{Ra}\right]$ mass activity ratio (b), major (c) and trace (d) element concentrations in each of the particle size fractions of sample BZN_1_13.25-14.75m_2T. The concentrations of major and trace elements in each particle size fraction are normalized with those measured in the $2000 \mu \mathrm{m}$ fraction. 


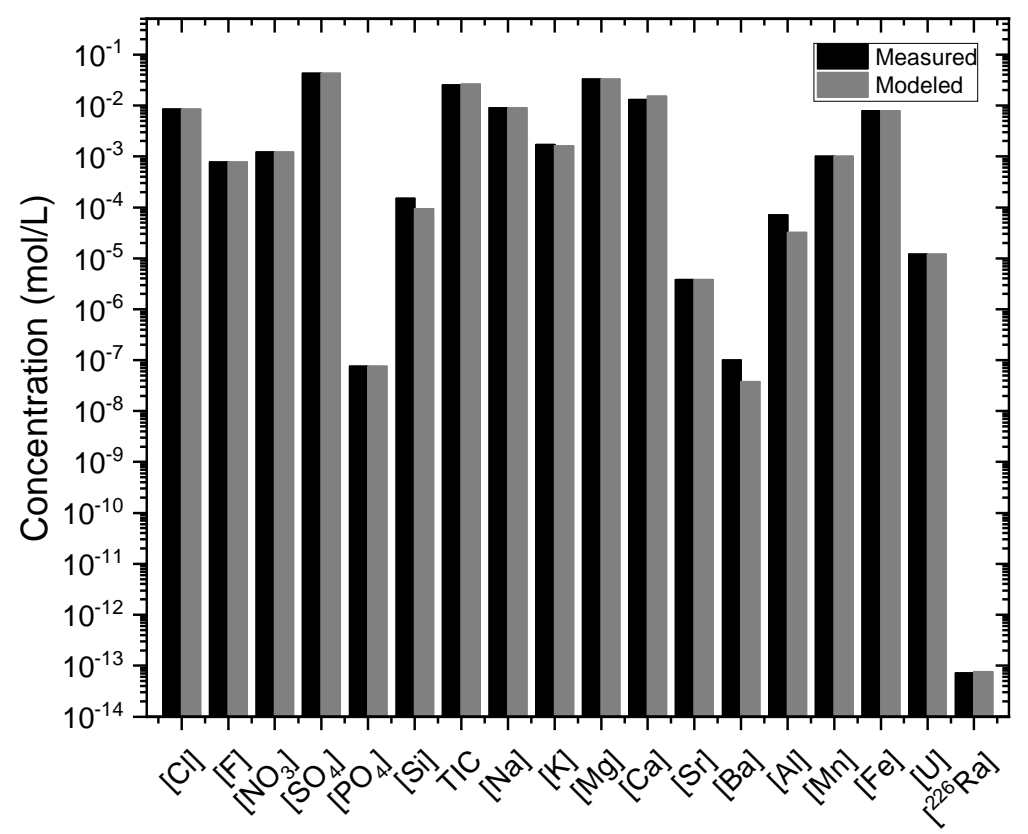

Figure SI-6. Comparison between measured and modeled ES85 porewater concentrations. 

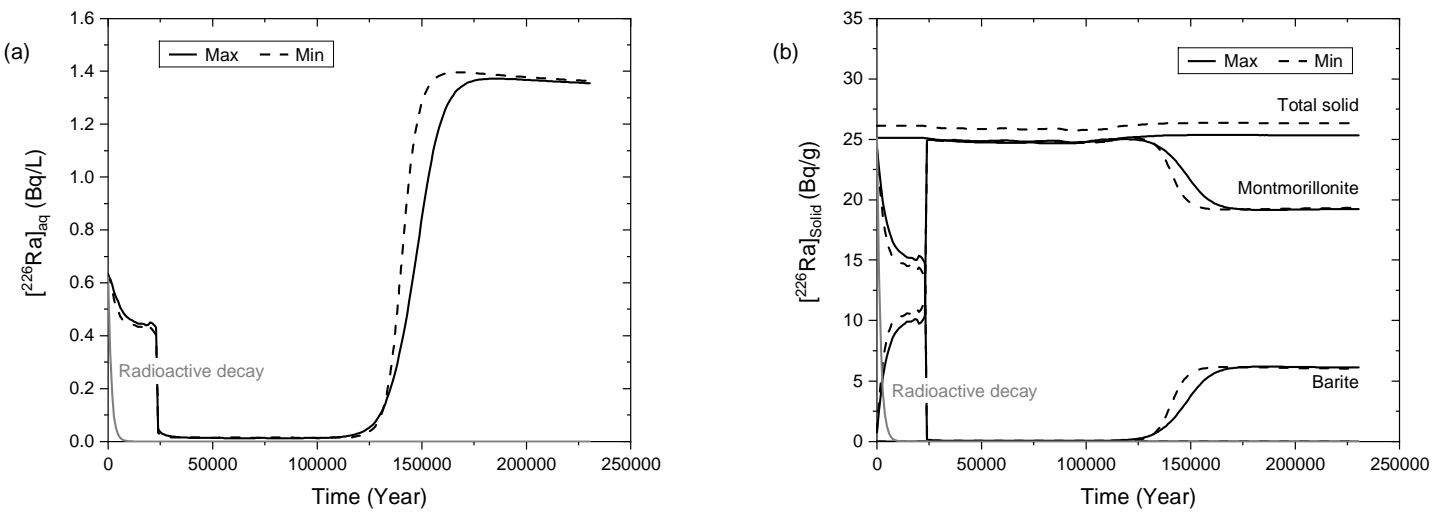

Figure SI-7. Evolution of aqueous ${ }^{226} \mathrm{Ra}$ without taking into account the radioactive decay (a), and ${ }^{226} \mathrm{Ra}$ in the solid without taking into account the radioactive decay (b) and considering a percolation water without ${ }^{226} \mathrm{Ra}$. Values with radioactive decay are shown in light grey on both figures. 
TableaSI-1. Summary of the characterization analyses carried out for all the samples studied.

\begin{tabular}{|l|c|c|c|c|c|c|}
\hline \multicolumn{1}{|c|}{ Sample name } & $\begin{array}{c}\text { Mean depth } \\
(m)\end{array}$ & Chemistry & $\begin{array}{c}\text { Radiological } \\
\text { characterization }\end{array}$ & $\begin{array}{c}\text { Mineralogical } \\
\text { characterization }\end{array}$ & $\begin{array}{c}\text { Particle-size } \\
\text { distribution }\end{array}$ & TRLFS \\
\hline BZN 1_Carotte 1 & 1.30 & & $\mathrm{X}$ & & & \\
\hline BZN 1_Carotte 3 & 3.85 & & $\mathrm{X}$ & & & \\
\hline BZN 1_Carotte 5 & 7.15 & & $\mathrm{X}$ & & & \\
\hline BZN_1_7.90-10.25m_1T & 8.30 & $\mathrm{X}$ & $\mathrm{X}$ & $\mathrm{X}$ & & $\mathrm{X}$ \\
\hline BZN_1_7.90-10.25m_2T & 9.10 & $\mathrm{X}$ & $\mathrm{X}$ & $\mathrm{X}$ & & \\
\hline BZN_1_11.75-13.25m_1T & 12.00 & $\mathrm{X}$ & $\mathrm{X}$ & $\mathrm{X}$ & & \\
\hline BZN_1_13.25-14.75m_1T & 13.50 & $\mathrm{X}$ & & $\mathrm{X}$ & & \\
\hline BZN_1_13.25-14.75m_2T & 14.00 & $\mathrm{X}$ & $\mathrm{X}$ & $\mathrm{X}$ & & $\mathrm{X}$ \\
\hline BZN_1_13.25-14.75m_3T & 14.50 & $\mathrm{X}$ & & $\mathrm{X}$ & & \\
\hline BZN_1_14.75-16.60m_3T & 16.30 & $\mathrm{X}$ & $\mathrm{X}$ & $\mathrm{X}$ & & \\
\hline BZN_1_18.10-19.60m_1T & 18.50 & $\mathrm{X}$ & $\mathrm{X}$ & $\mathrm{X}$ & & \\
\hline BZN_1_19.60-21.10m_1T & 20.00 & $\mathrm{X}$ & $\mathrm{X}$ & $\mathrm{X}$ & & \\
\hline BZN_1_22.60-24.10m_2T & 23.70 & $\mathrm{X}$ & $\mathrm{X}$ & $\mathrm{X}$ & & \\
\hline BZN_1_24.10-25.60m_2T & 24.90 & $\mathrm{X}$ & $\mathrm{X}$ & $\mathrm{X}$ & & \\
\hline BZN_1_25.60-27.10m_3T & 26.90 & $\mathrm{X}$ & $\mathrm{X}$ & $\mathrm{X}$ & & \\
\hline BZN_1_28.60-30.10m_2T & 29.70 & $\mathrm{X}$ & $\mathrm{X}$ & $\mathrm{X}$ & & \\
\hline BZN_1_31.60-33.10m_2T & 32.40 & $\mathrm{X}$ & $\mathrm{X}$ & $\mathrm{X}$ & & \\
\hline BZN_1_34.60-36.10m_1T & 34.90 & $\mathrm{X}$ & $\mathrm{X}$ & $\mathrm{X}$ & & \\
\hline BZN_1_36.10-37.60m_1T & 36.40 & $\mathrm{X}$ & $\mathrm{X}$ & $\mathrm{X}$ & & \\
\hline BZN_1_37.60-38.70m_2T & 38.20 & $\mathrm{X}$ & $\mathrm{X}$ & $\mathrm{X}$ & & \\
\hline BZN_1_37.60-38.70m_3T & 38.50 & $\mathrm{X}$ & $\mathrm{X}$ & $\mathrm{X}$ & & \\
\hline
\end{tabular}


Table SI-2. Sorption constants of $\mathrm{U},{ }^{226} \mathrm{Ra}$ and $\mathrm{CO}_{3}{ }^{2-}$ on ferrihydrite added to the PHREEQC database (_w and _s stands for weak and strong binding sites respectively).

\begin{tabular}{|c|c|c|c|}
\hline & & Lg k & Reference \\
\hline \multirow{2}{*}{${ }^{226} \mathrm{Ra}$} & $\mathrm{HFO} \_\mathrm{sOH}+\mathrm{Ra}^{2+}=\mathrm{HFO} \_\mathrm{sOHRa}{ }^{2+}$ & 6.66 & \multirow{2}{*}{ Sajih et al. 2014} \\
\hline & $\mathrm{HFO} \_\mathrm{wOH}+\mathrm{Ra}^{2+}=\mathrm{HFO} \_\mathrm{wORa}^{+}+\mathrm{H}^{+}$ & -5.67 & \\
\hline \multirow{5}{*}{$\mathbf{U}$} & $\mathrm{HFO} \_\mathrm{sOH}+\mathrm{UO}_{2}^{2+}=\mathrm{HFO} \_\mathrm{sOUO} 2^{+}+\mathrm{H}^{+}$ & 3.73 & \multirow{5}{*}{ Mahoney et al. 2019} \\
\hline & $\mathrm{HFO} \_\mathrm{wOH}+\mathrm{UO}_{2}^{2+}=\mathrm{HFO} \_\mathrm{wOUO}_{2}{ }^{+}+\mathrm{H}^{+}$ & 2.53 & \\
\hline & $\mathrm{HFO} \_\mathrm{wOH}+\mathrm{UO}_{2}{ }^{+2}+\mathrm{CO}_{3}{ }^{2-}=\mathrm{HFO} \_\mathrm{wOUO}_{2} \mathrm{CO}_{3}{ }^{-}+\mathrm{H}^{+}$ & 9.03 & \\
\hline & $\mathrm{HFO} \_\mathrm{wOH}+\mathrm{UO}_{2}{ }^{2+}+2 \mathrm{CO}_{3}{ }^{2-}=\mathrm{HFO} \_\mathrm{wOUO}_{2}\left(\mathrm{CO}_{3}\right)_{2^{3-}}+\mathrm{H}^{+}$ & 15.28 & \\
\hline & $\mathrm{HFO} \_\mathrm{wOH}+\mathrm{UO}_{2}^{2+}+\mathrm{H}_{2} \mathrm{O}=\mathrm{HFO} \_\mathrm{wOUO}_{2} \mathrm{OH}+2 \mathrm{H}^{+}$ & -5.11 & \\
\hline \multirow{2}{*}{$\mathrm{CO}_{3}{ }^{2-}$} & $\mathrm{HFO} \_w O H+\mathrm{CO}_{3}^{2-}+\mathrm{H}^{+}=\mathrm{HFO} \_\mathrm{wOCO}_{2}^{-}+\mathrm{H}_{2} \mathrm{O}$ & 12.78 & \multirow{2}{*}{ Mahoney et al. 2019} \\
\hline & $\mathrm{HFO} \_\mathrm{wOH}+\mathrm{CO}_{3}{ }^{2-}+2 \mathrm{H}^{+}=\mathrm{HFO} \_w O \mathrm{CO}_{2} \mathrm{H}+\mathrm{H}_{2} \mathrm{O}$ & 20.37 & \\
\hline
\end{tabular}


Table SI-3. Site concentration and selectivity coefficients of cation exchange reactions for montmorillonite added to the PHREEQC database (Gaines-Thomas convention) (Reinoso-Maset et al., 2012a and 2012b).

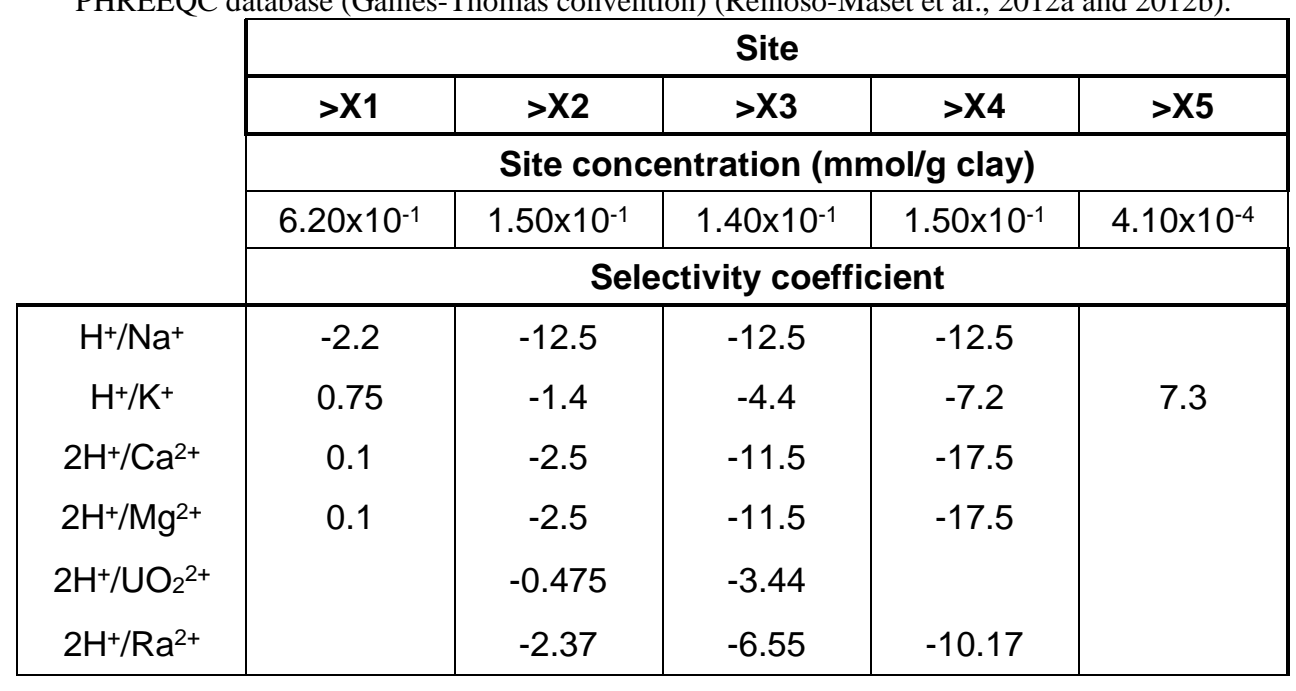


Table SI-4. Mean $\left(\mathrm{C}_{\text {mean }}\right)$, minimum $\left(\mathrm{C}_{\min }\right)$ and maximum $\left(\mathrm{C}_{\max }\right)$ elemental levels measured in $\mathrm{BZN}$ samples. Mean values are accompanied by the standard deviations. $\mathrm{Corg}_{\text {ond }}$ LOI denote organic $\mathrm{C}$ content and loss on ignition respectively.

\begin{tabular}{|c|c|c|c|}
\hline & $\mathrm{C}_{\text {mean }}$ & $\mathbf{C}_{\min }$ & $\mathrm{C}_{\max }$ \\
\hline & \multicolumn{3}{|c|}{ Major elements(\%) } \\
\hline $\mathrm{SiO}_{2}$ & $61.9 \pm 4.4$ & 55.4 & 73.2 \\
\hline $\mathrm{Al}_{2} \mathrm{O}_{3}$ & $13.1 \pm 0.8$ & 11.2 & 14.5 \\
\hline $\mathrm{K}_{2} \mathrm{O}$ & $5.04 \pm 0.27$ & 4.61 & 5.57 \\
\hline $\mathrm{CaO}$ & $3.48 \pm 0.93$ & 1.07 & 4.77 \\
\hline $\mathrm{Fe}_{2} \mathrm{O}_{3}$ & $2.94 \pm 0.61$ & 1.50 & 3.76 \\
\hline $\mathrm{Na}_{2} \mathrm{O}$ & $1.68 \pm 0.29$ & 1.26 & 2.61 \\
\hline$S$ total & $1.85 \pm 0.45$ & 0.40 & 2.53 \\
\hline $\mathrm{MgO}$ & $0.77 \pm 0.26$ & 0.32 & 1.19 \\
\hline $\mathrm{P}_{2} \mathrm{O}_{5}$ & $0.33 \pm 0.05$ & 0.24 & 0.42 \\
\hline $\mathrm{TiO}_{2}$ & $0.27 \pm 0.07$ & 0.16 & 0.46 \\
\hline MnO & $0.05 \pm 0.02$ & 0.03 & 0.09 \\
\hline $\mathrm{CO}_{2}$ total & $0.52 \pm 0.25$ & 0.24 & 1.23 \\
\hline Corg $_{\text {or }}$ & $0.08 \pm 0.04$ & 0.03 & 0.20 \\
\hline \multirow[t]{2}{*}{ LOI } & $9.69 \pm 2.39$ & 2.56 & 14.02 \\
\hline & \multicolumn{3}{|c|}{ Traces (ppm) } \\
\hline $\mathrm{Ba}$ & $839 \pm 609$ & 294.9 & 2502 \\
\hline \multirow[t]{2}{*}{ U } & $169 \pm 61$ & 77.7 & 292.4 \\
\hline & \multicolumn{3}{|c|}{${ }^{226} \mathrm{Ra}(\mathrm{Bq} / \mathrm{g})$} \\
\hline${ }^{226} \mathrm{Ra}$ & $23 \pm 15$ & 0.3 & 44.5 \\
\hline
\end{tabular}


Table SI-5. Trace-level element concentrations measured in mill tailings samples (D. L. stands for detection limit).

\begin{tabular}{|c|c|c|c|c|c|c|c|c|c|c|c|c|}
\hline & $\begin{array}{l}\text { BZN / } \\
7.9- \\
10.25 \mathrm{~m} / \\
1 \mathrm{~T} \mathrm{~A}\end{array}$ & $\begin{array}{c}\text { BZN / } \\
7.9- \\
10.25 \mathrm{~m} / \\
1 \mathrm{~T} /\end{array}$ & $\begin{array}{c}\text { BZN / } \\
7.9- \\
10.25 \mathrm{~m} / \\
2 \mathrm{~T}\end{array}$ & $\begin{array}{c}\text { BZN / } \\
11.75- \\
13.26 \mathrm{~m} / \\
1 \mathrm{~T}\end{array}$ & $\begin{array}{c}\text { BZN / } \\
13.26- \\
14.75 \mathrm{~m} / \\
1 \mathrm{~T}\end{array}$ & $\begin{array}{l}\text { BZN / } \\
13.26- \\
14.75 \mathrm{~m} / \\
\text { 2T A }\end{array}$ & $\begin{array}{c}\text { BZN / } \\
13.26- \\
14.75 \mathrm{~m} / \\
2 \mathrm{~T} \mathrm{~B}\end{array}$ & $\begin{array}{c}\text { BZN / } \\
13.26- \\
14.75 \mathrm{~m} / \\
3 \mathrm{~T}\end{array}$ & $\begin{array}{c}\text { BZN / } \\
14.75- \\
16.60 \mathrm{~m} / \\
3 \mathrm{~T}\end{array}$ & $\begin{array}{c}\text { BZN / } \\
18.10- \\
19.60 \mathrm{~m} / \\
1 \mathrm{~T}\end{array}$ & $\begin{array}{c}\mathrm{BZN} / \\
19.60- \\
21.10 \mathrm{~m} / \\
1 \mathrm{~T}\end{array}$ & $\begin{array}{l}\text { BZN / } \\
22.60- \\
24.10 \mathrm{~m} / \\
2 \mathrm{~T}\end{array}$ \\
\hline As & 42.32 & 143.50 & 146.60 & 146.40 & 146.00 & 176.70 & 172.80 & 91.26 & 147.20 & 156.30 & 173.30 & 78.71 \\
\hline $\mathrm{Ba}$ & 294.90 & 530.90 & 848.70 & 1026.00 & 508.20 & 539.00 & 1062.00 & 987.10 & 2463.00 & 389.20 & 961.50 & 399.70 \\
\hline $\mathrm{Be}$ & 16.53 & 4.65 & 19.20 & 22.38 & 20.40 & 2.71 & 22.28 & 17.50 & 18.13 & 18.21 & 22.42 & 19.07 \\
\hline $\mathrm{Bi}$ & 3.17 & 10.60 & 7.85 & 3.15 & 3.49 & 40 & 97 & .52 & $.0<$ & 9.45 & .06 & 5.74 \\
\hline $\mathrm{Cd}$ & 0.94 & & 34 & 0.37 & 25 & 68 & 29 & 24 & 26 & .78 & 29 & .23 \\
\hline $\mathrm{Ce}$ & 39.62 & 54.58 & 57.86 & 77.08 & 63.74 & 56.87 & 81.00 & 77.99 & 90.90 & 43.61 & 67.72 & 49.30 \\
\hline Co & 5.84 & 10.77 & 10.82 & 5.77 & 3.38 & 4.53 & 32 & 6.86 & .60 & 69 & .03 & 4.88 \\
\hline $\mathrm{Cr}$ & 21.04 & 23. & 19.63 & 37 & 17.84 & 18.38 & 41.28 & 55.17 & & & 35 & 0.02 \\
\hline Cs & 25.58 & 31.99 & 28.47 & 31.73 & 37.69 & 37.82 & 31.92 & 30.84 & 29.20 & 21.27 & 34.09 & 28.34 \\
\hline $\mathrm{Cu}$ & 169.70 & 238.10 & 221.80 & 19.34 & 22.13 & 51.40 & 18.14 & 24.62 & 45.83 & 335.60 & 19.50 & 51.77 \\
\hline Dy & 1.68 & 2.86 & 2.97 & 3.06 & 2.78 & 2.99 & 3.19 & 3.31 & $c_{1}$ & 2.8 & 2.96 & 2.20 \\
\hline $\mathrm{Er}$ & 0.61 & 1.02 & 1.02 & 1.09 & 0.98 & 1.15 & 1 & 1.22 & .0 & 0.96 & 06 & .77 \\
\hline $\mathrm{Eu}$ & 0.45 & 0.83 & 7 & & 0.66 & 0.69 & 0 & .06 & 1 & 0 & 90 & .49 \\
\hline $\mathrm{Ga}$ & 21.81 & 25.21 & 26.10 & 27.63 & 27.76 & 28.02 & 28.21 & 24.07 & 22.32 & 21.46 & 25.90 & 24.94 \\
\hline Gd & 2.65 & 4.63 & 4.84 & 5.29 & 4.62 & 4.74 & 5.32 & .27 & 6.34 & 4.29 & 4.89 & 3.48 \\
\hline $\mathrm{Ge}$ & 1.72 & 2.75 & & & 0 & 92 & 93 & .28 & 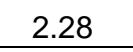 & 1 & 81 & .01 \\
\hline $\mathrm{Hf}$ & 2.30 & 3.19 & 3.36 & 4.33 & 3.49 & 3.37 & 4.52 & 4.88 & 5.8 & 2.58 & 3.97 & 2.85 \\
\hline Ho & 0.25 & 0.43 & 0.44 & 0.46 & 0.41 & 0.48 & 48 & .50 & 0.7 & 0. & 45 & 0.33 \\
\hline In & 0.09 & 0.15 & & IL & 12 & 0.13 & 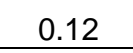 & 11 & 0.1 & 0.11 & 13 & 0.14 \\
\hline La & 18.79 & 26.00 & 27.05 & 36.83 & 30.40 & 27.30 & 40.28 & 39.33 & 51.29 & 20.26 & 33.22 & 22.72 \\
\hline Lu & 0.08 & & & & 0 & 13 & & 14 & 0 & 1. & 13 & .09 \\
\hline Mo & 0.65 & 0 & & & 0.87 & 0 & & 0 & & & 3 & 83 \\
\hline $\mathrm{Nb}$ & 10.66 & 13.06 & 13.40 & 16.05 & 14.47 & 14.74 & 16.37 & 16.40 & 17.39 & 10.46 & 14.92 & 15.17 \\
\hline Nd & 18.14 & 26.08 & 27.87 & 36.64 & 30.16 & 27.37 & 37.88 & 36.81 & 43.17 & 21.86 & 32.47 & 24.07 \\
\hline $\mathrm{Ni}$ & 18.09 & 12.21 & 8 & 15.22 & 35 & 33 & 14.83 & 19.92 & 27.10 & 13.59 & 13.23 & 10.18 \\
\hline $\mathrm{Pb}$ & 109.35 & 335.51 & 310.21 & 120.50 & 131.97 & 194.88 & 120 & 90.61 & 124 & 421.95 & 88 & 77.42 \\
\hline $\mathrm{Pr}$ & 4.59 & & 30 & 8 & 7.46 & 6.67 & 39 & 97 & 10.44 & 5.21 & 81 & 5.81 \\
\hline $\mathbf{R b}$ & 379.60 & 381.90 & 391.00 & 398.00 & 396.70 & 399.10 & 416.10 & 377.80 & 340.40 & 336.70 & 379.40 & 430.40 \\
\hline Sc & < D. L. & < D. L. & < D. L. & $<$ D. L. & < D. L. & <D. L. & $<$ D. L. & $<$ D. L. & <D. L. & < D. L. & < D. L. & < D. L. \\
\hline $\mathrm{Sb}$ & 1.10 & & & 3.17 & 3.30 & 3.17 & 3 & 2.13 & 5.9 & 4. & 2.76 & 1.56 \\
\hline Sm & 3.85 & 5.89 & & 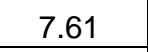 & 18 & 5.99 & . & 58 & 8.70 & 5.33 & 81 & 23 \\
\hline Sn & 20.05 & 20.02 & 16.76 & 1 & 23.17 & 19.95 & 16.47 & 16.96 & 16.21 & 15.95 & 25.06 & 24.40 \\
\hline $\mathrm{Sr}$ & 79.16 & 96.11 & 103.50 & 151.30 & 105.80 & 109.70 & 158.50 & 181.30 & 271.60 & 78.33 & 151.00 & 72.80 \\
\hline $\mathrm{Ta}$ & 2.38 & 2.97 & 2.73 & 2.66 & 2.88 & 3.00 & 2.67 & 2.70 & 2.72 & 2.11 & 2.80 & 3.69 \\
\hline $\mathrm{Tb}$ & 0.36 & 0.63 & & 09 & 61 & 0.64 & 0 & 0.70 & 0.90 & 0.60 & 0.65 & 0.49 \\
\hline Th & 14.10 & 17.03 & 19.48 & 22.78 & 20.98 & 19.22 & 23.47 & 21.16 & 19.74 & 14.76 & 19.14 & 18.63 \\
\hline $\mathrm{Tm}$ & 0.08 & 0.13 & 0.13 & 0.14 & 0.13 & 0.15 & 0.15 & 0.16 & 0.26 & 0.13 & 0.14 & 0.11 \\
\hline U & 77.65 & 212.50 & 292.40 & 214.30 & 217.10 & 233.20 & 239.30 & 171.70 & 228.40 & 205.90 & 202.70 & 88.83 \\
\hline V & 12.71 & 37.09 & 30.23 & 28.02 & 16.53 & 21.39 & 28.78 & 30.98 & 39.68 & 35.83 & 24.93 & 16.87 \\
\hline w & 402.40 & 47.91 & 20.17 & 18.53 & 14.91 & 20.05 & 17.54 & 19.60 & 37.12 & 50.02 & 18.17 & 14.32 \\
\hline$Y$ & 8.12 & 14.44 & 14.85 & 14.20 & 13.40 & 16.81 & 14.90 & 15.40 & 21.58 & 14.16 & 13.91 & 10.16 \\
\hline $\mathrm{Yb}$ & 0.55 & 0.83 & 0.82 & 0.90 & 0.82 & 0.95 & 0.95 & 1.01 & 1.63 & 0.80 & 0.87 & 0.66 \\
\hline $\mathrm{Zn}$ & 273.00 & 514.10 & 397.90 & 107.90 & 92.04 & 169.00 & 102.80 & 77.51 & 84.43 & 577.00 & 89.47 & 80.26 \\
\hline $\mathrm{Zr}$ & 79.63 & 113.00 & 115.30 & 156.60 & 120.10 & 114.30 & 161.30 & 180.00 & 221.00 & 91.85 & 143.80 & 95.01 \\
\hline
\end{tabular}




\begin{tabular}{|c|c|c|c|c|c|c|c|c|}
\hline & $\begin{array}{l}\text { BZN / 24.10- } \\
25.60 \mathrm{~m} / 2 \mathrm{~T}\end{array}$ & $\begin{array}{l}\text { BZN / 25.60- } \\
27.10 \mathrm{~m} / 3 \mathrm{~T}\end{array}$ & $\begin{array}{l}\text { BZN / 28.60- } \\
30.10 \mathrm{~m} / 2 \mathrm{~T}\end{array}$ & $\begin{array}{l}\text { BZN / 31.60- } \\
33.10 \mathrm{~m} / 2 \mathrm{~T}\end{array}$ & $\begin{array}{l}\text { BZN / 34.60- } \\
36.10 \mathrm{~m} / 1 \mathrm{~T}\end{array}$ & $\begin{array}{l}\text { BZN / 36.10- } \\
37.60 \mathrm{~m} / 1 \mathrm{~T}\end{array}$ & $\begin{array}{l}\text { BZN / 37.60- } \\
38.70 \mathrm{~m} / 2 \mathrm{~T}\end{array}$ & $\begin{array}{l}\text { BZN / 37.60- } \\
38.70 \mathrm{~m} / 3 \mathrm{~T}\end{array}$ \\
\hline As & 89.70 & 80.31 & 111.90 & 107.30 & 136.50 & 86.91 & 154.00 & 110.40 \\
\hline $\mathrm{Ba}$ & 317.50 & 505.00 & 711.70 & 697.40 & 750.80 & 532.10 & 2502.00 & 752.60 \\
\hline $\mathrm{Be}$ & 20.72 & 20.73 & 19.48 & 18.80 & 19.76 & 19.42 & 19.34 & 17.14 \\
\hline $\mathrm{Bi}$ & 6.06 & 4.49 & 3.88 & 2.98 & 2.41 & 5.89 & 3.89 & 3.14 \\
\hline $\mathrm{Cd}$ & 0.31 & 0.19 & 0.28 & 0.35 & 0.21 & 0.44 & 0.19 & 0.29 \\
\hline $\mathrm{Ce}$ & 52.47 & 54.69 & 61.96 & 69.74 & 70.16 & 53.80 & 75.07 & 65.74 \\
\hline Co & 4.58 & 3.81 & 5.64 & 5.55 & 4.83 & 5.25 & 8.09 & 4.83 \\
\hline $\mathrm{Cr}$ & 17.76 & 14.99 & 39.36 & 42.68 & 49.87 & 24.23 & 59.48 & 30.81 \\
\hline Cs & 28.41 & 26.77 & 43.35 & 33.85 & 39.18 & 30.38 & 42.55 & 30.79 \\
\hline $\mathrm{Cu}$ & 45.66 & 41.23 & 36.78 & 26.83 & 22.93 & 46.31 & 42.34 & 23.38 \\
\hline Dy & 2.57 & 2.21 & 3.10 & 3.59 & 3.53 & 2.20 & 4.32 & 2.96 \\
\hline $\mathrm{Er}$ & 0.97 & 0.78 & 1.18 & 1.38 & 1.32 & 0.77 & 1.78 & 1.09 \\
\hline Eu & 0.53 & 0.46 & 0.85 & 0.94 & 0.91 & 0.56 & 1.18 & 0.75 \\
\hline Ga & 24.28 & 25.65 & 26.54 & 25.87 & 25.79 & 25.13 & 25.03 & 26.01 \\
\hline Gd & 4.00 & 3.64 & 4.55 & 5.34 & 5.51 & 3.52 & 5.91 & 4.72 \\
\hline $\mathrm{Ge}$ & 2.00 & 2.28 & 2.43 & 2.27 & 2.50 & 2.01 & 2.71 & 2.64 \\
\hline $\mathrm{Hf}$ & 2.88 & 3.39 & 4.08 & 4.45 & 3.86 & 3.04 & 4.92 & 4.23 \\
\hline Ho & 0.39 & 0.33 & 0.48 & 0.56 & 0.55 & 0.32 & 0.71 & 0.45 \\
\hline In & 0.14 & 0.14 & 0.12 & 0.14 & 0.12 & 0.16 & 0.12 & 0.11 \\
\hline La & 23.95 & 25.70 & 32.45 & 34.64 & 34.13 & 25.42 & 42.30 & 32.05 \\
\hline Lu & 0.11 & 0.09 & 0.14 & 0.16 & 0.15 & 0.09 & 0.22 & 0.13 \\
\hline Mo & 0.50 & 0.53 & 0.57 & 0.65 & 0.76 & 0.87 & 1.41 & 0.59 \\
\hline $\mathrm{Nb}$ & 15.76 & 16.33 & 16.00 & 16.29 & 14.88 & 15.16 & 17.31 & 15.91 \\
\hline Nd & 25.34 & 26.06 & 29.48 & 33.72 & 33.86 & 26.34 & 35.67 & 31.45 \\
\hline $\mathrm{Ni}$ & 9.62 & 8.14 & 13.35 & 15.53 & 12.99 & 9.95 & 20.56 & 11.15 \\
\hline $\mathrm{Pb}$ & 71.92 & 72.79 & 106.93 & 109.69 & 78.38 & 106.83 & 109.42 & 109.96 \\
\hline $\mathrm{Pr}$ & 6.10 & 6.41 & 7.23 & 8.13 & 8.20 & 6.40 & 8.64 & 7.53 \\
\hline $\mathbf{R b}$ & 440.10 & 446.80 & 412.50 & 401.70 & 402.30 & 450.10 & 390.30 & 413.50 \\
\hline Sc & $<$ D. L. & < D. L. & $<$ D. L. & < D. L. & < D. L. & < D. L. & $<$ D. L. & $<$ D. L. \\
\hline Sb & 1.49 & 1.68 & 2.35 & 2.31 & 1.93 & 2.43 & 5.93 & 2.56 \\
\hline Sm & 5.63 & 5.62 & 6.37 & 7.31 & 7.46 & 5.49 & 7.75 & 6.65 \\
\hline Sn & 24.67 & 23.21 & 24.43 & 21.03 & 21.45 & 24.38 & 23.29 & 18.25 \\
\hline $\mathrm{Sr}$ & 73.86 & 75.72 & 132.80 & 138.00 & 125.40 & 82.83 & 205.50 & 127.20 \\
\hline $\mathrm{Ta}$ & 4.03 & 3.61 & 3.13 & 3.12 & 2.99 & 3.64 & 3.12 & 2.77 \\
\hline $\mathrm{Tb}$ & 0.55 & 0.48 & 0.65 & 0.75 & 0.75 & 0.48 & 0.86 & 0.65 \\
\hline Th & 20.33 & 21.58 & 18.11 & 22.23 & 22.62 & 19.28 & 19.24 & 22.86 \\
\hline $\mathrm{Tm}$ & 0.13 & 0.11 & 0.16 & 0.18 & 0.18 & 0.10 & 0.25 & 0.14 \\
\hline$U$ & 101.30 & 106.10 & 116.90 & 103.70 & 140.10 & 161.70 & 163.90 & 111.90 \\
\hline $\mathbf{v}$ & 15.96 & 17.11 & 23.51 & 23.62 & 23.17 & 15.38 & 30.75 & 20.74 \\
\hline w & 24.52 & 24.13 & 23.53 & 18.22 & 13.17 & 18.78 & 32.36 & 14.32 \\
\hline $\mathrm{Y}$ & 12.61 & 10.15 & 14.88 & 17.64 & 17.14 & 9.90 & 22.53 & 13.87 \\
\hline $\mathrm{Yb}$ & 0.84 & 0.67 & 0.98 & 1.11 & 1.06 & 0.65 & 1.56 & 0.88 \\
\hline $\mathrm{Zn}$ & 79.37 & 73.36 & 86.52 & 123.10 & 75.55 & 105.40 & 77.83 & 102.90 \\
\hline $\mathrm{Zr}$ & 94.98 & 112.60 & 145.10 & 157.20 & 137.30 & 104.70 & 180.90 & 148.70 \\
\hline
\end{tabular}


Table SI-6. Elemental correlations calculated from the chemical and radiological characterizations of the mill tailings.

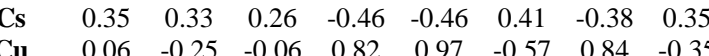

$\begin{array}{lllllllllll}\text { Cu } & 0.06 & -0.25 & -0.06 & 0.82 & 0.97 & -0.57 & 0.84 & -0.35 & -0.53\end{array}$

$\begin{array}{lllllllllll}\text { Dy } & 0.57 & 0.84 & -0.01 & -0.23 & -0.16 & 0.82 & 0.26 & 0.86 & 0.48 & -0.24\end{array}$

$\begin{array}{llllllllllll}\text { Er } & 0.50 & 0.87 & -0.05 & -0.28 & -0.22 & 0.79 & 0.21 & 0.87 & 0.50 & -0.28 & 0.99\end{array}$

$\begin{array}{lllll}0.92 & 0.32 & -0.16 & 0.94 & 0.92\end{array}$

$\begin{array}{llllllllllllll}\text { Ga } & 0.42 & -0.09 & 0.59 & -0.36 & -0.37 & 0.30 & -0.55 & -0.16 & 0.58 & -0.52 & 0.06 & 0.02 & -0.08\end{array}$

$\begin{array}{lllllllllllllll}\text { Gd } & 0.68 & 0.76 & 0.14 & -0.26 & -0.15 & 0.89 & 0.21 & 0.80 & 0.46 & -0.28 & 0.96 & 0.91 & 0.91 & 0.24\end{array}$

$\begin{array}{lllllllllllllllll}\text { Ge } & 0.84 & 0.23 & 0.59 & -0.10 & 0.05 & 0.43 & 0.00 & 0.06 & 0.49 & -0.12 & 0.39 & 0.31 & 0.32 & 0.73 & 0.56\end{array}$

$\begin{array}{llllllllllllllllll}\text { Hf } & 0.37 & 0.82 & -0.06 & -0.48 & -0.46 & 0.96 & -0.02 & 0.88 & 0.42 & -0.53 & 0.87 & 0.86 & 0.88 & 0.18 & 0.87 & 0.34\end{array}$

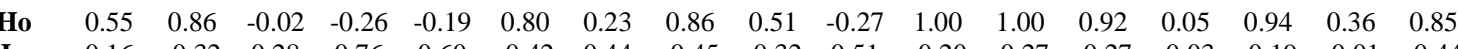

$\begin{array}{llllllllllllllllll}0.16 & -0.32 & 0.28 & 0.76 & 0.60 & -0.42 & 0.44 & -0.45 & -0.32 & 0.51 & -0.20 & -0.27 & -0.27 & -0.03 & -0.19 & -0.01 & -0.44 & -0.23\end{array}$

$\begin{array}{lllllllllllllllllll}0.43 & 0.86 & 0.00 & -0.48 & -0.45 & 0.98 & -0.02 & 0.90 & 0.43 & -0.52 & 0.88 & 0.87 & 0.90 & 0.18 & 0.89 & 0.36 & 0.98 & 0.86 & -0.45\end{array}$

$\begin{array}{llllllllllllllllllll}0.45 & 0.90 & -0.10 & -0.29 & -0.24 & 0.77 & 0.20 & 0.87 & 0.49 & -0.28 & 0.96 & 0.99 & 0.91 & -0.06 & 0.86 & 0.26 & 0.84 & 0.98 & -0.32 & 0.86\end{array}$

$\begin{array}{llllllllllllllllllllllll}0.52 & 0.81 & -0.04 & -0.15 & -0.10 & 0.51 & 0.28 & 0.60 & 0.20 & -0.09 & 0.63 & 0.64 & 0.65 & -0.12 & 0.55 & 0.24 & 0.50 & 0.64 & -0.13 & 0.60 & 0.68 \\ 0.09 & 0.56 & 0.09 & -0.52 & -0.76 & 0.75 & -0.45 & 0.55 & 0.47 & -0.82 & 0.56 & 0.58 & 0.65 & 0.41 & 0.56 & 0.18 & 0.77 & 0.57 & -0.28 & 0.74 & 0.56\end{array}$ $\begin{array}{lllllllllllllllllllllll}0.09 & 0.56 & 0.09 & -0.52 & -0.76 & 0.75 & -0.45 & 0.55 & 0.47 & -0.82 & 0.56 & 0.58 & 0.46 & 0.41 & 0.56 & 0.18 & 0.77 & 0.57 & -0.28 & 0.74 & 0.56 & 0.25 \\ 0.47 & 0.76 & 0.08 & -0.49 & -0.46 & 1.00 & -0.07 & 0.84 & 0.41 & -0.56 & 0.84 & 0.81 & 0.86 & 0.29 & 0.90 & 0.43 & 0.96 & 0.81 & -0.38 & 0.98 & 0.77 & 0.51\end{array}$ $\begin{array}{llllllllllllllllllllll}0.05 & 0.76 & -0.37 & -0.24 & -0.12 & 0.59 & 0.34 & 0.86 & 0.02 & -0.06 & 0.64 & 0.67 & 0.80 & -0.49 & 0.53 & -0.19 & 0.67 & 0.64 & -0.50 & 0.69 & 0.72\end{array}$

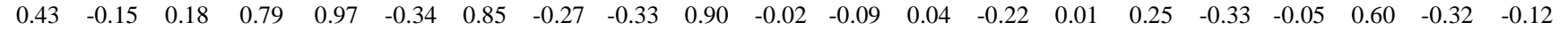

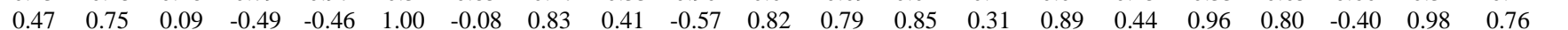

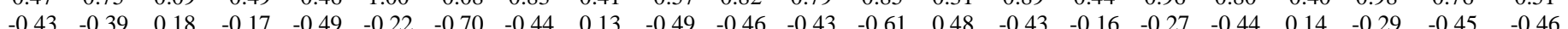

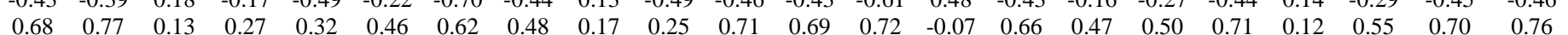
$\begin{array}{llllllllllllllllllllll}0.54 & 0.76 & 0.10 & -0.41 & -0.37 & 0.97 & 0.01 & 0.84 & 0.44 & -0.49 & 0.90 & 0.86 & 0.88 & 0.29 & 0.95 & 0.48 & 0.94 & 0.87 & -0.29 & 0.95 & 0.81 & 0.0\end{array}$

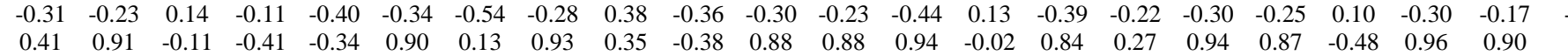

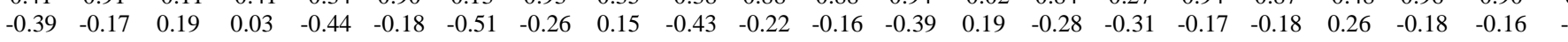
$\begin{array}{llllllllllllllllllllll}0.64 & 0.80 & 0.07 & -0.23 & -0.14 & 0.85 & 0.25 & 0.83 & 0.48 & -0.25 & 0.99 & 0.96 & 0.93 & 0.16 & 0.99 & 0.49 & 0.87 & 0.97 & -0.18 & 0.88 & 0.92 & 0.55 \\ 0.18 & 0.19 & 0.17 & -0.54 & -0.60 & 0.66 & -0.53 & 0.28 & 0.30 & -0.73 & 0.35 & 0.31 & 0.23 & 0.65 & 0.50 & 0.40 & 0.56 & 0.32 & -0.20 & 0.54 & 0.23 & -0.0\end{array}$ $\begin{array}{llllllllllllllllllllll}0.18 & 0.19 & 0.17 & -0.54 & -0.60 & 0.66 & -0.53 & 0.28 & 0.30 & -0.73 & 0.35 & 0.31 & 0.23 & 0.65 & 0.50 & 0.40 & 0.56 & 0.32 & -0.20 & 0.54 & 0.23 \\ 0.45 & 0.89 & -0.09 & -0.27 & -0.24 & 0.77 & 0.21 & 0.87 & 0.48 & -0.28 & 0.97 & 0.99 & 0.90 & -0.04 & 0.88 & 0.25 & 0.84 & 0.99 & -0.27 & 0.85 & 0.99 & 0 . \\ 0.80 & 0.31 & 0.43 & 0.25 & 0.39 & 0.35 & 0.45 & 0.12 & 0.04 & 0.27 & 0.36 & 0.27 & 0.43 & 0.29 & 0.50 & 0.70 & 0.24 & 0.31 & 0.25 & 0.31 & 0.22 & 0 .\end{array}$ $\begin{array}{llllllllllllllllllllll}0.80 & 0.31 & 0.43 & 0.25 & 0.39 & 0.35 & 0.45 & 0.12 & 0.04 & 0.27 & 0.36 & 0.27 & 0.43 & 0.29 & 0.50 & 0.70 & 0.24 & 0.31 & 0.25 & 0.31 & 0.22 \\ \end{array}$ $\begin{array}{llllllllllllllllllllll}0.60 & 0.58 & 0.15 & 0.37 & 0.48 & 0.50 & 0.78 & 0.58 & -0.02 & 0.38 & 0.69 & 0.62 & 0.79 & -0.20 & 0.70 & 0.35 & 0.53 & 0.65 & 0.15 & 0.54 & 0.59 \\ 0\end{array}$ $\begin{array}{lllllllllllllllllllll}-0.49 & -0.18 & -0.37 & -0.07 & 0.13 & -0.44 & 0.05 & -0.16 & -0.31 & 0.33 & -0.43 & -0.36 & -0.29 & -0.51 & -0.52 & -0.48 & -0.40 & -0.39 & -0.42 & -0.36 & -0.28\end{array}$ $\begin{array}{lllllllllllllllllllll}0.62 & 0.81 & 0.04 & -0.17 & -0.08 & 0.72 & 0.30 & 0.77 & 0.51 & -0.16 & 0.98 & 0.98 & 0.88 & 0.07 & 0.92 & 0.42 & 0.77 & 0.98 & -0.15 & 0.78 & 0.95 \\ 0.45 & 0.90 & -0.08 & -0.26 & -0.24 & 0.77 & 0.22 & 0.87 & 0.46 & -0.28 & 0.97 & 0.99 & 0.91 & -0.05 & 0.87 & 0.25 & 0.84 & 0.98 & -0.29 & 0.86 & 0.99\end{array}$

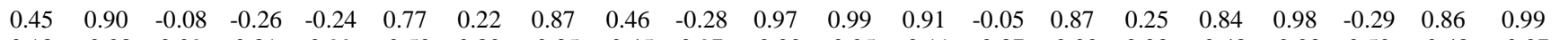
$\begin{array}{ccccccccccccccccccccc}0.18 & -0.28 & 0.09 & 0.81 & 0.99 & -0.50 & 0.82 & -0.35 & -0.45 & 0.97 & -0.20 & -0.25 & -0.11 & -0.37 & -0.20 & 0.03 & -0.48 & -0.23 & 0.52 & -0.48 & -0.27 \\ 0.37 & 0.84 & -0.08 & -0.46 & -0.41 & 0.96 & 0.04 & 0.91 & 0.39 & -0.48 & 0.87 & 0.87 & 0.91 & 0.12 & 0.87 & 0.31 & 1.00 & 0.86 & -0.44 & 0.98 & 0.86\end{array}$ $\begin{array}{llllllllllllllllllllll}0.37 & 0.84 & 0.08 & -0.46 & 0.41 & 0.96 & 0.04 & 0.91 & 0.39 & -9.48 & 0.87 & 0.87 & 0.91 & 0.12 & 0.87 & 0.31 & 1.00 & 0.86 & -0.44 & 0.98 & 0.86 & 0.54 \\ 0.55 & 0.11 & 0.34 & 0.09 & 0.24 & 0.22 & 0.26 & -0.01 & -0.17 & 0.20 & 0.11 & 0.04 & 0.19 & 0.23 & 0.26 & 0.46 & 0.06 & 0.08 & 0.06 & 0.15 & -0.03 & 0.23\end{array}$

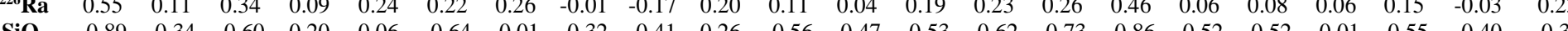

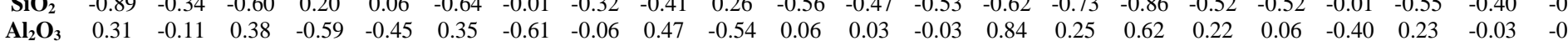

\begin{tabular}{llllllllllllllllllllllll}
$\mathrm{Fe}_{2} \mathrm{O}_{3}$ & 0.91 & 0.51 & 0.48 & -0.15 & 0.01 & 0.70 & 0.17 & 0.46 & 0.43 & -0.16 & 0.73 & 0.66 & 0.70 & 0.46 & 0.85 & 0.83 & 0.63 & 0.70 & -0.07 & 0.67 & 0.61 & 0.46 \\
\hline
\end{tabular}

$\begin{array}{llllllllllllllllllllllll}\text { MnO } & 0.79 & 0.05 & 0.68 & 0.14 & 0.32 & 0.19 & 0.21 & -0.07 & 0.22 & 0.18 & 0.24 & 0.17 & 0.23 & 0.48 & 0.40 & 0.75 & 0.07 & 0.22 & 0.15 & 0.13 & 0.10 & 0.70 .78 \\ \text { MgO } & 0.75 & 0.63 & 0.28 & -0.40 & -0.20 & 0.83 & 0.06 & 0.68 & 0.50 & -0.34 & 0.79 & 0.75 & 0.80 & 0.38 & 0.88 & 0.66 & 0.78 & 0.78 & -0.33 & 0.81 & 0.71 & 0.30\end{array}$

$\begin{array}{ccccccccccccccccccccccc}\mathbf{C a O} & 0.86 & 0.17 & 0.62 & 0.07 & 0.18 & 0.42 & 0.20 & 0.17 & 0.21 & -0.02 & 0.44 & 0.34 & 0.41 & 0.44 & 0.60 & 0.71 & 0.29 & 0.39 & 0.30 & 0.33 & 0.26 & 0.35\end{array}$

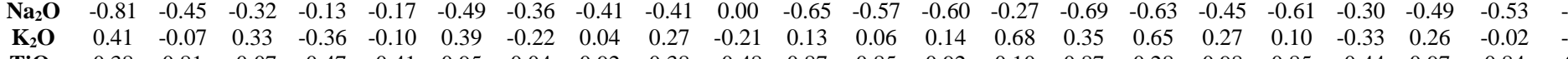

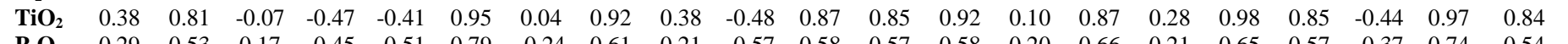

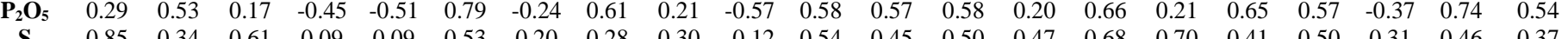

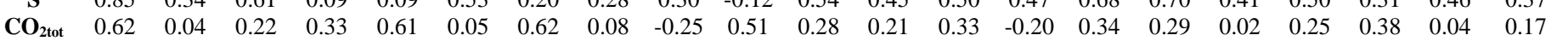
$\begin{array}{llllllllllllllllllllll}\text { TOC } & 0.44 & 0.57 & 0.05 & -0.08 & 0.03 & 0.44 & 0.24 & 0.36 & 0.01 & 0.03 & 0.50 & 0.50 & 0.53 & -0.07 & 0.49 & 0.33 & 0.42 & 0.50 & -0.23 & 0.49 & 0.53 \\ \end{array}$

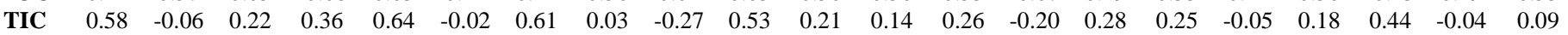
\begin{tabular}{llllllllllllllllllllllll}
$\mathbf{H}_{2} \mathbf{O}$ & 0.81 & 0.43 & 0.48 & -0.23 & -0.18 & 0.63 & -0.03 & 0.38 & 0.45 & -0.36 & 0.58 & 0.51 & 0.53 & 0.52 & 0.71 & 0.73 & 0.53 & 0.55 & 0.08 & 0.57 & 0.46 & 0.5 \\
\hline
\end{tabular} $\begin{array}{ccccccccccccccccccccccc}\text { LOI } & 0.86 & 0.40 & 0.51 & -0.13 & -0.06 & 0.60 & 0.08 & 0.36 & 0.38 & -0.25 & 0.58 & 0.51 & 0.54 & 0.47 & 0.72 & 0.74 & 0.50 & 0.55 & 0.16 & 0.53 & 0.45 & 0.49 \\ \text { Total } & 0.59 & 0.38 & 0.18 & -0.43 & -0.30 & 0.61 & -0.12 & 0.42 & 0.45 & -0.40 & 0.62 & 0.60 & 0.51 & 0.39 & 0.70 & 0.48 & 0.53 & 0.62 & -0.15 & 0.56 & 0.52 & 0.35\end{array}$

0.75

$0.25 \quad 0.58$

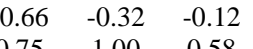

$\begin{array}{llll}0.75 & 1.00 & 0.58 & -0.32\end{array}$

$\begin{array}{lllll}0.36 & -0.22 & -0.62 & -0.55 & -0.22\end{array}$

$\begin{array}{llllll}0.72 & 0.98 & 0.55 & -0.22 & 0.47 & -0.59 \\ 0.16 & -0.33 & -0.41 & -0.46 & -0.34 & 0.58\end{array}$

$\begin{array}{llll}0.16 & -0.33 & -0.41 & -0.46\end{array}$

0.60

0.45

0.56

0.74

$\begin{array}{cc}0.59 & 0.78 \\ -0.07 & 0.36\end{array}$

$\begin{array}{lll}-0.07 & 0.36 & 0.06\end{array}$

$\begin{array}{lll}0.06 & 0.51 & 0.5 \\ -0.59 & -0.48 & 0.26\end{array}$

$\begin{array}{lll}0.47 & 0.73 & 0.57\end{array}$

$\begin{array}{lll}0.58 & 0.78 & 0.51\end{array}$

$\begin{array}{lll}-0.80 & -0.49 & -0.10 \\ 0.72 & 0.95 & 0.72\end{array}$

$\begin{array}{lll}-0.14 & 0.21 & 0.02\end{array}$

$\begin{array}{lll}-0.34 & -0.65 & -0.03\end{array}$

$\begin{array}{lll}0.30 & 0.33 & -0.28 \\ 0.35 & 0.71 & 0.23\end{array}$

$\begin{array}{lll}-0.14 & 0.19 & -0.15 \\ 0.46 & 0.83 & 0.55\end{array}$

$\begin{array}{ccc}0.13 & 0.45 & -0.05\end{array}$

\begin{tabular}{lll}
-0.26 & -0.52 & -0.11 \\
\hline & 0.36 & -0.12
\end{tabular}

$\begin{array}{lll}0.11 & 0.36 & -0.12\end{array}$

$\begin{array}{lll}0.71 & 0.95 & 0.73 \\ 0.61 & 0.79 & 0.44\end{array}$

$\begin{array}{lll}0.61 & 0.79 & 0.44 \\ 0.33 & 0.56 & 0.01\end{array}$

$\begin{array}{llll}0.41 & 0.33 & 0.56 & 0.0 \\ 0.25 & -0.37 & 0.08 & 0.12\end{array}$

$\begin{array}{llll}0.25 & -0.37 & 0.08 & 0.12 \\ 0.59 & 0.11 & 0.44 & 0.42\end{array}$

$\begin{array}{ccc}0.11 & 0.44 & 0.42 \\ -0.41 & 0.01 & 0.06 \\ 0.45 & 0.65 & 0.06\end{array}$

$\begin{array}{ccc}-0.41 & 0.01 & 0.06 \\ 0.45 & 0.65 & 0.06\end{array}$

$\begin{array}{lll}0.38 & 0.62 & 0.06 \\ 0.43 & 0.62 & 0.18\end{array}$

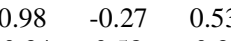

$\begin{array}{ccccc}-0.22 & 0.89 & -0.48 & -0.39 & -0.33 \\ -0.50 & -0.17 & 0.81 & -0.36 & -0.17\end{array}$

$\begin{array}{llll}-0.50 & -0.17 & 0.81 & -0.36 \\ 0.01 & -0.85 & -0.44 & 0.70\end{array}$

$\begin{array}{llll}-0.01 & 0.85 & -0.44 & 0.70\end{array}$

$\begin{array}{cccc}-0.51 & 0.67 & 0.41 & -0.09 \\ -0.12 & 0.76 & -0.42 & 0.69 \\ 0.56 & 0.37 & -0.45 & 0.67\end{array}$

$\begin{array}{llll}0.56 & 0.37 & -0.45 & 0.67\end{array}$

$\begin{array}{llll}0.56 & 0.50 & -0.72 & 0.78\end{array}$

$\begin{array}{llll}0.00 & -0.46 & -0.22 & -0.25 \\ 0.07 & 0.72 & -0.48 & 0.75\end{array}$

$\begin{array}{llll}0.07 & 0.72 & -0.48 & 0.75 \\ -0.12 & 0.77 & -0.43 & 0.71 \\ 0.95 & -0.49 & -0.50 & 0.28\end{array}$

$\begin{array}{llll}-0.12 & 0.77 & -0.43 & 0.71 \\ 0.95 & -0.49 & -0.50 & 0.28\end{array}$

$\begin{array}{llll}-0.29 & 0.95 & -0.34 & 0.53\end{array}$

$\begin{array}{cccc}-0.14 & -0.65 & 0.25 & -0.46 \\ -0.32 & 0.35 & 0.26 & -0.21\end{array}$

$-0.32 \quad 0.35$

0.49

$\begin{array}{rr}-0.01 & 0.83 \\ 0.34 & 0.44\end{array}$

$\begin{array}{cc}0.34 & 0.44 \\ -0.34 & -0.51 \\ 0.01 & 0.39\end{array}$

0.01
-0.29

$\begin{array}{ll}-0.45 \quad 0.79 \\ 0.25 & 0.55\end{array}$

$0.25 \quad 0.55$

$\begin{array}{ll}0.69 & 0.06 \\ 0.16 & 0.45\end{array}$

$\begin{array}{ll}0.16 & 0.45 \\ 0.71 & -0.0 \\ 0.01 & 0.64\end{array}$

0.01
0.12

$\begin{array}{ll}0.12 & 0.61 \\ -0.14 & 0\end{array}$ $\begin{array}{ll}0.87 & -0.35 \\ -0.17 & 0.73\end{array}$

$\begin{array}{ccc}0.87 & -0.35 & \\ 0.17 & 0.73 & -0.31 \\ 0.93 & -0.35 & 0.86 \\ 0.65 & -0.09 & 0.31\end{array}$

$\begin{array}{lll}0.65 & -0.09 & 0.31\end{array}$

$\begin{array}{lll}0.83 & -0.18 & 0.88\end{array}$

$\begin{array}{lll}0.38 & -0.53 & 0.32 \\ 0.58 & -0.63 & 0.61\end{array}$

$\begin{array}{lll}-0.55 & -0.07 & -0.20\end{array}$

$\begin{array}{lll}0.81 & -0.27 & 0.80 \\ 0.82 & -0.20 & 0.89\end{array}$

$\begin{array}{lll}0.82 & -0.20 & 0.89 \\ -0.41 & -0.41 & -0.36\end{array}$

$\begin{array}{lll}0.94 & -0.33 & -0.36\end{array}$

$\begin{array}{lll}0.920 & -0.61 & 0.16\end{array}$

$\begin{array}{lll}-0.69 & 0.29 & -0.46\end{array}$

$\begin{array}{lll}0.30 & -0.11 & 0.08 \\ 0.76 & -0.40 & 0.62\end{array}$

$\begin{array}{lll}0.76 & -0.40 & 0.62 \\ 0.24 & -0.36 & 0.12\end{array}$

$\begin{array}{lll}0.85 & -0.44 & 0.79\end{array}$

$\begin{array}{lll}0.52 & -0.27 & 0.27\end{array}$

$\begin{array}{ccc}-0.61 & 0.16 & -0.44 \\ 0.35 & -0.49 & 0.15 \\ 0.93 & -0.35 & 0.96\end{array}$

$\begin{array}{lll}0.93 & -0.35 & 0.96\end{array}$

$\begin{array}{lll}0.76 & -0.19 & 0.65 \\ 0.62 & -0.20 & 0.38\end{array}$

$\begin{array}{lll}0.62 & -0.20 & 0.38 \\ 0.17 & -0.49 & 0.12\end{array}$

$\begin{array}{lll}0.62 & -0.20 & 0.38 \\ 0.17 & -0.49 & 0.12 \\ 0.43 & -0.42 & 0.56\end{array}$

$\begin{array}{lll}0.10 & -0.45 & 0.03 \\ 0.70 & -0.07 & 0.48\end{array}$

$\begin{array}{lll}0.70 & -0.07 & 0.48 \\ 0.68 & -0.14 & 0.46 \\ 0.66 & -0.17 & 0.51\end{array}$ $\begin{array}{lll}0.68 & -0.14 & 0.46 \\ 0.66 & -0.17 & 0.51\end{array}$ 


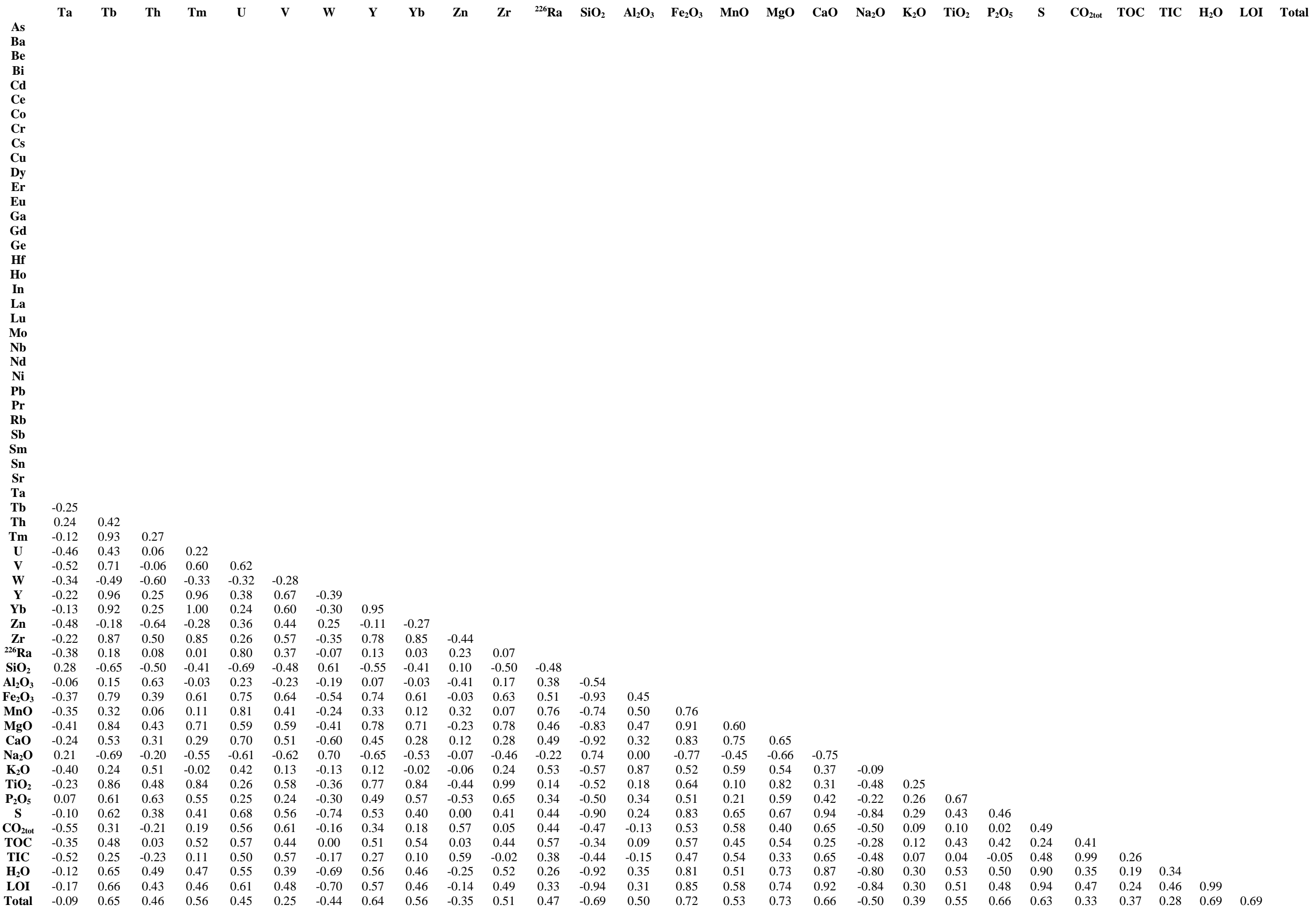

